ENGINEERING CHANGE NOTICE

\begin{tabular}{|c|c|c|c|c|c|c|}
\hline \multirow{3}{*}{$\begin{array}{l}\text { 2. ECN Category } \\
\text { (mark one) } \\
\text { supplemental } \\
\text { Direct Revision } \\
\text { Change ECN } \\
\text { Temporary } \\
\text { Standby } \\
\text { Supersedure } \\
\text { Cancel/Noid }\end{array}$} & \multirow{3}{*}{$\begin{array}{r}{[1} \\
{[x]} \\
{[]} \\
{[]} \\
{[]} \\
{[]} \\
{[]}\end{array}$} & \multicolumn{2}{|c|}{$\begin{array}{l}\text { 3. Originator's Name, Organization, MSIN, } \\
\text { and Telephone No. } \\
\text { S A Krieg NUMATEC 376-0971 } \\
\text { H6-12 }\end{array}$} & \multicolumn{2}{|c|}{$\begin{array}{l}\text { 4. USQ Required? } \\
\text { [] Yes }[\mathrm{X}] \text { No }\end{array}$} & $\begin{array}{l}\text { 5. Date } \\
7 / 9 / 98\end{array}$ \\
\hline & & \multicolumn{2}{|c|}{$\begin{array}{c}\text { 6. Project Title/No./Work Order No. } \\
\text { HTI/D25E4 }\end{array}$} & \multicolumn{2}{|c|}{$\begin{array}{c}\text { 7. Bldg./Sys./Fac. No. } \\
\text { NA }\end{array}$} & $\begin{array}{c}\text { 8. Approval Designator } \\
\text { NA }\end{array}$ \\
\hline & & \multicolumn{2}{|c|}{$\begin{array}{l}\text { 9. Document Numbers Changed by this ECN } \\
\text { (includes sheet no. and rev.) } \\
\text { HNF-2693 Revision } 0\end{array}$} & \multicolumn{2}{|c|}{$\begin{array}{l}\text { 10. Related ECN No(s). } \\
\text { NA }\end{array}$} & $\begin{array}{c}\text { 11. Related Po No. } \\
\text { NA }\end{array}$ \\
\hline \multirow{2}{*}{\multicolumn{2}{|c|}{$\begin{array}{l}\text { 12a. Modification Work } \\
\text { [] Yes (fill out Blk. } \\
12 \mathrm{~b} \text { ) } \\
\text { [X] No (NA Blks. 12b, } \\
12 \mathrm{c}, 12 \mathrm{~d} \text { ) }\end{array}$}} & \multirow[t]{2}{*}{$\begin{array}{l}\text { 12b. Work Package } \\
\text { No. } \\
\text { NA }\end{array}$} & \multirow{2}{*}{\multicolumn{2}{|c|}{$\begin{array}{l}\text { 12c. Modification Work Complete } \\
\text { NA } \\
\begin{array}{l}\text { Design Authority/Cog. Engineer } \\
\text { Signature \& Date }\end{array}\end{array}$}} & \multicolumn{2}{|c|}{$\begin{array}{l}\text { 12d. Restored to Original Condi- } \\
\text { tion (Temp. or Standby ECN only) } \\
\text { NA }\end{array}$} \\
\hline & & & & & Design A & $\begin{array}{l}\text { ority/log. Ens } \\
\text { ature \& Date }\end{array}$ \\
\hline
\end{tabular}

14a. Justification (mark one)

$\begin{array}{lllllll}\text { Criteria Change } & {[\mathrm{X}]} & \text { Design Improvement } & {[]} & \text { Environmental } & {[]} & \text { Facility Deactivation } \\ \text { As-Found } & {[]} & \text { Facilitate Const } & {[]} & \text { Const. Error/Omission } & {[]} & \text { Design Error/Omission }\end{array}$

14b. Justification Details

New waste retrieval rates ( $t a b l e ~ A-5$ ) resulted in recalculation of data in study.

15. Distribution (include name, MSIN, and no. of copies)

See distribution sheet

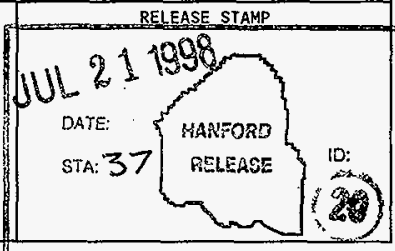




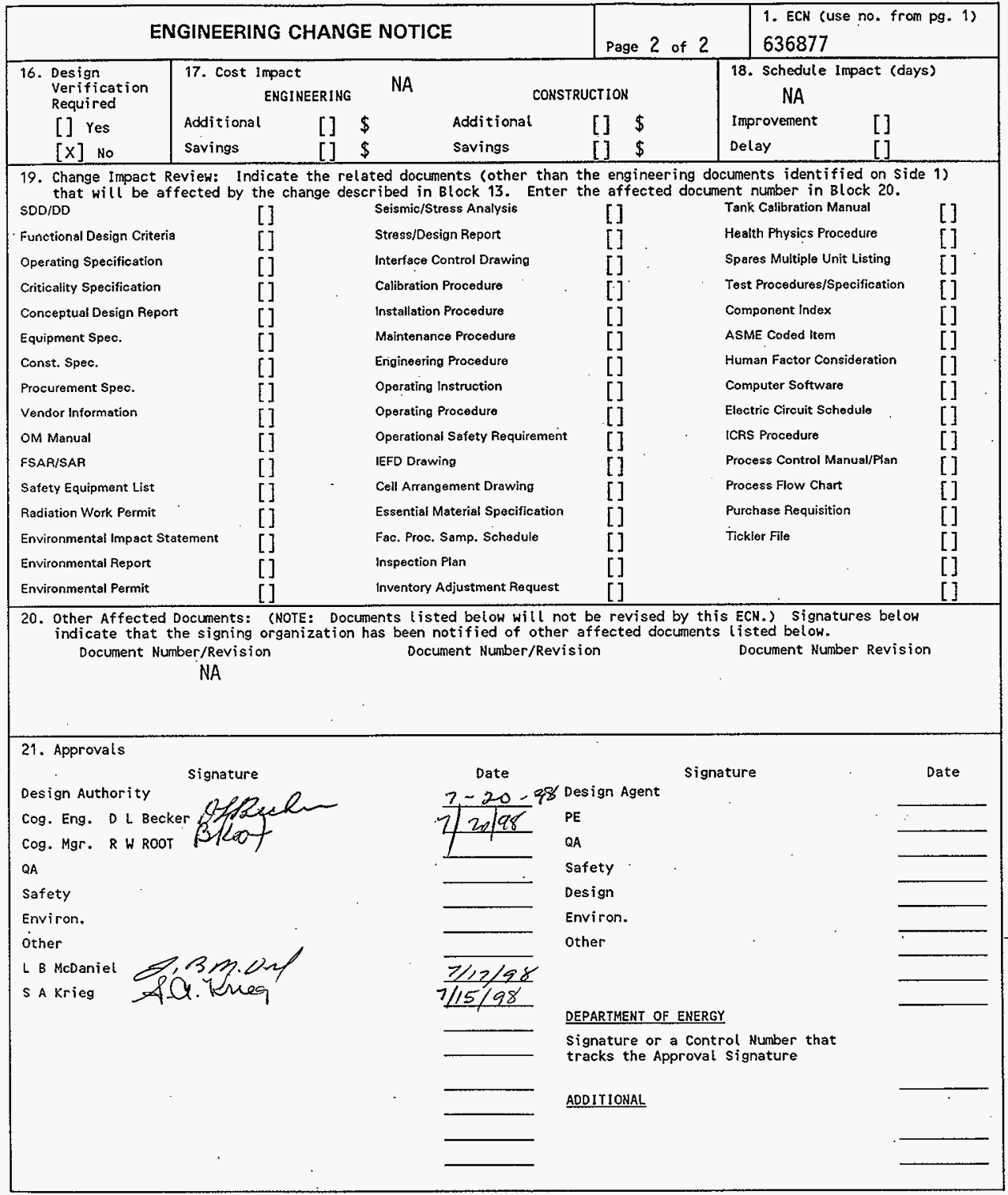


HNF-2693, Rev. 1

\section{AX Tank Farm Waste Retrieval Alternatives Cost Estimates}

\section{S. A. Krieg}

Numatec Hanford Corporation, Richland, WA 99352

U.S. Department of Energy Contract DE-ACO6-96RL13200

$\begin{array}{lll}\text { EDT/ECN: } & 636877 & \text { UC: } 721 \\ \text { Org Code: } 7 C 260 & \text { Charge Code: } & \text { D25E4 } \\ \text { B\&R Code: } & \text { EW3130010 } & \text { Total Pages: }\end{array}$

Key Words: Hanford Tanks Initiative, single-she11 tanks, retrieval

Abstract: This report presents the estimated costs associated with retrieval of the wastes from the four tanks in AX Tank Farm. The engineering cost estimates developed for this report are based on previous cost data prepared for Project $W-320$ and the HTI 241-C-106 Heel Retrieval System. The costs presented in this report address only the retrieval of the wastes from the four AX Farm tanks. This includes costs for equipment procurement, fabrication, installation, and operation to retrieve the wastes. The costs to modify the existing plant equipment and systems to support the retrieval equipment are also included. The estimates do not include operational costs associated with pumping the waste out of the waste receiver tank (241-AY-102) between AX Farm retrieval campaigns or transportation, processing, and disposal of the retrieved waste.

IRADEMARK DISCLAIMER, Reference herein to any specific commercial product, process, or service by trade name, trademark, manufacturer, or otherwise, does not necessarily constitute or imply its endorsement, recommendation, or favoring by the United States Government or any agency thereof or its contractors or subcontractors.

Printed in the United States of America. To obtain copies of this document, contact: Document Control Services, P.O. Box 950, Mailstop H6-08, Richland WA 99352, Phone (509) 372-2420; Fax (509) 376-4989.

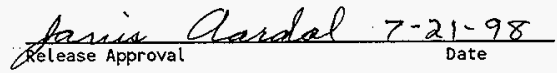

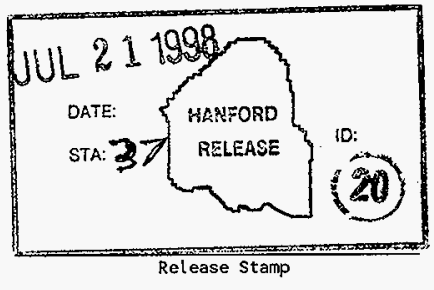




\section{RECORD OF REVISION}

(1) Document Number

HNF-2693

Page 1

(2) Title

AX Tank Farm Waste Retrieval Alternatives Cost Estimates

CHANGE CONTROL RECORD

(3)

Revision

0

1 RS
(4) Description of Change - Replace, Add, and Delete Pages (7). $\mathrm{ECN} 622716 \quad 5 / 21 / 98$

7/15/98 Complete revision per ECN 636877
Authorized for Release

(5) Cog. Engr. (6) Cog. Mgr. Date

Dificher RWO Root 
HNF-2693

Revision 1

\title{
AX TANK FARM WASTE RETRIEVAL ALTERNATIVES COST ESTIMATES
}

July 1998

\author{
S. A. Krieg \\ Numatec Hanford Corporation \\ Richland, Washington
}

Prepared for

U.S. Department of Energy

Richland, Washington 
HNF-2693

Revision 1

This page intentionally left blank. 
HNF-2693

Revision 1

CONTENTS

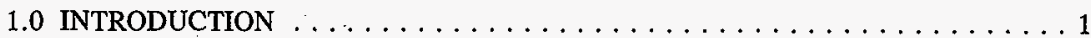

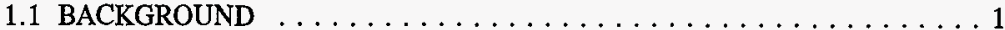

1.2 PURPOSE AND SCOPE $\ldots \ldots \ldots \ldots \ldots \ldots \ldots \ldots$

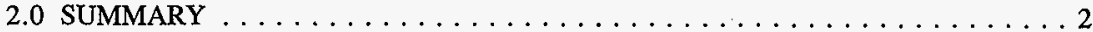

3.0 RETRIEVAL SYSTEMS DESCRIPTIONS $\ldots \ldots \ldots \ldots \ldots \ldots \ldots$

4.0 RISKS AND UNCERTAINTIES $\ldots \ldots \ldots \ldots \ldots \ldots \ldots \ldots$

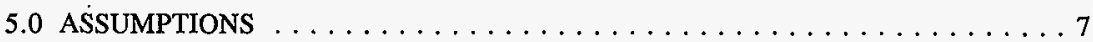

6.0 WASTE MEASUREMENT TECHNIQUES $\ldots \ldots \ldots \ldots \ldots \ldots$

7.0 REFERENCES $\ldots \ldots \ldots \ldots \ldots \ldots \ldots \ldots \ldots \ldots \ldots \ldots \ldots \ldots \ldots \ldots \ldots \ldots$

\section{LIST OF FIGURES}

1. AX Tank Farm Waste Process Flowchart. . . . . . . . . . . . . . 3

\section{LIST OF TABLES}

1. Tank Waste Retrieval Cost Summary Estimate For AX Farm $-\mathbf{K} \$ \ldots \ldots \ldots \ldots \ldots 4$

2. Estimated AY Farm Cost and Worker-Hour Breakdown (all 4 tanks) $\ldots \ldots \ldots \ldots 5$

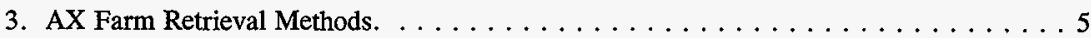


HNF-2693

Revision 1

\section{LIST OF TERMS}

$\begin{array}{ll}\text { ALC } & \text { Air lift circulator } \\ \text { BOP } & \text { Balance of Plant } \\ \text { CCTV } & \text { Closed-circuit television } \\ \text { D\&D } & \text { Decontamination and decommissioning } \\ \text { DOE } & \text { U.S. Department of Energy } \\ \text { DST } & \text { Double-shell tank } \\ \text { Ecology } & \text { Washington State Department of Ecology } \\ \text { EIS } & \text { Environmental Impact Statement } \\ \text { FDNW } & \text { Fluor Daniel Northwest } \\ \text { HTI } & \text { Hanford Tanks Initiative } \\ \text { HVAC } & \text { Heating, ventilating, and air conditioning } \\ \text { LLCE } & \text { Long-length contaminated equipment } \\ \text { ORR } & \text { Operational Readiness Review } \\ \text { PHMC } & \text { Project Hanford Management Contractor } \\ \text { PNNL } & \text { Pacific Northwest National Laboratory } \\ \text { PPS } & \text { Past-Practice Sluicing } \\ \text { ROM } & \text { Rough order of magnitude } \\ \text { RPECA } & \text { Retrieval Performance Evaluation Criteria Alternatives } \\ \text { TWRS } & \text { Tank Waste Remediation System }\end{array}$


HNF-2693

Revision 1

\section{AX TANK FARM WASTE RETRIEVAL ALTERNATIVES COST ESTIMATES}

\subsection{INTRODUCTION}

\subsection{BACKGROUND}

In 1996, the U.S. Department of Energy (DOE) implemented a five-year demonstration project known as the Hanford Tanks Initiative (HTI). The scope of HTI is to:

(1) demonstrate alternate retrieval technologies for tank waste; (2) retrieve hard-heel waste from tank 241-C-106 and assess compliance with retrieval performance evaluation criteria for that activity; (3) characterize residual waste in tank 241-AX-104 and assess compliance with retrieval performance criteria for that tank; and (4) develop retrieval performance evaluation criteria supporting readiness to close single-shell tanks (SSTs) in the future. The HTI mission is to minimize technical uncertainties and programmatic risks buy conducting demonstrations to characterize and remove tank waste using technologies and methods that will be needed in the future to carry out tank waste remediation and tank farm closure.

The HTI team is comprised of representatives from the Project Hanford Management Contractors (PHMC), Pacific Northwest National Laboratory (PNNL), and private consultants. The team is working closely with the Washington State Department of Ecology (Ecology), various northwest stakeholders, and native American tribes to identify and develop waste retrieval performance criteria for subsequent formulation of acceptable closure criteria and standards for tank farms.

\subsection{PURPOSE AND SCOPE}

The purpose of this task is to develop the estimated costs associated with retrieval of the wastes from the four tanks in AX Tank Farm. The Waste Retrieval and Transfer Engineering Data Package for the Tank Waste Remediation System Environmental Impact Statement (Fredenburg 1995) served as a basis for retrieval data in the Tank Waste Remediation System (TWRS) Environmental Impact Statement (EIS). The sluicing cost data in that document were developed from Project W-320. To evaluate the impacts of retrieval alternatives associated with the Retrieval Performance Evaluation Criteria Alternatives (RPECA), additional costing information needs to be developed.

The engineering cost estimates developed for this report are based on previous cost data prepared for Project W-320 and the HTI 241-C-106 Heel Retrieval System. The costs presented in this report address only the retrieval of the wastes from the four AX farm tanks. This includes costs for equipment procurement, fabrication, installation, and operation to 
HNF-2693

Revision 1

retrieve the wastes. The costs to modify the existing plant equipment and systems to support the retrieval equipment are also included. The estimates do not include operational costs associated with pumping the waste out of the waste receiver tank (241-AY-102) between AX Farm retrieval campaigns or transportation, processing, and disposal of the retrieved waste.

The overall AX Farm waste flow path is shown in Figure 1. Only the costs associated with the items under the "Retrieve AX Farm Waste" block are included in this study.

Water spray/salt-well pumping is currently under consideration as the baseline retrieval process for sound (non-leaking) SSTs containing salt cake, however the current baseline retrieval process is Past-Practice Sluicing (PPS). Evaluation of Salt Well pumping was not included in this study because 1) it is inconsistent with current baseline retrieval process and 2) it would be unable to retrieve tanks $241-\mathrm{AX}-101$ and $241-\mathrm{AX}-103$ down to a residual waste volume of $10.2 \mathrm{~m}^{3}\left(360 \mathrm{ft}^{3)}\right.$ due to the insolubles in the tanks. If salt well pumping were to become the baseline retrieval process and resulted in lower costs for retrieving the salt cake in 241-AX-101 and 241-AX-103, the cost reduction would apply only to the $102 \mathrm{~m}^{3}\left(3,600 \mathrm{ft}^{3}\right)$ residual waste retrieval level, since salt well pumping technology is incapable of retrieving down to $10.2 \mathrm{~m}^{3}\left(360 \mathrm{ft}^{3}\right)$ of residual waste.

\subsection{SUMMARY}

Cost estimates are presented for three levels of waste retrieval. These retrieval levels are $102 \mathrm{~m}^{3}\left(3,600 \mathrm{ft}^{3}\right), 10.2 \mathrm{~m}^{3}\left(360 \mathrm{ft}^{3}\right)$, and $1.0 \mathrm{~m}^{3}\left(36 \mathrm{ft}^{3}\right)$ of residual waste in each tank. The cost estimates are rough order of magnitude (ROM) estimates prepared by HTI engineers for comparative purposes in the evaluation of RPECA and are not for budgetary use. The estimated expense and capital costs, including escalation and contingency, for the three levels of waste retrieval are summarized in Table 1. Details of the estimates are included in Appendices A through D.

The data are also broken down by Decontamination and Decommissioning (D\&D) costs, PHMC operating costs, PHMC operating worker-hours, and PHMC installation workerhours. The summary of this data breakdown is shown in Table 2. Details of these cost and worker-hour breakdowns are included in Appendix D. The costs include both contingency and escalation. The worker-hours include contingency only. 
HNF-2693

Revision 1

Figure 1. AX Tank Farm Waste Process Flowchart.
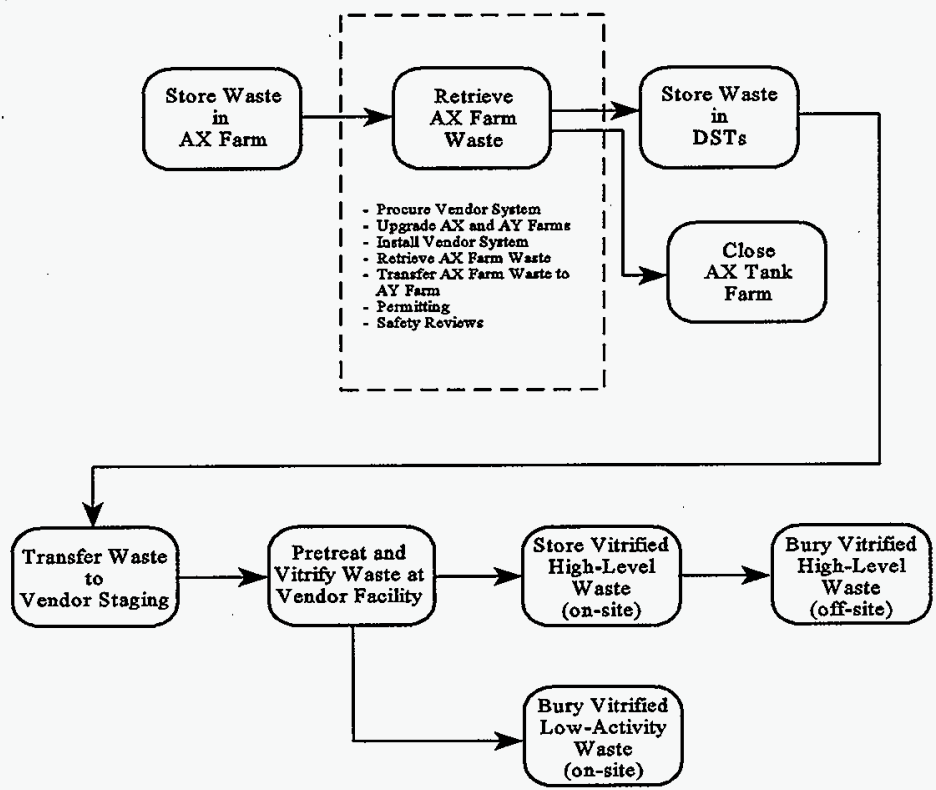
Table 1. Tank Waste Retrieval Cost Summary Estimate For AX Farm - K\$.

\begin{tabular}{|c|c|c|c|c|c|c|c|}
\hline & \multirow{2}{*}{ Task description } & \multicolumn{2}{|c|}{$3,600 \mathrm{ft}^{3(1)}$} & \multicolumn{2}{|c|}{$360 \mathrm{ft}^{3(1)}$} & \multicolumn{2}{|c|}{$36 \mathrm{ft}^{3(1)}$} \\
\hline & & $\operatorname{EXP}^{(2)}$ & $\mathrm{CAP}^{(3)}$ & $\operatorname{EXP}^{(2)}$ & $\mathrm{CAP}^{(3)}$ & $\operatorname{EXP}^{(2)}$ & $\mathrm{CAP}^{(3)}$ \\
\hline 1 & LLCE removal of tank equipment & 843 & 1,075 & 1,162 & 1,656 & 1,162 & 1,656 \\
\hline 2 & $\begin{array}{l}\text { Purchase/install sluicing systems and equipment for } \\
\text { tanks AX-101 and AX-103 }\end{array}$ & 18,446 & 4,000 & 18,446 & 4,000 & 18,446 & 4,000 \\
\hline 3 & Design/install control room for sluicers & 109 & 95 & 109 & 95 & 109 & 95 \\
\hline 4 & Purchase and install vehicle retrieval system in $\mathrm{AX}-104$ & 3,042 & 5,500 & 5,942 & 5,500 & 5,942 & 5,500 \\
\hline 5 & $\begin{array}{l}\text { Design/fabricate/install HVAC system for tanks AX- } \\
101,102,103 \text {, and } 104 \text {. }\end{array}$ & 282 & 700 & 382 & 700 & 382 & 700 \\
\hline 6 & Design/install $2000 \mathrm{ft}$ of 4 in. dia waste transfer lines. & 455 & 455 & 490 & 490 & 490 & 490 \\
\hline 7 & $\begin{array}{l}\text { Design/install new waste transfer jumper pit on west } \\
\text { side of AX farm }\end{array}$ & 284 & 50 & 284 & 50 & 284 & 50 \\
\hline 8 & Refurbish 11 pits in AX and AY farms & 11,500 & 2,000 & 14,500 & 2,000 & 14,500 & 2,000 \\
\hline 9 & PHMC BOP modifications/installations & 3,476 & 896 & $-4,223$ & 1,120 & 4,223 & 1,120 \\
\hline 10 & Safety \& Permitting & 1,393 & NA & 1,393 & NA & 1,393 & NA \\
\hline 11 & Sluicing Operational Costs & 2,409 & NA & 2,470 & NA & 2,470 & NA \\
\hline 12 & Vehicle Operational Costs & 592 & $\mathrm{NA}$ & 3,699 & NA & 10,871 & NA \\
\hline & SUB-TOTAL & 42,831 & 14,771 & 53,100 & 15,611 & 60,272 & 15,611 \\
\hline & TOTAL & & 502 & & & & 883 \\
\hline & TOTAL WITH CONTINGENCY \& ESCALATION & 11 & 964 & 137 & 136 & 15 & 450 \\
\hline
\end{tabular}

BOP = Balance of Plant

HVAC = Heating, ventilating, and air conditioning

LLCE $=$ Long-length contaminated equipment

PHMC $=$ Project Hanford Management Contractor

${ }^{1}$ Cubic feet of residual waste

${ }^{2}$ Expense Costs

${ }^{3}$ Capital Costs. 
Table 2. Estimated AY Farm Cost and Worker-Hour Breakdown (all 4 tanks).

\begin{tabular}{|l|c|c|c|}
\hline & $102 \mathrm{~m}^{3}\left(3,600 \mathrm{ft}^{3}\right)$ & $10.2 \mathrm{~m}^{3}\left(360 \mathrm{ft}^{3}\right)$ & $1.0 \mathrm{~m}^{3}\left(36 \mathrm{ft}^{3}\right)$ \\
\hline PHMC operating cost & $\$ 5,449,000$ & $\$ 12,729,000$ & $\$ 18,553,000$ \\
\hline PHMC operating worker-hours & 38,619 & 66,760 & 128,726 \\
\hline PHMC installation worker-hours & 241,970 & 325,528 & 325,528 \\
\hline D\&D & $\$ 1,008,000$ & $\$ 1,184,000$ & $\$ 1,184,000$ \\
\hline
\end{tabular}

$\mathrm{D} \& \mathrm{D}=$ Decontamination and decommissioning

PHMC $=$ Project Hanford Management Contractor.

A summary of the retrieval methods that are assumed to be used on each of the tanks for the three residual waste levels is shown in Table 3. Note that tanks 241-AX-102 and 241-AX-104 are assumed leakers and that the current waste inventory in 241-AX-104 is less than $102 \mathrm{~m}^{3}\left(3,600 \mathrm{ft}^{3}\right)$. The current waste volume inventories in the AX Farm tank are as follows:

$\begin{array}{ll}241-\mathrm{AX}-101 & 2,839,000 \mathrm{~L}(750,000 \mathrm{gal}) \\ 241-\mathrm{AX}-102 & 124,900 \mathrm{~L}(33,000 \mathrm{gal}) \\ 241-\mathrm{AX}-103 & 423,900 \mathrm{~L}(112,000 \mathrm{gal}) \\ 241-\mathrm{AX}-104 & 26,495 \mathrm{~L}(7,000 \mathrm{gal}) .\end{array}$

- Table 3. AX Farm Retrieval Methods.

\begin{tabular}{|l|c|c|c|c|}
\hline Residual waste & 241-AX-101 & $241-A X-102$ & $241-A X-103$ & $241-A X-04$ \\
\hline $102 \mathrm{~m}^{3} \cdot\left(3,600 \mathrm{ft}^{3}\right)$ & "PPS & Vehicle & ${ }^{*}$ PPS & NA \\
\hline $10.2 \mathrm{~m}^{3}\left(360 \mathrm{ft}^{3}\right)$ & ${ }^{*}$ PPS/Vehicle & Vehicle & ${ }^{*}$ PPS/Vehicle & Vehicle \\
\hline $1.0 \mathrm{~m}^{3}\left(36 \mathrm{ft}^{3}\right)$ & ${ }^{*}$ PPS/Vehicle & Vehicle & ${ }^{*}$ PPS/Vehicle & Vehicle \\
\hline
\end{tabular}

NA $=$ Not applicable

*Past-Practice Sluicing (PPS) includes two sluicers in each tank.

\subsection{RETRIEVAL SYSTEMS DESCRIPTIONS}

An updated PPS system is employed by project W320 as the method to remove the majority of the high-heat waste from tank 241-C-106. For AX Farm retrieval, the W-320 sluicing process is modified by using two sluicers in tanks $241-\mathrm{AX}-101$ and $241-\mathrm{AX}-103$. 
This is made necessary by the air lift circulators (ALCs) that obstruct portions of the tanks from the sluicing jets and to improve the sluicing efficiency. Double-shell tank (DST) 241-AY-102 is the receiver tank for the waste retrieved from AX Farm. Only one of the sluicers will be in operation at any given time. Tank 241-AY-102 will be charged with about $1,514,000 \mathrm{~L}(400,000 \mathrm{gal})$ of water that will be recirculated to AX Farm at a rate of $1,135 \mathrm{~L} / \mathrm{min}(300 \mathrm{gal} / \mathrm{min})$ through new waste transfer lines.

The vehicle retrieval system is a "second generation" version of the 241-C-106 Heel Retrieval System. This system consists of a retrieval vehicle that is lowered into the tank through a riser and retrieves the waste with a sluicing head employing high pressure water jets to break up the waste. The system includes tools that can clean the sides of the tank, clean the internal and external ALC surfaces, and cut-off the thermocouple wells that protrude below the ALCs.

\subsection{RISKS AND UNCERTAINTIES}

There are considerable risks and uncertainties associated with assuming that the vehiclebased retrieval system is capable of retrieving waste to the required degree. It is unlikely that a volume of $1.0 \mathrm{~m}^{3}\left(36 \mathrm{ft}^{3}\right)$ of residual waste can be achieved with current technologies. The 1996 National Research Council report Barriers To Science, Technical Management of the Department of Energy Environmental Remediation Program (NRC 1996) contains the following statement regarding retrieval of Hanford tank wastes: "The committee has seen no analysis demonstrating that essentially complete waste removal is technically achievable or even advisable for all of many of the tanks." The statement remains as true today as it was two years ago. Operation of the Project W-320 sluicing system in tank 241-C-106 (scheduled to start in August 1998) and operation of the HTI 241-C-106 Heel Retrieval System vehicle (scheduled to start in October 1999) will provide factual data on the capabilities of these systems to retrieve waste from the Hanford SSTs. The data in this study should be reviewed and updated at the conclusion of those projects. Several of the more important risks/uncertainties related to this study are listed below:

1. Technical Capability. There are considerable risks in assuming that any currently available technology can retrieve waste to a level approaching $1.0 \mathrm{~m}^{3}$ $\left(36 \mathrm{ft}^{3}\right)$. The effectiveness of the vehicle-based retrieval system has not yet been demonstrated in a Hanford waste tank and remains unknown. Further, there is considerable uncertainty that removal to these levels can be verified.

2. Tank Obstructions. There are also considerable uncertainties associated with the ability of the vehicle-based system to retrieve waste among the 22 ALCs that are in the AX Farm tanks. There is space for the vehicle to operate below the ALCs (after the thermocouple wells have been cut), but the umbilical management problems will be challenging. 
HNF-2693

Revision 1

3. Air Lift Circulators. The question of the ability of the vehicle to remove the waste from the interior of the 76-cm (30-in.) diameter ALCs (pipe) also remains unanswered and un-demonstrated. To achieve the $1.0 \mathrm{~m}^{3}\left(36 \mathrm{ft}^{3}\right)$ residual waste volume, essentially all of the waste will have to be removed from the interior and exterior surfaces of the ALCs.

4. Water Limitations. An additional risk associated with the estimates presented in this report is the uncertainty in assuming that the vehicle based retrieval system will be capable of reducing the waste inventory to $1.0 \mathrm{~m}^{3}\left(36 \mathrm{ft}^{3}\right)$ without using excess amounts of water in the retrieval process. Water addition limitations could be a barrier to achieving a final clean-out to $1.0 \mathrm{~m}^{3}\left(36 \mathrm{ft}^{3}\right)$ of waste.

5. Operational Time. Another uncertainty involves the assumed operating times required for the vehicle based system to clean out the tanks to the various residual waste levels. The assumed times (and associated retrieval rates) are based on engineering judgement, discussions with personnel familiar with the 241-C-106 heel retrieval task, and experience at the Gunite and Associated Tanks (GAAT) at Oak Ridge National Laboratory. Increased retrieval times would drive up the costs and the potential increase in cost could be dramatic for the $1.0 \mathrm{~m}^{3}\left(36 \mathrm{ft}^{3}\right)$ case.

6. Salt Cake Sluicing. Past sluicing experience at Hanford has been with sludge types of waste. The assumption that PPS will retrieve the large majority of the salt cake from tanks 241-AX-101 and 241-AX-103 is not backed up with actual experience. This lack of experience along with the limited knowledge of the present salt cake properties results in significant uncertainties in the ability of the sluicing system to perform satisfactorily.

\subsection{ASSUMPTIONS}

The assumptions listed below were adopted as the planning basis for the cost estimates developed in this report.

1. PPS will not be an acceptable retrieval process for tanks 241-AX-102 and 241-AX-104 because 1) they are classified as leakers and 2) the small volumes of waste in these tanks can be more cost effectively retrieved by a vehicle system.

2. PPS will be the process used to retrieve the waste from tanks $241-\mathrm{AX}-101$ and 241-AX-103 to $102 \mathrm{~m}^{3}\left(3,600 \mathrm{ft}^{3}\right)$ of residual waste. 
HNF-2693

Revision 1

3. The "next generation" vehicle-based HTI 241-C-106 Heel Retrieval System will be used to retrieve the wastes from tanks 241-AX-102 and 241-AX-104.

4. PPS will not be capable of retrieving tanks $241-\mathrm{AX}-101$ and $241-\mathrm{AX}-103$ to $10.2 \mathrm{~m}^{3}\left(360 \mathrm{ft}^{3}\right)$ or less of residual waste. There are $22 \mathrm{ALCs}$ in each of the AX Farm tanks. These are 76-cm (30-in.) diameter pipes that "shadiow" a significant portion of the tank volume from the sluicing jet and limit the amount of waste that can be retrieved without removal of the ALCs.

5. Retrieval to the $1.0 \mathrm{~m}^{3}\left(36 \mathrm{ft}^{3}\right)$ residual waste level will employ the same techniques as for the $10.2 \mathrm{~m}^{3}\left(360 \mathrm{ft}^{3}\right)$ level. The difference is the additional operating time required to accomplish the desired residual waste level.

6. Tank 241-AY-102 will be the receiver tank for all of the retrieved waste.

7. The W-320 slurry distributer in tank 241-AY-102 will be reused for AX Farm retrieval.

8. The W-320 Slurry pump in tank 241-AY-102 will be replaced with a new pump appropriately sized for retrieval of AX Farm (radiation damage will render the W-320 pump unusable).

9. A new above ground waste transfer pit will be required for flow diversion (using jumpers) from the AX Farm tanks.

10. Retrieval of tank 241-C-106 hard heel, by HTI, will successfully demonstrate the capability of the retrieval system to reach the $10.2 \mathrm{~m}^{3}\left(360 \mathrm{ft}^{3}\right)$ residual waste volume.

11. Waste transportation, processing, and disposal costs are part(s) of other work packages.

\subsection{WASTE MEASUREMENT TECHNIQUES}

There are two developed, practical technologies for obtaining volume measurements of the waste (see Appendix $E$ telecon memo). These technologies include the use of surface measurement tools and subsequent calculation of the waste volume. The surface measurement methods are photogrammetry and video cameras. These provide topographical maps of the waste surface that results in conservative estimates the actual waste volume. Surface roughness of the waste, actual location of the tank walls and floor (relative to the waste surface), and waste adhering to the surfaces of the ALC all contribute to the inaccuracies of 
HNF-2693

Revision 1

the measurements. The best accuracy that can be expected from using these systems in the AX farm tanks is about $10.2 \mathrm{~m}^{3} \pm 5.1 \mathrm{~m}^{3}\left(360 \mathrm{ft}^{3} \pm 180 \mathrm{ft}^{3}\right)$.

In summary, there is no practical system that can measure residual waste volumes down to $1.0 \mathrm{~m}^{3}\left(36 \mathrm{ft}^{3}\right)$. To illustrate the problem, a thin film of waste $0.013 \mathrm{~cm}(0.005 \mathrm{in}$.) thick evenly distributed over the interior surfaces of the tank walls and floor, and the ALCs results in $1.0 \mathrm{~m}^{3}\left(36 \mathrm{ft}^{3}\right)$ of residual waste.

A third system (Structured Light System) has the potential to measure residual waste volumes down to $5.1 \mathrm{~m}^{3} \pm 2.6 \mathrm{~m}^{3}\left(180 \mathrm{ft}^{3} \pm 90 \mathrm{ft}^{3}\right)$, but requires development and repackaging for use in a $\mathrm{AX}$ farm tank. The Structured Light System could be used in conjunction with vehicle on-board sensors to improve the overall accuracy, but it would not approach $1.0 \mathrm{~m}^{3}\left(36 \mathrm{ft}^{3}\right)$. Typical vehicle on-board sensors include video cameras, magnetometers, and waste depth gages. Development of a structured light system is not currently funded.

\subsection{REFERENCES}

Fredenburg, E. A., 1995, Waste Retrieval and Transfer Engineering Data Package for the

Tank Waste Remediation System Environmental Impact Statement, WHC-SD-WM-EV-097, Rev. 0, Westinghouse Hanford Company, Richland, Washington.

Manderbach, M. W., 1997a, Cost Normalization Unit Estimates, LMHC96WO-0006, CO-98-TWRS-098, letter to T. H. May (December 31), Fluor Daniel Northwest Inc., Richland, Washington.

Manderbach, M. W., 1997b, W320 Scrub Study Estimate, TR-HTI-002, Fluor Daniel Northwest, Richland, Washington.

May, T. H., 1997, Hanford Tanks Initiative Retrieval Demonstration Project Design Concept, HNF-SD-HTI-ES-001, Rev. 0, Numatec Hanford Corporation, Richland, Washington.

NRC, 1996, Barriers To Science, Technical Management of the Department of Energy Environmental Remediation Program, National Research Council, Washington, D.C.

Becker, D. L., 1997, AX Farms Waste Inventory Study for Hanford Tanks Initiative, HNF-SD-HTI-TI-001, Numatec Hanford Corporation, Richland, Washington. 


\section{HNF-2693}

Revision 1

This page intentionally left blank. 
HNF-2693

Revision 1

\section{APPENDIX A}

\section{COST ESTIMATE DETAILS FOR $102 \mathrm{~m}^{3}\left(3,600 \mathrm{ft}^{3}\right)$ RESIDUAL WASTE LEVEL}


HNF-2693

Revision 1

This page intentionally left blank.

A-2 
HNF-2693

Revision 1

APPENDIX A

\section{$102 \mathrm{~m}^{3}\left(3,600 \mathrm{ft}^{3}\right)$ COST DETAILS}

Retrieval to $102 \mathrm{~m}^{3}\left(3,600 \mathrm{ft}^{3}\right)$ Residual Waste--Cost Summary. (2 Sheets)

\begin{tabular}{|l|l|r|}
\hline & \multicolumn{1}{|c|}{ Task description } & \multicolumn{1}{|c|}{ Cost } \\
\hline 1 & LLCE removal of tank equipment & $1,918,000$ \\
\hline 2 & $\begin{array}{l}\text { Procurement and installation of sluicing systems and equipment } \\
\text { for tanks 241-AX-101 and 241-AX-103 }\end{array}$ & $22,446,000$ \\
\hline 3 & Design/fabricate/install control room (trailer) for sluicers & 204,000 \\
\hline 4 & Purchase and install vehicle retrieval system in 241-AX-104 & $8,542,000$ \\
\hline 5 & $\begin{array}{l}\text { Design/fabricate/install HVAC system for tanks 241-AX-101, } \\
102, \text { and 103 }\end{array}$ & 982,000 \\
\hline 6 & $\begin{array}{l}\text { Design/install approximately 610 m (2,000 ft) of 10-cm (4-in.) } \\
\text { diameter waste transfer lines between 241-AY-102 and } \\
241-A X-101,102, \text { and 103 }\end{array}$ & 910,000 \\
\hline 7 & $\begin{array}{l}\text { Design/install new waste transfer jumper pit on west side of AX } \\
\text { farm (Manderbach 1997a) }\end{array}$ & 334,000 \\
\hline 8 & $\begin{array}{l}\text { Decontaminate and clean out 9 pits in AX and AY farms based on } \\
\text { W-320 experience. }\end{array}$ & $13,500,000$ \\
\hline 9 & PHMC BOP modifications/installations & $4,372,000$ \\
\hline 10 & Safety and Permitting & $1,393,000$ \\
\hline 11 & Sluicing Operational Costs & $2,409,000$ \\
\hline 12 & Vehicle Operational Costs & $59,602,000$ \\
\hline & & \multicolumn{1}{c}{ TOTAL } \\
\hline
\end{tabular}

BOP $=$ Balance of Plant

CCTV = Closed-circuit television

HVAC $=$ Heating, ventilating, and air conditioning

LLCE $=$ Long-length contaminated equipment

PHMC $=$ Project Hanford Management Contractor. 
Contingency and escalation are assumed to be the same as used by Fluor Daniel Northwest (FDNW) in the preparation of the Project Design Concepts (May 1997). These are as follows:

Escalation is 5.3 percent for FY 1999 through FY 2006 ( 8 years) for a total escalation of 51.2 percent.

32 percent contingency

TOTAL RETRIEVAL COST $\$ 57,602,000 \times 1.512 \times 1.32=\$ 114,964,000$

$\mathrm{DB} \backslash 3600-\mathrm{TBL}$ 
HNF-2693

Revision 1

\section{1. $\quad 102 \mathrm{~m}^{3}\left(3,600 \mathrm{ft}^{3}\right)$ Long-Length Contaminated Equipment Removal}

There are 6 pieces of Long-Length Contaminated Equipment (LLCE) that will be removed from the tank pits in AX farm. These will be removed with the existing LLCE system and packaged for burial or disposal as required.

The estimated cost for the setup of the LLCE, removal of the item from the waste tank, packaging, and burial/storage is $\$ 418,000$ for the initial item based on the slurry pump and sluicer removal estimates contained in Manderbach (1997a). Costs for subsequent items are $\$ 300,000$ each accounting for lessons learned on the initial removal.

\begin{tabular}{|l|r|}
\hline Tank 241-AY-102 slurry pump removal & $\$ 418,000$ \\
\hline Tank 241-AX-101 pit 01A steam coil & $\$ 300,000$ \\
\hline Tank 241-AX-101 pit 01B Sluicer & $\$ 300,000$ \\
\hline Tank 241-AX-102 pit 02A Sluicer & $\$ 300,000$ \\
\hline Tank 241-AX-102 pit 02B Pump & $\$ 300,000$ \\
\hline Tank 241-AX-103 pit 03A Sluicer & $\$ 300,000$ \\
\hline TOTAL (for $102 \mathrm{~m}^{3}\left[3,600 \mathrm{ft}^{3}\right]$ case) & $\$ 1,918,000$ \\
\hline
\end{tabular}

DB\3600LLCE 


\section{Revision 1}

\section{2. $102 \mathrm{~m}^{3}\left(3,600 \mathrm{ft}^{3}\right)$ Sluicing Equipment Fabricate/Installation Costs}

The cost estimate for the design/fabrication and installation of sluicing systems on tanks 241-AX-101 and 241-AX-102 is based on the enhanced sluicing cost estimate for 241-C-106 prepared by FDNW for Job no. E20144 (file no. Z437SAE2) (summary sheet attached). The estimate was modified as detailed below to more accurately reflect the AX farm conditions.

The total projected cost estimate without escalation or contingency is $\$ 34,140,000$ including site allocations. The following items were removed from the estimate as redundant or not applicable:

\begin{tabular}{|l|r|}
\hline Regulatory compliance & $1,281,000$ \\
\hline Accident analysis & 650,000 \\
\hline Pump pit 241-C-06A & $2,303,000$ \\
\hline Heel pit 241-C-06B & $1,967,000$ \\
\hline Sluice pit 241-C-06C & $1,922,000$ \\
\hline Enc'd pipe pump to heel pit & 298,000 \\
\hline Enc'd pipe heel to sluice pit & 223,000 \\
\hline Heel jet removal & 618,000 \\
\hline Sluicer removal & 594,000 \\
\hline Vendor perform retrieval & $2,000,000$ \\
\hline Vendor Demobilization & 500,000 \\
\hline Ready tank for closure & $2,500,000$ \\
\hline SUB-TOTAL & $14,856,000$ \\
\hline
\end{tabular}

The following items were added to the estimate to account for operation in two tanks:

\begin{tabular}{|l|r|}
\hline Vendor equipment & $2,000,000$ \\
\hline Vendor equipment installation & $1,162,000$ \\
\hline SUB-TOTAL & $3,162,000$ \\
\hline
\end{tabular}

TOTAL $(34,140,000+3,162,000-14,856,000)=\$ 22,446,000$ 
FLUOR DAKIEL nORTHHEST, IHC. NUHATEC JANFORD CORPORATION

Jo3 XO. 520144

FILE HO. Z137SAEZ
* inst . rRteractive estrmattho *

concert - ENHANCED StUICINC

$$
\text { ORDER OF MAGHITUDE }
$$

PIMCROL - PROJECT COST SUMMARY

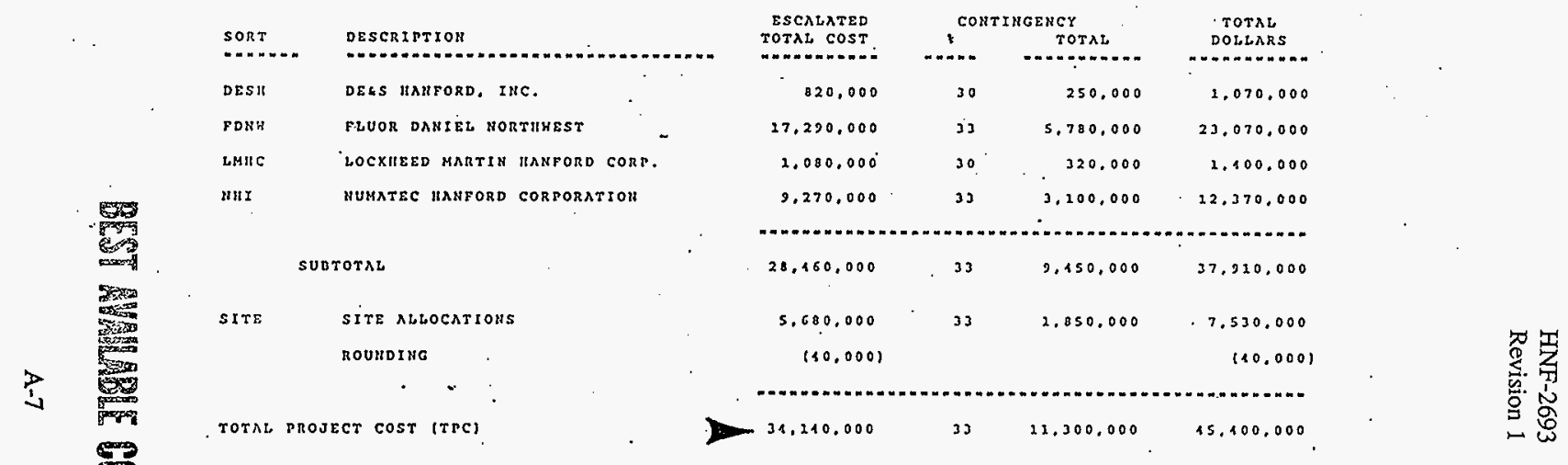

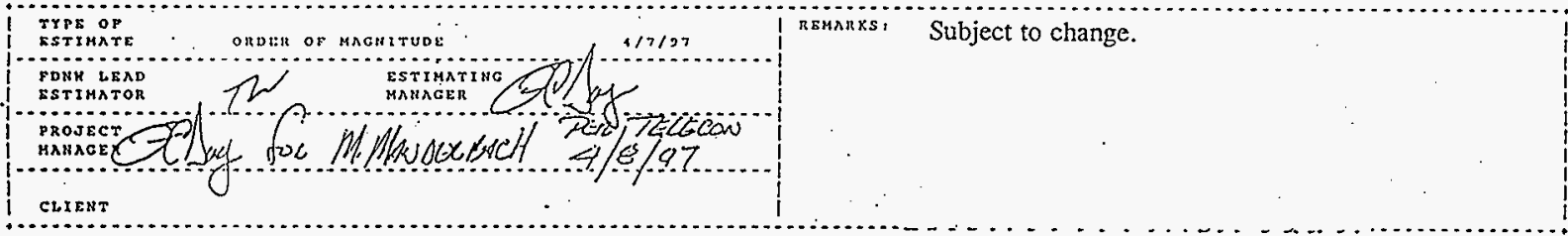

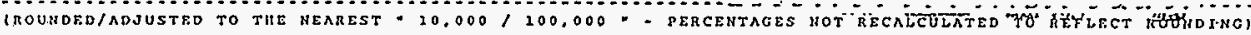


HNF-2693

Revision 1

\section{3. $\quad 102 \mathrm{~m}^{3}\left(3,600 \mathrm{ft}^{3}\right)$ Sluicer Control Room}

The estimated cost for the control room/lunch room is taken from the $1994 \mathrm{~W}-320$ estimate (Job no. W-320/ER4319 page 23 attached). One control room for the sluicer systems used in tanks $241-\mathrm{AX}-101$ and $241-\mathrm{AX}-103$ is adequate. This control room would be located outside the tank farm boundaries.

The W-320 control room was not installed (a mobile office was modified) so the costs for the control room are not included in the later estimates.

From page 23 of the estimate (rounded) $\$ 204,000$

$\mathrm{DB} \backslash 3600 . \mathrm{CNT}$ 
XAISER EULIUEERS HAUFORD

HEST THGHOUSE HAHFORD COHPAHY

JOI KO. $H=320 / E R 4319$

FILE HO W

$\cos t$

CODE/UBS DESCRTPTIOY

3490. AY EQUTPHEIT

3510 HYORAULIC TRAILER/STRONGBACX

3560 CEHRTIC FAERICATIOH

4212 CIIRL RH IHSTR. IHSTALLATIOH.

4221 TRAHSEER LIHE

4223 CONTROL RH/LUNCH RH

4313 CORE DRILLS

4315

4322

4324

4341

4343

4351

4352

P. 4353

4354

4356

x 4357

4412

red 4413

4414
4416

4416

422

4423

$\cos 4430$

4509
4510

44543

4804

04805

2606

24610

4777

PIt SLEEVE/EHOEOS

PIY SLEEV

EHCASED PIPING IHSTALLATIOU

C- FARH IUSTRUKEUT AIR \& VEUT

C-FARH ELECTRICAL

MASF HOCX-UP

SLUICIIIG EQUIP.

CHILLER SXIO

EXIIAUST SYSTEH

FOC SUPRESSIOII SYS

DIRECTED MIR SYSTEM

EXISTIUG AIR IULET HOD'S

HISC PADS

HISC. IHSTRUMEUTATIOU

PIJ SLEEVE/ EHBEDS

JUAPERS

PIT DACKFILL

EXCAVATIOUI PIPIUG

EACASEO PIPIHG IIISIALLATIOH.

IIYAC SXIO PROCUREHEUT

SLUICIHG EOUIP.PROCUREMEIH

SLUICING EQUIPHENT C-106

COLD TESTIIIG

FABRICATIOLIIHSTALLATIOU

GEHERAL COHSTRUCTION SUPPOR

COHTAIIER TRAILER EAB CTC

GEHEAAL COHSTRUGTIOU SUPPORT-SLUICE

GEMERAL. \& TECH. SERVICES-SLUICIIIG

TOTAL 700 SPECIAL EOUIP/PROCESS SYSIEH
**. 1EST : IITERACTIVE ESTIHATIHO *

TAHK $241-C-106$ SIUICIHG REVISIOH HI DOE $40 \%$ PRELIMIIIARY ESTIMATE

- COSI COOE ACCOUNT SUHHARY

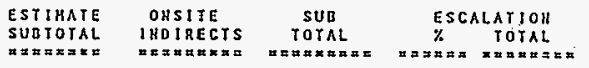

PAGE 23 OF 32

DATE $10 / 21 / 94$ O7:56:21

DY GDC/JPH/DKH/CDL/KDE

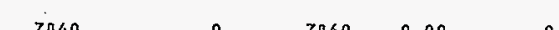

7060
493220
660184
713564

713564

6403

204417

499006

372617

254681

254431

3074

369740

512504

40410

237120

4549
54897

13306

7917

218925

134525

240235

711

0.459

40398

2339
66057

57099

1017615

2501207

1505123

3307096
936509

49598

49598
304220

509500

19703677

\begin{tabular}{|c|c|}
\hline 0 & 7060 \\
\hline 0 & 493220 \\
\hline 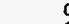 & 680184 \\
\hline 0 & 713564 \\
\hline 271346 & 1530893 \\
\hline & $\begin{array}{r}7709 \\
248118\end{array}$ \\
\hline 41701 & $\begin{array}{r}246118 \\
499806\end{array}$ \\
\hline 0 & 102622 \\
\hline 0 & 372617 \\
\hline 0 & 254481 \\
\hline 0 & 39131 \\
\hline 0 & 069740 \\
\hline o & 247311 \\
\hline 0 & 512504 \\
\hline o & 40418 \\
\hline 0 & 237120 \\
\hline C & 4549 \\
\hline 0 & 54,897 \\
\hline 0 & 13308 \\
\hline 0 & 7917 \\
\hline 0 & 210925 \\
\hline 0 & 134525 \\
\hline 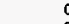 & 35161 \\
\hline 0 & 240235 \\
\hline 0 & 711 \\
\hline o & 0659 \\
\hline 0 & 48398 \\
\hline . & 2339 \\
\hline 0 & 366957 \\
\hline 0 & 057899 \\
\hline 0 & 1017615 \\
\hline 0 & 2501207 \\
\hline 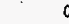 & 1505123 \\
\hline 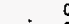 & 3307896 \\
\hline & 936509 \\
\hline 0 & 49580 \\
\hline & 304220 \\
\hline & \\
\hline
\end{tabular}

314053

20098530

a$$
0.00
$$

0.00
0.00

$1.60 \quad 11417^{\circ}$

$1.60 \quad 24495$

1.61

1.60

$3.61 \quad 13451$

$3.61 \quad 9107$

$3.61, \quad 31397$

$3.61 \quad 1459$

$3.61 \quad 8560$

3.61

3.61

3.61

3.81

3.09

3.89

3.09

3.09

3.09

3.09

3.09

2.46

2.46

2.46
0.12

0.14

2.17

2.17

2.17

$1.77 \quad 356343$

164
1981

431

288

BS 16

1360

1360
9657

20
329

1083

14274

21104

25033

63498

1749

4597.
20322

0330
0

Cont I HGENCY

TOTAL

DOLLARS

7060
493220

660134

724901

1555387

7033

250056

106326

106326

30060

203668

001137

$25623 \%$

531005

41877

4,713

56878

13789

2745

139758

36528

257892

0700

50281

02430

379003

2644705

1506072

3312493

056831

49593
392550

602363

$20 \quad 1572$

$1572 \quad 9432$

$14190 \quad$
109658

$101246 \quad 906227$

$330369 \quad 1043757$

50011

144076

31890

115821
79100

79100
12163.

180227

51240

159302

12563

53764

14 i4

14221

3447

56924

41927

10959

77360

222

i5084

728

76247

175801

158300

156390

396706

375368

378368

191366
4960

70512

120477

3757

300067

661025

136225

501889

342769

1081365

307407

690307 四

28440

$\begin{array}{r}6127 \\ \hline\end{array}$

71090

17235

10254

204364

181685

47400

335259

960

11425
65365

3158

1054803

1180046

3041410

1662430

100804

360197

471069

722858

20454072

357657 .

24031443
$3.61 \quad 1412$

$3.69 \quad 13501$

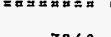


HNF-2693

Revision 1

\section{4. $\quad 102 \mathrm{~m}^{3}\left(3,600 \mathrm{ft}^{3}\right)$ Vehicle Retrieval System Costs}

\section{Vendor Costs}

The vendor cost estimate is based on the two vendor systems currently being designed for the retrieval of the heel in tank 241-C-106. This also assumes that the same type of service contract will be used to procure the retrieval systems for the $\mathrm{AX}$ farm as is being used for the procurement of the 241-C-106 vehicle retrieval system.

\section{Vendor supplied system/equipment}

Design, fabrication, testing, and delivery of a vehicle based retrieval system ready to install in the AX farm (based on discussions with HTI 241-C-106 Heel Retrieval System Engineers).

$\$ 5,500,000$

\section{Pre-operational work at $\mathbf{A X}$ farm}

Operational Readiness Review (ORR), training, and acceptance testing based on 6-month duration. Three person vendor crew, four shifts, and four person home office support on one shift.

$$
\text { Labor (16 persons @ \$75/hr for } 24 \text { weeks) } \quad \$ 1,152,000
$$$$
\text { Per diem (16 persons @ \$80/day for } 24 \text { weeks) } \quad \$ 30,700
$$

Warehouse and office rental in the Tri-Cities area.

Twelve month duration based on the use of one vehicle in 241-AX-102.

$\$ 60,000$

Sub-total

$\$ 6,700,000$

PHMC Bid and Award

Based on HTI 241-C-106 Heel Retrieval System costs

$\$ 200,000$

PHMC Contract Management

Based on HTI 241-C-106 Heel Retrieval System costs

$\$ 400,000$

\section{PHMĈ ORR/ATP}


HNF-2693

Revision 1

Installation Costs $\quad$ Sub-total $\$ 1,000,000$

The estimated cost to install a vehicle based retrieval system in 241-AX-104 is assumed to be the same as for Tank 241-C-106. The installation costs in 241-C-106 is from sheet 17 (attached) of the HTI baseline estimate. This does not include the costs to modify the farm/tank for acceptance of the vehicle system.

Sub-Total

$\$ 842,500$

TOTAL

$\$ 8,542,000$

$\mathrm{DB} \backslash 3600$.VEH 


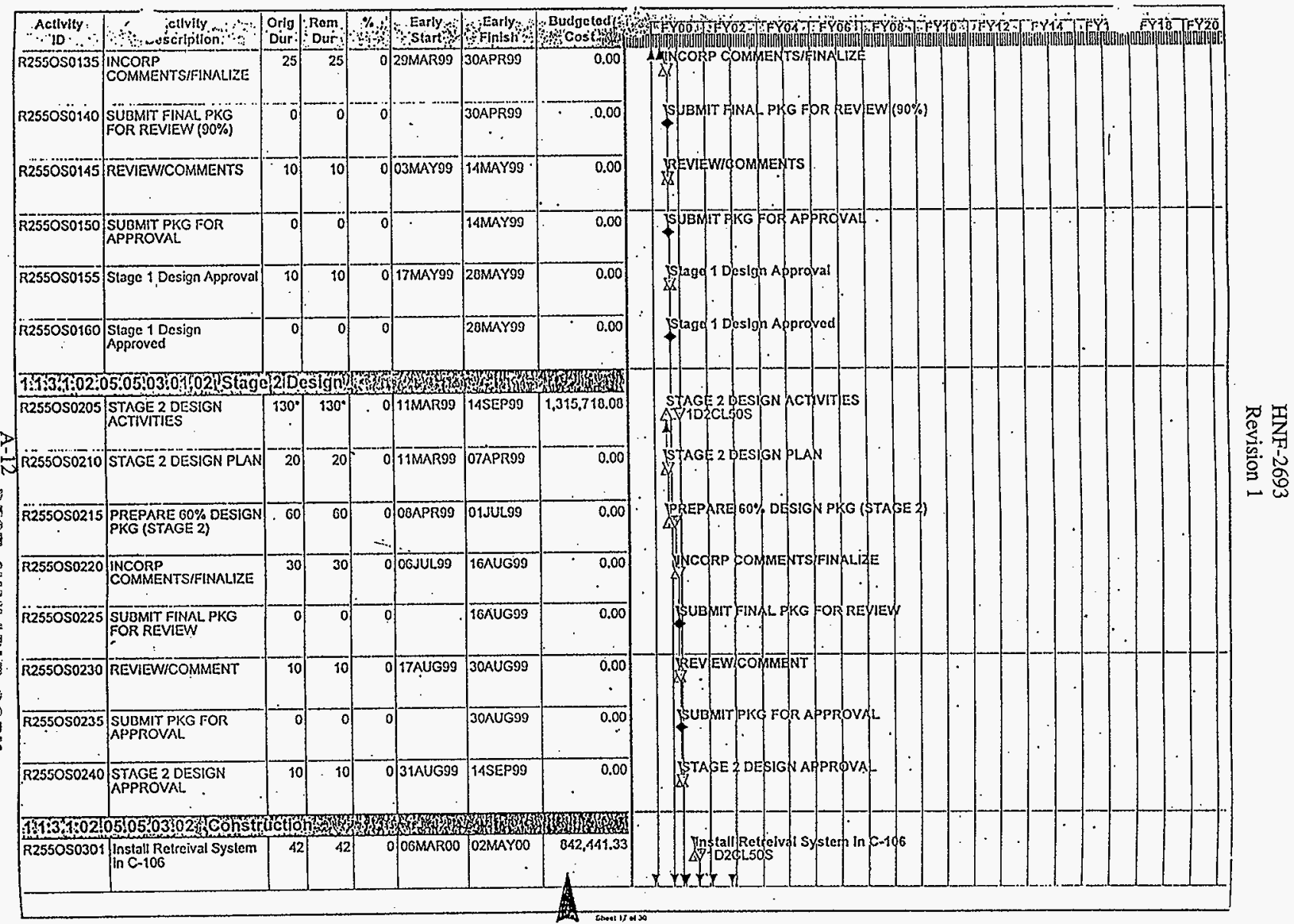


HNF-2693

Revision 1

\section{5. $102 \mathrm{~m}^{3}\left(3,600 \mathrm{ft}^{3}\right)$ HVAC System Design/Installation Costs}

The estimate for a new AX farm HVAC system is based on the FDNW W-320 HVAC skid estimate contained in file no. W320PDA4, job no. W-320/P7448M (page 14 attached). Assume the AX farm HVAC is of the same magnitude and will cost the same. The increased cost of connecting to the 3 tanks in $\mathrm{AX}$ farm is offset by the reduced design costs associated with using the existing W-320 design.

AX Farm HVAC System $\quad 1$ ea

TOTAL $\$ 982,000$

DB $\backslash 3600 H V A C$ 


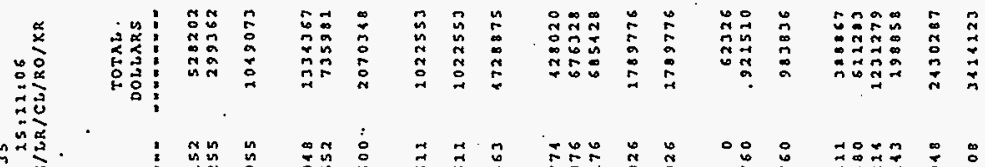

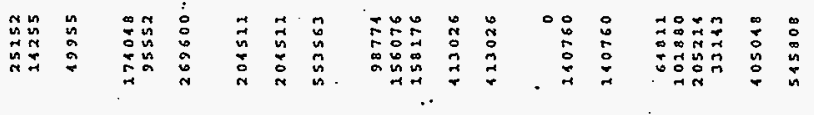

a. $2 \geq$

.

$\overbrace{0=1}$

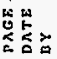

ह

nn.

$\stackrel{2}{2}=$

n $n$

읐옹 응 응

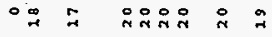

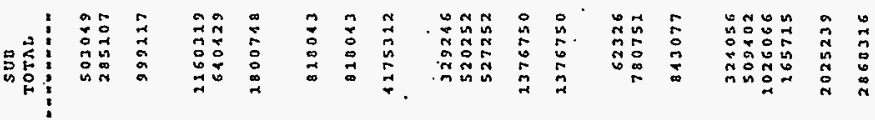

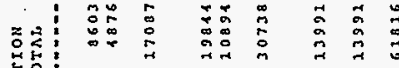

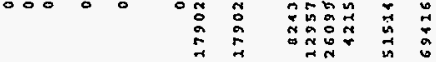

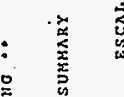

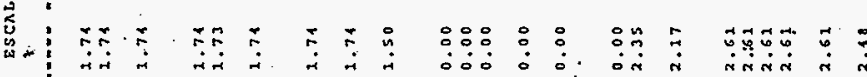

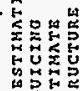

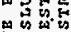

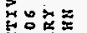

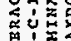

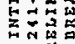

1

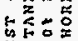

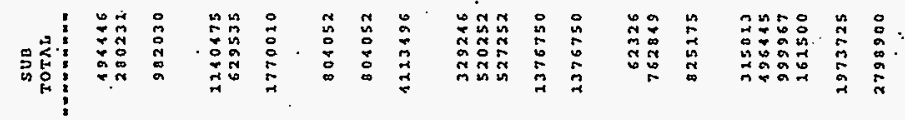

\%

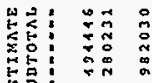

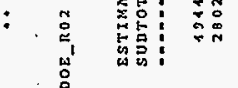

悹

㝵:

政

s

웅

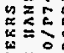

눙

ज़

然.

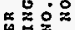

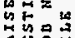

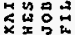

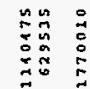

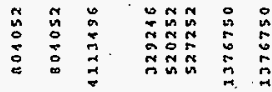

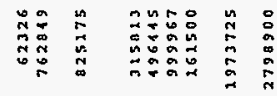
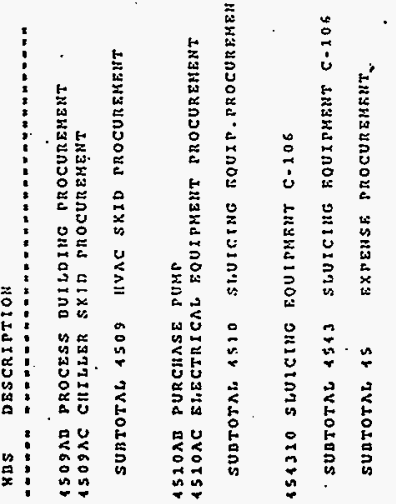

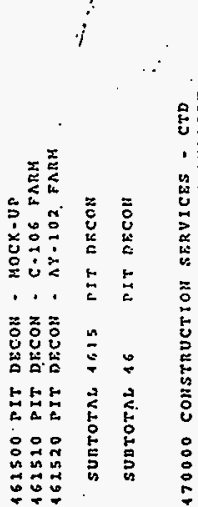

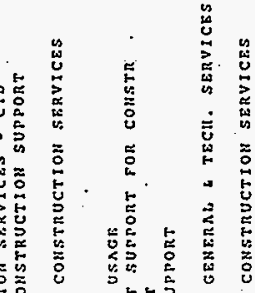

A-14 
HNF-2693

Revision 1

6. $\quad 102 \mathrm{~m}^{3}\left(3,600 \mathrm{ft}^{3}\right)$ Waste Transfer Line

\begin{tabular}{|c|c|}
\hline Description & Length \\
\hline \multicolumn{2}{|l|}{ 241-AY-102 } \\
\hline Pit $02 \mathrm{~A}$ to new valve pit & $76 \mathrm{~m}(250 \mathrm{ft})$ \\
\hline Pit $02 \mathrm{E}$ to new valve pit & $72 \mathrm{~m}(235 \mathrm{ft})$ \\
\hline \multicolumn{2}{|l|}{ 241-AX-101 } \\
\hline Pit 01A to new valve pit & $67 \mathrm{~m}(220 \mathrm{ft})$ \\
\hline Pit $01 \mathrm{~B}$ to new valve pit & $61 \mathrm{~m}(200 \mathrm{ft})$ \\
\hline Pit 01D to new valve pit & $56 \mathrm{~m}(185 \mathrm{ft})$ \\
\hline \multicolumn{2}{|l|}{ 241-AX-102 } \\
\hline Pit $02 \mathrm{~A}$ to new valve pit & $58 \mathrm{~m}(190 \mathrm{ft})$ \\
\hline Pit $02 B$ to new valve pit & $50 \mathrm{~m}(165 \mathrm{ft})$ \\
\hline \multicolumn{2}{|l|}{ 241-AX-103 } \\
\hline Pit $03 \mathrm{~A}$ to new valve pit & $38 \mathrm{~m}(125 \mathrm{ft})$ \\
\hline Pit $03 C$ to new valve pit & $41 \mathrm{~m}(135 \mathrm{ft})$ \\
\hline Pit $03 \mathrm{D}$ to new valve pit & $29 \mathrm{~m}(95 \mathrm{ft})$ \\
\hline \multicolumn{2}{|l|}{ 241-AX-104 } \\
\hline None Required for 3,600 case & -- \\
\hline Total line length & $555 \mathrm{~m}(1,820 \mathrm{ft})$ \\
\hline Cost & $\$ 910,000$ \\
\hline
\end{tabular}

Note 1: Fabrication and installation cost for the waste transfer line is $\$ 3,279 / \mathrm{m}(\$ 1,000 / \mathrm{ft})$ for a double line based on W-320 experience.

Note 2: Each pit above requires core drill and nozzle installation, i.e., 10 each for the $102 \mathrm{~m}^{3}\left(3,600 \mathrm{ft}^{3}\right)$ case. 
HNF-2693

Revision 1

\section{7. $102 \mathrm{~m}^{3}\left(3,600 \mathrm{ft}^{3}\right)$ Pit Design/Installation Costs}

The estimate for a new AX farm above grade transfer line (jumper) pit is based on the pit cover block fabrication and caisson/slab support for the manipulator arm costs contained in the Cost Normalization Unit Estimates (Manderbach 1997a). Assume same cover block costs and that the pit will cost the same as the manipulator slab.

\begin{tabular}{|l|r|}
\hline Cover block & $\$ 102,000$ \\
\hline Pit & $\$ 232,000$ \\
\hline TOTAL & $\$ 334,000$ \\
\hline
\end{tabular}

DB\3600.PIT 
HNF-2693

Revision 1

\section{8. $\quad 102 \mathrm{~m}^{3}\left(3,600 \mathrm{ft}^{3}\right)$ Pit Decontamination Costs}

For the $102 \mathrm{~m}^{3}\left(3,600 \mathrm{ft}^{3}\right)$ case, 8 pits in $\mathrm{AX}$ farm and the pump pit at 241-AY-102 are used for the retrieval activities.

Discussed the condition and radiation levels in the pits with Dave Bragg in a Telecon $4 / 20 / 98$ as summarized below.

Dave is not aware on any record of the activities that have been carried out in the last 15 years in the pits. Dave indicated that the pits probably haven't been opened in the last 15-20 years. Dave has no information on the pits as compared to the 241-C-106 pits that were decontaminated for Project W-320. Dave stated that John W. Bailey might have some recollection of the $\mathrm{AX}$ farm retrieval sluicing activities and that he would be a good source to try. John Bailey indicated that the pits in AX farm should be in better condition than those in C Farm (the drains should work).

For the purposed of preparing this estimate, will assume that the pits are in comparable condition to the 241-C-106 pits. From the FDNW estimate for the Vehicle Based Retrieval System, Job no. E20144 (file ZA37SAF2), the allocated cost for decontamination of the pits is $\$ 1,500,000$ each (page 7, item 7E-4 attached).

TOTAL $\quad(9$ pits) $\quad \$ 13,500,000$

\section{$\mathrm{DB} \backslash 3600 . \mathrm{DCN}$}


FLUOR DANIEL NORTHNEST, INC, NUAATEC IIANFORD CORPORATION JOB NO. EZOLA4

EILE NO. Z4JTSAF
* tEST - TUTERACTIVE ESTIMATING *

CONCEPT 2 - VEIICLE BASED KASTE RETRIEVA $S T U D Y$ T $T$ O

PUMCROS
PAGE 7 OF 20

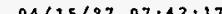

This

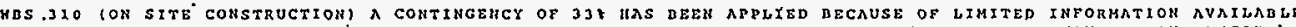
ON THE RADIATIOH LEVELS THAT KILL DE EHCOUNTERED DURINO PIPE INSTALLATXON, RIT MODIFICATIONS AHD DECOU TAMINATION, DIT MODIFICATIONS. AHD UNBERGROUAD ODSTRUCTIOHS TIAT MAY BE EHCOUNTERED DURINA CONSTRUCTION. THE ENHACED SLUICER COST IS OASED UPOU VERDAL ALLOHANCES PROVIDEO BX TUE GHOLNERR AUD HITHOUT VEUDOR i 1 एuT.

6. ROUNDIUC

THE PROJECT COST.SUMMARY REPORT IS SUMMARIZED AND ADUUSTED/ROUHDED AS FOLLOHS

THE ESCALATED TOTAL COST COLUMR, COHTIHGENCY TOTAS COLUMA AKD TOTAL DOLLARS COLUMA SUD THE COLUMH SUBTOTALS ARE ADJUSTED/ROUNDED TO THE UEAREST \$1,00O/\$10.000. THE PROJECT TOTAL \$UMMARY LIHE TOTALS ARE ADJUSTED/ROUNDED TO THE HEAREST $\$ 10,000 / \$ 200,000$.

\section{REMARKS}

HAJOR ASSUMPTIONS HUICH HAVE DEEU MADE IU THE PREPARATIOH OF TUIS ESTIMATE ARE.AS FOLLOHS:

A.) TIE TEMPORARY CUIMGE ROOM TRXILER, MOBILE DRIHL RIG AND ASSOCIATED EQUTPMENT, VACUUM TRUCK TGUZZLERI, AND CRANES HILL DE FURUISUED TO THE PROJECT AT HO COST EXCEPT YOR THE SET UP COSTS.

D.) DURHOUT COSTS ARE WOT IUCLUDED IH THIS COST ESTIHATE DY DIRECTIOH OF PHAC. IF DURMOUT IS

ADOED ITS COST IS APPROXIMATELY \$2.5H AND IS BASED UPON AN ASSUMED IOAK READING AT THE UPPER SECTIOM OP

TILE CASANG NHD 25 ME AT THE LONER SECTION OP JHE CASIHG, IREF, C. C. MATLI. OTHER CONSTRUCTIOU HORK, TNSIDE

THE FARM FEHCE, HAS ESTIMATED AS lOMr. RAD LEVELS ADOVE $25 \mathrm{mE}$ IS HOT ANTICIPATED.

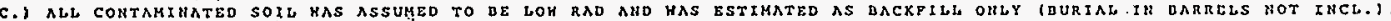

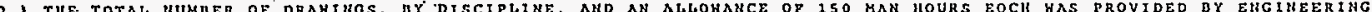

ITEMS THAT ARE NOT IHCLUDBO IN THIS COST ESTTHATE,

1. FLAMBAUE GAS. IT IS ASSUMED THAT THIS KAS COVERED TH THE H-320 DROJECT.

2. CONTROL ROOM TIE CONTROL ROOM PROVIDED IN $X-320$ HILI DE USED.

3. AFTER OPERATIONS IS COMPLETE. TUE EQUIPMENT HILL BE ABANDONED IU PLACE (EXCEPT ENHANCED SLUICER).

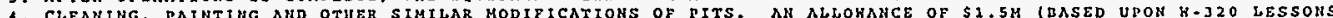

LEARUEDI PER PIT FOR DECOHTAMIUATION IS IHCLUDED.

5. TIE UVAC SYSTEM THAT K-320 INSTALLED IS NOT MODIFIED AHD IS HOT INCLUDED IN THIS COST ESTIMATE

6. SPARE PARTS

7.

1. PIPG ALLOKAUCES ARE FOR NORMAL PIPING AUD ARE NOT ASME, SECTION J. (U.STAMPED)

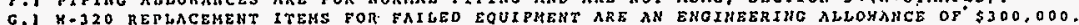

G.I H-320 REPLACEMENT ITEMS FOR FAILED EQUIPHENT ARE AN ENGIHEERIHG ALLOHANCE OF \$3DO,OOO.

EXIST PROJECT K-320 EXPERIENCED HIGHER MAHUOURS DUE TO POOR PIT CONDITIONS.

I.) AU ALPOHARE OF

I.) ESCALATION. IS DASED ONA MIDPOINT OF ALL STAGES OP COHSTRUCTION $\{1-1-39\}$. 
HNF-2693

Revision 1

\section{9. $\quad 102 \mathrm{~m}^{3}\left(3.600 \mathrm{ft}^{3}\right)$ BOP Mods/Installation}

The unit costs used in this section were taken from the FDNW Cost Normalization Unit Estimates (Manderbach 1997a).

\section{Waste Transfer Line Jumpers}

Six jumpers will be required in the new transfer pit to route the six lines coming from the 3 tanks (241-AX-101, 241-AX-102, and 241-AX-103).

Eight jumpers will be required for the pits in $\mathrm{AX}$ farm and two required at 241-AY-102.

TOTAL JUMPERS REQUIRED

TOTAL COST
$16 @ \$ 56,000$ ea

$\$ 896,000$

\section{Cover Block Removal}

Remove the cover blocks from the eight pits in AX farm (3 on each tank)

Remove/replace the cover blocks from the pump pit on 241-AY-102 for replacement of the pump due to radiation damage and the sluice pit for core drilling.

TOTAL COVER BLOCKS REMOVED $10 @ \$ 77,300$ ea

TOTAL COST $\$ 773,000$

\section{Cover Block Fabrication}

Fabricate and install new cover blocks for the eight pits in AX farm ( 3 each on 241-AX-101, 241-AX-103, and 2 each on 241-AX-102).

TOTAL COVER BLOCKS FABRICATED $8 @ \$ 102,500$ ea

TOTAL COST $\$ 820,000$

\section{Cover Block Disposal}

Dispose of the eight cover blocks removed from the pits in AX farm ( 3 on each tank).

TOTAL COVER BLOCKS DISPOSED

TOTAL COST
$8 @ \$ 54,800$ ea

$\$ 438,000$ 
HNF-2693

Revision 1

Greenhouse Setup/Teardown

Setup and teardown of greenhouses and shield walls on the eight pits in AX farm and two pits at 241-AY-102.

TOTAL GREENHOUSE SETUP/TEARDOWN $10 @ \$ 79,400$ ea

TOTAL COST $\$ \$ 794,000$

\section{Pit Core Drill} lines.

Core drill the 8 pits in AX farm and two pits at 241-AY-102 for the waste transfer

TOTAL CORE DRILLS

TOTAL COST
$10 @ \$ 29,200$ ea

$\$ 292,000$

\section{Concrete Pads}

Install concrete mounting pads at the $3 \mathrm{AX}$ farm tanks. Assume $9.3 \mathrm{~m}^{2}\left(100 \mathrm{ft}^{2}\right)$ total at each tank.

TOTAL CONCRETE PADS

TOTAL COST

$$
\begin{gathered}
27.9 \mathrm{~m}^{2} @ \$ 860 \mathrm{~m}^{2}\left(300 \mathrm{ft}^{2} @ \$ 79 \mathrm{ft}^{2}\right) \\
\$ 24,000
\end{gathered}
$$

\section{CCTV Installation/Removal}

Install CCTV units in the three AX farm tanks.

TOTAL CCTV INSTALLATIONS

TOTAL COST
$3 @ \$ 52,000$ ea

$\$ 156,000$ 
HNF-2693

Revision 1

\section{1-AY-102 Pump Replacement}

Replace the supernate pump in 241-AY-102 (due to radiation damage). The cover block removal, pump removal, and greenhouse setup/teardown are covered in the previous items. Assume pump disposal cost are comparable to cover block disposal costs from Manderbach (1997a).

241-AY-102 PUMP INSTALLATION

241-AY-102 PUMP DISPOSAL

TOTAL COST

TOTAL PHMC BOP COSTS
1 each@ @ $\$ 125,000$

1 each @ \$54,800

$\$ 179,000$

$\$ 4,372,000$

13600BOP 
HNF-2693

Revision 1

\section{0. $102 \mathrm{~m}^{3}\left(3,600 \mathrm{ft}^{3}\right)$ Safety and Permitting Costs}

The estimates for the safety and permitting costs are based on the HTI heel retrieval baseline estimate (pages $9,10,11$ attached). The AX farm retrieval safety efforts are considered to be approximately double those of the baseline estimate. Additionally, $\$ 750,000$ is included for Basis of Interim Operation (BIO) amendment activities. The estimate is also based on a 3-year project duration.

\begin{tabular}{|l|r|}
\hline \multicolumn{2}{|l|}{ Safety } \\
\hline Management (assuming 3-year duration) & 180,000 \\
\hline USQ & 15,000 \\
\hline HI\&E & 48,000 \\
\hline Safety Equipment Lists & 52,000 \\
\hline BIO amendment & 750,000 \\
\hline \multicolumn{1}{|c|}{ SUB TOTAL } & $\$ 1,045,000$ \\
\hline Permitting & 90,000 \\
\hline Management & N/A \\
\hline NEPA supplement analysis & 129,000 \\
\hline Air Permits (NOC) \$43k ea tank & 129,000 \\
\hline Air Permits (NOC) \$43k ea for the pits at each tank & 348,000 \\
\hline SUB TOTAL & $\$ 1,393,000$ \\
\hline TOTAL & \\
\hline
\end{tabular}

BIO $=$ Basis of Interim Operation

HI\&E $=$ Hazard identification and evaluation

NEPA = National Environmental Policy Act

NOC $=$ Notice of Construction

USQ $=$ Unreviewed Safety Question.

$D B \backslash 3600 . S A F$ 


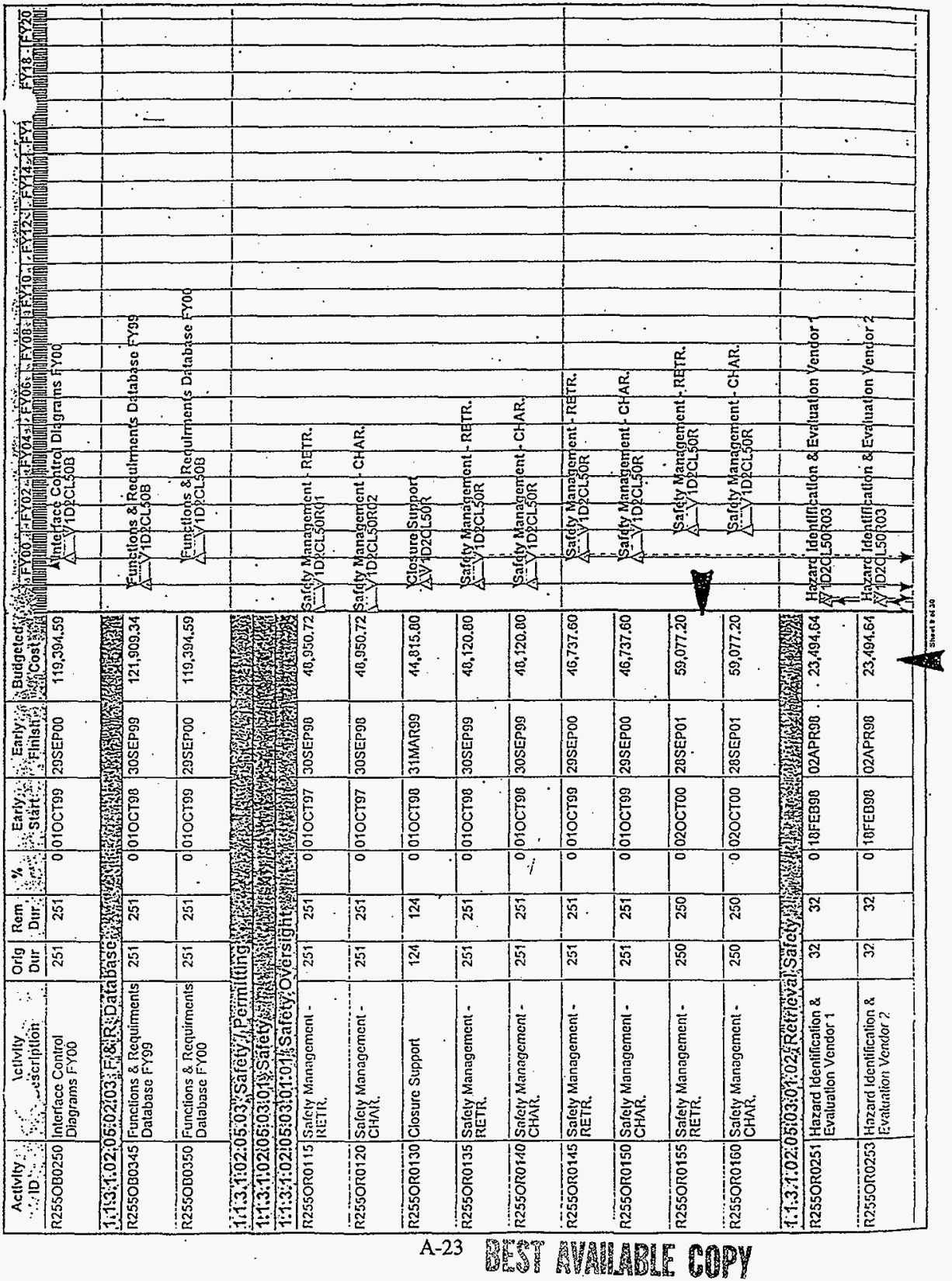


Revision 1

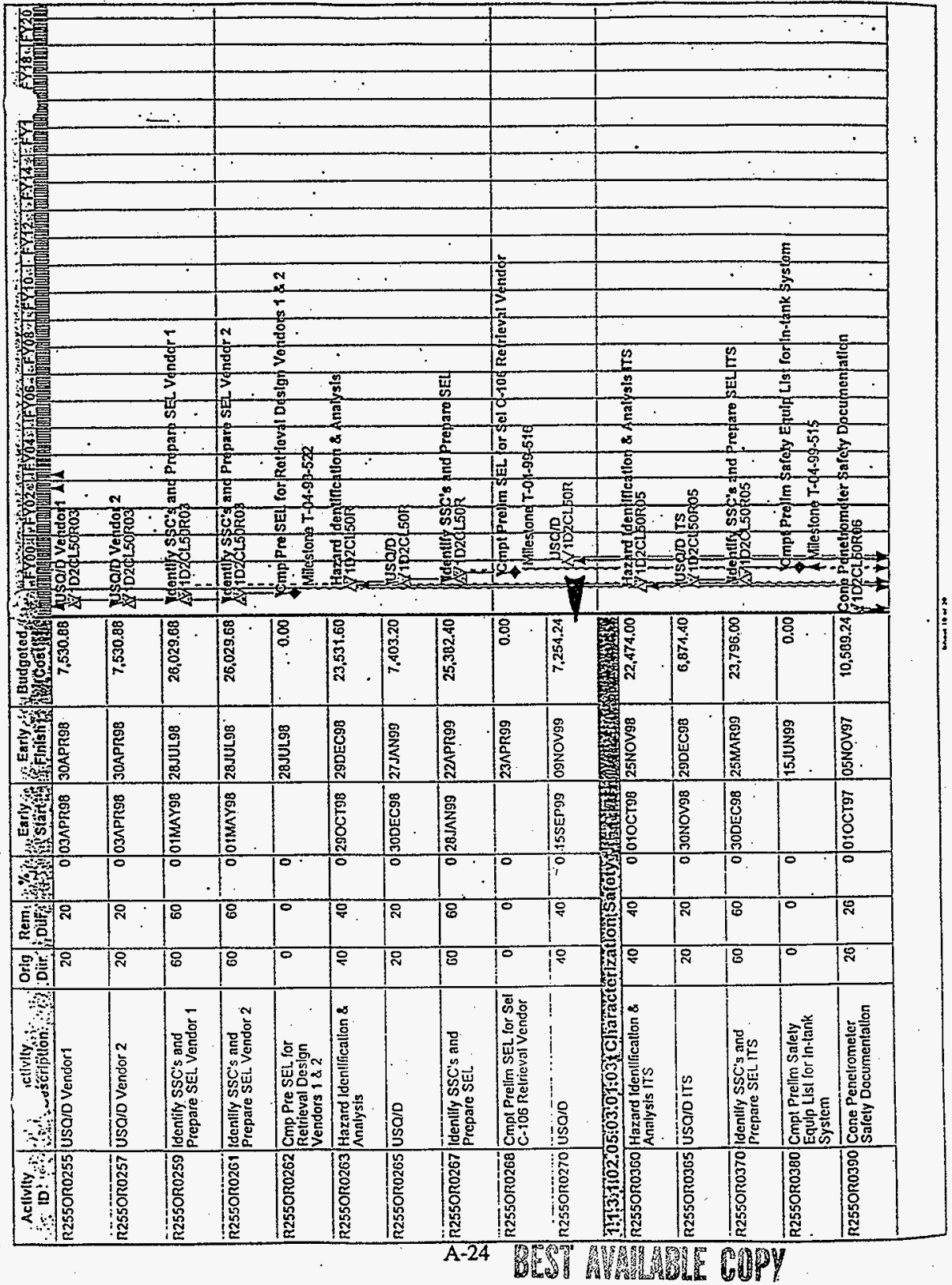


HNF-2693

Revision 1

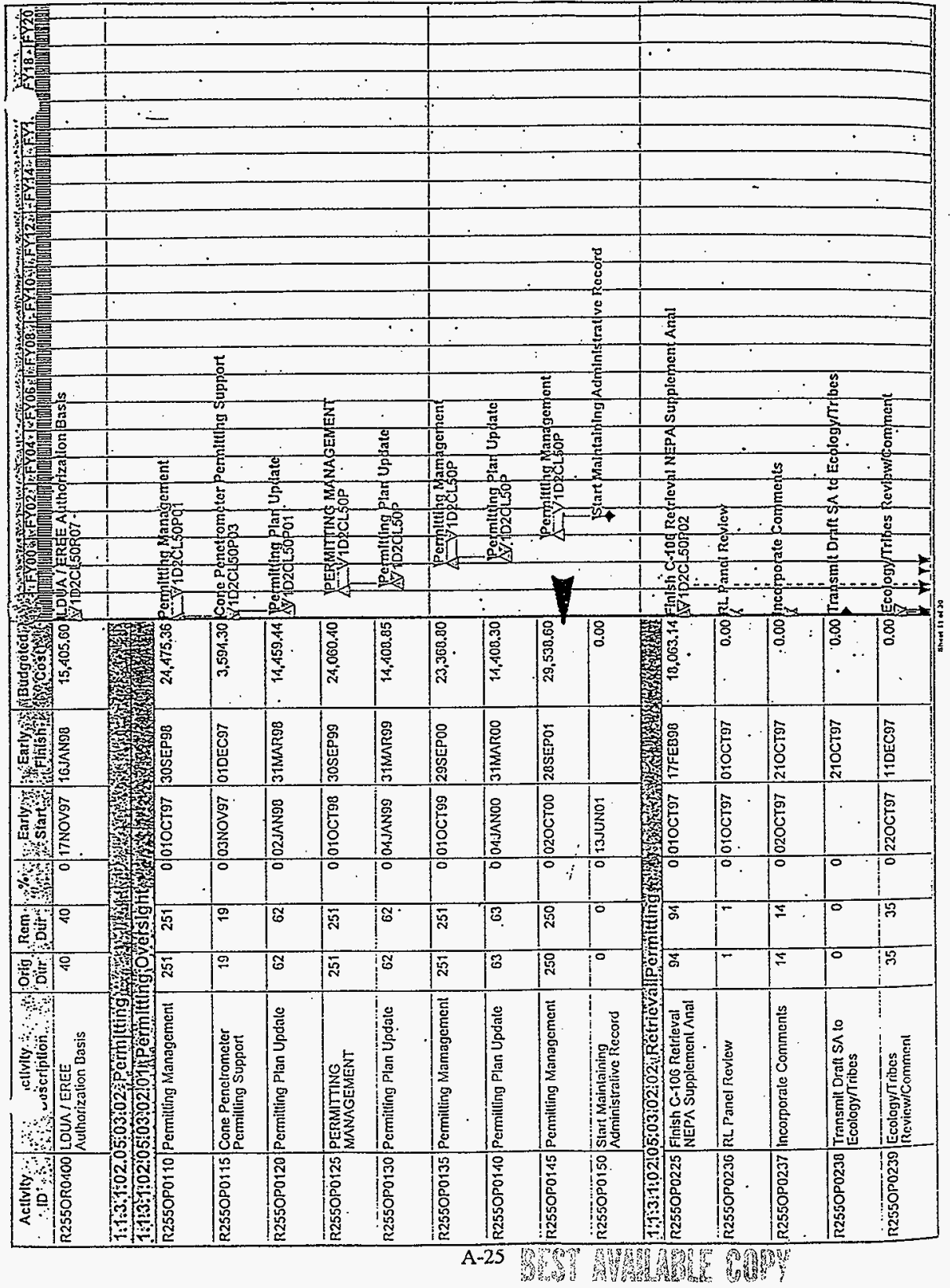


HNF-2693

Revision 1

\section{1. $102 \mathrm{~m}^{3}\left(3,600 \mathrm{ft}^{3}\right)$ Sluicer Operational Costs}

The estimate for operating the sluicer in tanks $241-\mathrm{AX}-101$ and $241-\mathrm{AX}-103$ is based on the data in tables A1 through A-5. Estimates are based on operating 7 days per week and 24 hours per day.

AX-101 Operational time $\quad 167.4$ days (23.9 weeks)

AX-103 Operational time 54.6 days $(7.8$ weeks)

5 person crew X 4 shifts X 40 hrs/wk X 31.7 weeks X $\$ 95 / \mathrm{hr}$

TOTAL

$\$ 2,409,000$

$\mathrm{DB} \backslash 3600.0 P S$ 
HNF-2693

Revision 1

\section{2. $102 \mathrm{~m}^{3}\left(3,600 \mathrm{ft}^{3}\right)$ Vehicle Operational Costs}

For the $102 \mathrm{~m}^{3}\left(3,600 \mathrm{ft}^{3}\right)$ case, the vehicle is used only in 241-AX-102.

The estimate for operating the vehicle in tank 241-AX-102 is based on the data in tables A1 through A-5.

AX-102 Operational Time 0.4 days ( 0.06 weeks)

The vendor labor costs are based on a 3 man crew, 4 shifts, and a 4 man home office support for 0.06 weeks of retrieval time (the labor through the ORR is included with in the installation costs)

There are an additional 4 weeks of time required for the dismantling and removal of the retrieval system for a total of 8 weeks.

16 persons @ $\$ 75 / \mathrm{hr} X 40 \mathrm{hrs} / \mathrm{wk}$ for 4.06 weeks

$\$ 195,000$

Per diem (12 persons @ $\$ 80 /$ day X 7 days/wk X 4;06 wk)

$\$ 27,000$

PHMC labor costs are for a 6 man crew, four shifts, for the 4.06 weeks retrieval and dismantling time.

24 persons @ \$95/hr X 40 hr/wk for 4.06 weeks

$\$ 370,000$

TOTAL

$\$ 592,000$

DB\3600VEH.OPS 
HNF-2693

Revision 1

\section{CALCULATED WASTE RETRIEVAL TIMES FOR AX TANK FARM ARE BASED ON THE FOLLOWING INITIAL WASTE VOLUME INVENTORIES.}
AX-101 750,000 gals.
AX-102 33,000 gals
AX-103 112,000 gals
AX-104 7,000 gals

The waste retrieval times are based on the rates shown in table A-5. The rates are based on the assumption that an offsite retrieval vendor will design, fabricate, and operate the vehicle retrieval system similar to the C-106 Heel retrieval system (PHMC personnel will operate the sluicing system). The retrieval rates are net rates and include maintenance downtime and operating efficiencies. The retrieval time is calculated assuming that the retrieval system is operated 24 hours per day, 7 days per week.

The vehicle system retrieval rates in table A-5 were developed in discussions with retrieval personnel working with the HTI C-106 Heel Retrieval vendor and are based on engineering judgement, vendor experience, and experience at the Savanna River "Gunnite and Associated Tanks" (GAAT) retrieval project. The Sluicing system retrieval times are based on past experience with sluicing the Single Shell Tanks in the 1960's and 1970's.

Table A-1. Retrieval Times for 241-AX-101 (Based on Table A-5).

\begin{tabular}{|l|c|c|c|}
\hline $\begin{array}{c}\text { Retrieval } \\
\text { Method }\end{array}$ & $\begin{array}{c}\text { Retrieved volume } \\
\text { (gals) }\end{array}$ & $\begin{array}{c}\text { Retrieval rate } \\
\text { (gal/min) }\end{array}$ & $\begin{array}{c}\text { Retrieval time } \\
\text { (days) }\end{array}$ \\
\hline Sluice & $750,000-27,000$ & 3.0 & 167.4 \\
\hline Sluice & $27,000-17,000$ & 2.5 & 2.8 \\
\hline Vehicle & $17,000-2,700$ & 0.5 & 19.9 \\
\hline Vehicle & $2,700-2,100$ & 0.5 & 0.8 \\
\hline Vehicle & $2100-270$ & 0.015 & 84.7 \\
\hline
\end{tabular}


Table A-2. Retrieval Times for 241-AX-102 (Based on Table A-5).

\begin{tabular}{|l|c|c|c|}
\hline Retrieval method & $\begin{array}{c}\text { Retrieved volume } \\
\text { (gals) }\end{array}$ & $\begin{array}{c}\text { Retrieval rate } \\
\text { (gal/min) }\end{array}$ & $\begin{array}{c}\text { Retrieval time } \\
\text { (days) }\end{array}$ \\
\hline Vehicle & $33,000-27,000$ & 10.0 & 0.4 \\
\hline Vehicle & $27,000-17,000$ & 6.5 & 1.1 \\
\hline Vehicle & $17,000-2,700$ & 0.5 & 19.9 \\
\hline Vehicle & $2,700-2,100$ & 0.5 & 0.8 \\
\hline Vehicle & $2100-270$ & 0.015 & 84.7 \\
\hline
\end{tabular}

Table A-3. Retrieval Times for 241-AX-103 (Based on Table A-5).

\begin{tabular}{|l|c|c|c|}
\hline Retrieval method & $\begin{array}{c}\text { Retrieved volume } \\
\text { (gals) }\end{array}$ & $\begin{array}{c}\text { Retrieval rate } \\
\text { (gal/min) }\end{array}$ & $\begin{array}{c}\text { Retrieval time } \\
\text { (days) }\end{array}$ \\
\hline Sluice & $112,000-27,000$ & 3.0 & 54.6 \\
\hline Sluice & $27,000-17,000$ & 2.5 & 2.8 \\
\hline Vehicle & $17,000-2,700$ & 0.5 & 19.9 \\
\hline Vehicle & $2,700-2,100$ & 0.5 & 0.8 \\
\hline Vehicle & $2100-270$ & 0.015 & 84.7 \\
\hline
\end{tabular}

Table A-4. Retrieval Times for 241-AX-104 (Based on Table A-5).

\begin{tabular}{|l|c|c|c|}
\hline $\begin{array}{c}\text { Retrieval } \\
\text { method }\end{array}$ & $\begin{array}{c}\text { Retrieved volume } \\
\text { (gals) }\end{array}$ & $\begin{array}{c}\text { Retrieval rate } \\
\text { (gal/min) }\end{array}$ & $\begin{array}{c}\text { Retrieval time } \\
\text { (days) }\end{array}$ \\
\hline Vehicle & $7,000-2,700$ & 0.5 & 6.0 \\
\hline Vehicle & $2,700-2,100$ & 0.5 & 0.8 \\
\hline Vehicle & $2100-270$ & 0.015 & 84.7 \\
\hline
\end{tabular}


HNF-2693

Revision 1

Table A-5. AX Farm Assumed Retrieval Rates.

(Gallons per minute)

\begin{tabular}{|c|c|c|c|c|}
\hline \multirow{2}{*}{$\begin{array}{c}\text { Waste volume } \\
\text { (gal) }\end{array}$} & \multicolumn{2}{|c|}{ Salt cake } & \multicolumn{2}{c|}{ Sludge } \\
\cline { 2 - 5 } & PPS & Vehicle & PPS & Vehicle \\
\hline 27,000 & 3.0 & $10^{(1)}$ & 3.0 & $10^{(1)}$ \\
\hline $\begin{array}{c}27,000 \\
\text { to } \\
17,000\end{array}$ & 2.5 & 6.5 & 2.5 & \\
\hline $\begin{array}{c}17,000 \\
\text { TO } \\
2700\end{array}$ & $0.25^{(2)}$ & 0.5 & $0.25^{(2)}$ & 0.5 \\
\hline $\begin{array}{c}2,700 \\
\text { to } \\
2,100\end{array}$ & 0.0 & 0.5 & & 0.5 \\
\hline $\begin{array}{c}2100 \\
\text { TO } \\
270\end{array}$ & 0.0 & 0.015 & 0.0 & 0.5 \\
\hline
\end{tabular}

${ }^{1}$ Vehicle used above 27,000 gal only on AX-102 (assumed leaker).

${ }^{2}$ For Past Practice Sluicing (PPS), the retrieval rate in the AX farm tanks drops to zero at 5000 gallons of residual waste due to the "shadow effect" of the air lift circulators and inefficiencies at low waste volumes.

${ }^{3} 3600 \mathrm{ft}^{3}=27,000$ gal; $360 \mathrm{ft}^{3}=2,700$ gal; $36 \mathrm{ft}^{3}=270$ gal.

${ }^{4}$ Due to lack of experience with sluicing salt cake at Hanford, the rate of salt cake retrieval is assumed to be the same as for sludge.

${ }^{5}$ The residual sluicing heel achieved in the 1970's (using 3 sluicers) exceeded $10.2 \mathrm{~m}^{3}\left(360 \mathrm{ft}^{3}\right)$ in all four AX farm tanks. 
HNF-2693

Revision 1

\section{APPENDIX B}

\section{COST ESTIMATE DETAILS FOR $10.2 \mathrm{~m}^{3}\left(360 \mathrm{ft}^{3}\right)$ RESIDUAL WASTE LEVELS}


HNF-2693

Revision 1

This page intentionally left blank.

B-2 
HNF-2693

Revision 1

\section{APPENDIX B}

\section{$10.2 \mathrm{~m}^{3}\left(360 \mathrm{ft}^{3}\right)$ COST DETALS}

Retrieval to $10.2 \mathrm{~m}^{3}\left(360 \mathrm{ft}^{3}\right)$ Residual Waste--Cost Summary. (2 Sheets)

\begin{tabular}{|l|l|r|}
\hline & \multicolumn{1}{|c|}{ Task description } & \multicolumn{1}{|c|}{ Cost } \\
\hline 1 & LLCE removal of tank equipment & $2,818,000$ \\
\hline 2 & $\begin{array}{l}\text { Procurement and installation of sluicing systems and equipment for } \\
\text { tanks 241-AX-101 and 241-AX-103 }\end{array}$ & $22,446,000$ \\
\hline 3 & Design/fabricate/install control room for sluicers & 204,000 \\
\hline 4 & Purchase vehicle retrieval system and install in all 4 AX farm tanks & $11,442,000$ \\
\hline 5 & $\begin{array}{l}\text { Design/fabricate/install HVAC system for tanks 241-AX-101, 102, } \\
103, \text { and 104. }\end{array}$ & $1,082,000$ \\
\hline 6 & $\begin{array}{l}\text { Design/install approximately 610 m (2,000 ft) of 10-cm (4-in. diameter } \\
\text { waste transfer lines between 241-AY-102 and 241-AX-101, 102, 103, } \\
\text { and 104 }\end{array}$ & 980,000 \\
\hline 7 & Design/install new waste transfer jumper pit on west side of AX farm & 334,000 \\
\hline 8 & $\begin{array}{l}\text { Decontaminate and clean out 11 pits in AX and AY farms based on } \\
\text { W-320 experience. }\end{array}$ & $16,500,000$ \\
\hline 9 & PHMC BOP modifications/installations & $5,343,000$ \\
\hline 10 & Safety and Permitting & $1,393,000$ \\
\hline 11 & Sluicing Operational Costs & $2,470,000$ \\
\hline 12 & Vehicle Operational Costs & $3,699,000$ \\
\hline & TOTAL & $68,711,000$ \\
\hline
\end{tabular}

BOP $=$ Balance of plant

CCTV $=$ Closed-Circuit Television

HVAC $=$ Heating, ventilating, and air conditioning

LLCE $=$ Long-Length Contaminated Equipment

PHMC $=$ Project Hanford Management Contractor

$\mathrm{TBD}=$ To be determined. 
HNF-2693

Revision 1

Contingency and escalation are assumed to be the same as used by FDNW in the preparation of the Project Design Concepts (May 1997). These are as follows:

Escalation is 5.3 percent for FY 1999 through FY 2006 (8 years) for a total escalation of 51.2 percent

32 percent contingency

TOTAL RETRIEVAL COST $\$ 68,711,000 \times 1.512 \times 1.32$

$=\$ 137,136,000$

$\mathrm{DB} \backslash 360-\mathrm{TBL}$ 
HNF-2693

Revision 1

\section{1. $\quad 10.2 \mathrm{~m}^{3}\left(360 \mathrm{ft}^{3}\right)$ Long-Length Contaminated Equipment Removal}

There are 6 pieces of Long-Length Contaminated Equipment (LLCE) that will be removed from the tank pits in AX farm. These will be removed with the existing LLCE system and packaged for burial or disposal as required.

The slurry pump in 241-AY-102 requires removal for replacement due to radiation damage.

In addition, one of the sluicers in 241-AX-101 and 241-AX-103 will need to be removed to provide access for the vehicle.

The estimated cost for the setup of the LLCE, removal of the item from the waste tank, packaging, and burial/storage is $\$ 418,000$ for the initial item based on Manderbach (1997a). Costs for subsequent items are $\$ 300,000$ each.

\begin{tabular}{|l|r|}
\hline Tank 241-AY-102 slurry pump removal & $\$ 418.000$ \\
\hline Tank 241-AX-101 pit 01A steam coil & $\$ 300,000$ \\
\hline Tank 241-AX-101 pit 01B Sluicer & $\$ 300,000$ \\
\hline Tank 241-AX-102 pit 02A Sluicer & $\$ 300,000$ \\
\hline Tank 241-AX-102 pit 02B Pump & $\$ 300,000$ \\
\hline Tank 241-AX-103 pit 03A Sluicer & $\$ 300,000$ \\
\hline Tank 241-AX-104 pit 04A Sluicer & $\$ 300,000$ \\
\hline Remove 241-AX-101 new sluicer for vehicle access & $\$ 300,000$ \\
\hline Remove 241-AX-103 new sluicer for vehicle access & $\$ 300,000$ \\
\hline TOTAL (for $10.2 \mathrm{~m}^{3}$ [360 $\mathrm{ft}^{3}$ ] case) & $\$ 2,818,000$ \\
\hline
\end{tabular}

$\mathrm{DB} \backslash 360 \mathrm{LLCE}$ 
HNF-2693

Revision 1

\section{2. $\quad 10.2 \mathrm{~m}^{3}\left(360 \mathrm{ft}^{3}\right)$ Sluicing Equipment fabricate/installation costs}

The cost estimate for the design/fabrication and installation of sluicing systems on tanks 241-AX-101 and 241-AX-102 is based on the enhanced sluicing cost estimate for 241-C-106 prepared by FDNW for Job no. E20144 (file no. Z437SAE2) (summary sheet attached). The estimate was modified as detailed below to more accurately reflect the AX farm conditions.

The Total projected cost estimate without escalation or contingency is $\$ 34,140,000$ including site allocations. The following items were removed from the estimate as redundant or not applicable:

\begin{tabular}{|l|r|}
\hline Regulatory compliance & $1,281,000$ \\
\hline Accident analysis & 650,000 \\
\hline Pump pit 241-C-06A & $2,303,000$ \\
\hline Heel pit 241-C-06B & $1,967,000$ \\
\hline Sluice pit 241-C-06C & $1,922,000$ \\
\hline Enc'd pipe pump to heel pit & 298,000 \\
\hline Enc'd pipe heel to sluice pit & 223,000 \\
\hline Heel jet removal & 618,000 \\
\hline Sluicer removal & 594,000 \\
\hline Vendor perform retrieval & $2,000,000$ \\
\hline Vendor Demobilization & 500,000 \\
\hline Ready tank for closure & $2,500,000$ \\
\hline SUB-TOTAL & $14,856,000$ \\
\hline
\end{tabular}

The following items were added to the estimate to account for operation in two tanks:

Vendor equipment $2,000,000$

Vendor equipment installation

$1,162,000$

SUB-TOTAL

$3,162,000$

TOTAL $(34,140,000+3,162,000-14,856,000)=\$ 22,446,000$ 
FLUOR DANIEL WORTHHEST, IUC. NUMATEC HANFORD CORPORATION JOB NO. 220144

FILE HO. Z4J75AEZ
- test - interactive estimating . CONCEPT 1 - EMHANCEO SLUTCINC ORDER OF MACNITUDE

PHMCROL - PROJPCT COST SUHMAR
PNGE I OF 20

$7.51,45$

BY TLH, JJM, RWO, CDL

i

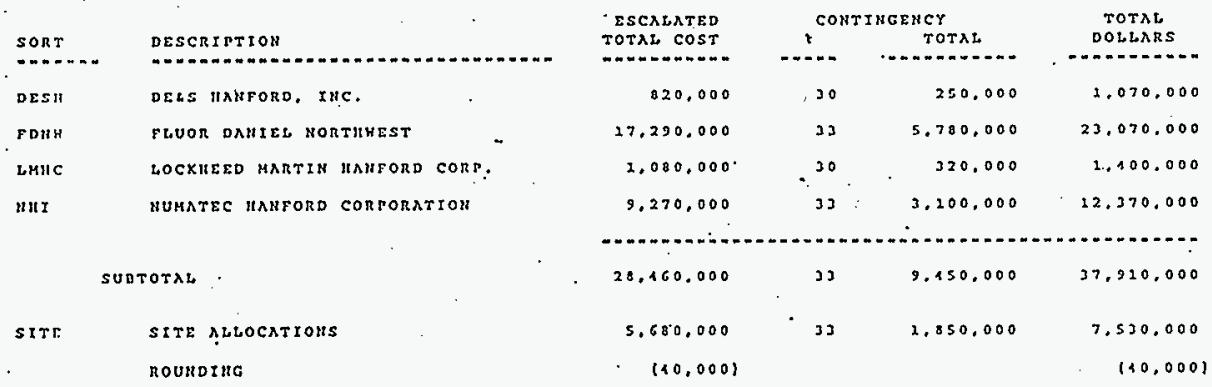

TOTA, PROJECT COST (TPC)

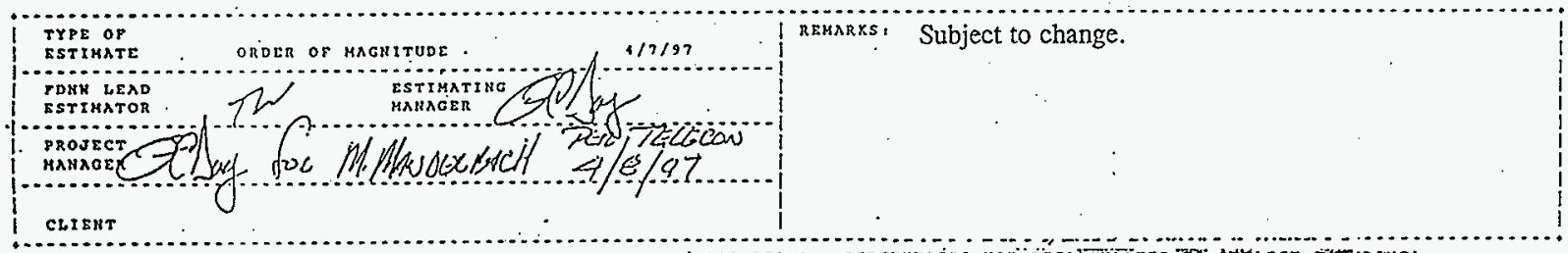

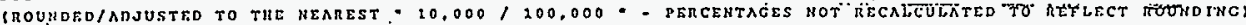


HNF-2693

Revision 1

\section{3. $\quad 10.2 \mathrm{~m}^{3}\left(360 \mathrm{ft}^{3}\right)$ Sluicer Control Room}

The estimated cost for the control room/lunch room is taken from the $1994 \mathrm{~W}-320$ estimate (Job no. W-320/ER4319 page 23 attached). One control room for the systems used in tanks $241-\mathrm{AX}-101$ and $241-\mathrm{AX}-103$ is adequate. This control room would be located outside the tank farm boundaries.

The W-320 control room was not installed (a mobile office was modified) so the costs for the control room are not included in the later estimates.

From page 23 of the estimate (rounded) $\$ 204,000$

$\mathrm{DB} \backslash 360 . \mathrm{CNT}$ 
RAISER EUGIMEERS IMHFORO HESIIHGIIOUSE HAHFORO COHPAIY JOB HO. H०320/ER4318

FILE $\mathrm{OO}$ H32OPBOT

CODE/URS

DESCRIPTIOH

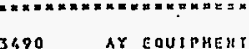

3510 IIYORAULIC TRAILER/SIROHGOACK

3580 CEURTIC EABRICATION

4212 CIITRL RH IUSTR. IHSTALLATION

421

4222

4223

4314

43 is

4322

4324

4330

4341

4343

4351

14352

4353

4354

COMTROL RH/LUIICII RH

CORE DRILLS

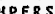

JICASEO PIIIC IUSTALLATIOUI

C- FARH IUSTRUMEIT AIR \& VEVT

C- FARH ELECTRICAL

MASF HOCX-UP

SLUICIIIG EOUIP.

CIIILLER SKID

PROCESS SKID

EXIIAUSY SYSIEH

FOG SUPRESSIOII SYS

DIRECTED AIR SYSIEH

EXISTIUG AIR IULET HOD'S

HISC.PADS

PIT SLEEVE/ EMOEDS

JUHPERS

PIT OACKEILL

EXCAVATIOH. PIPIHG

EHCASEO PIPIUG TIISTALLATIOUI

SLUICIUC EOUIBHE C. 106

COLD TESTIIIG

FABRICATIOHIIISTALLATIOU

GEHERAL COIISTRUCTLOII SUPPORT-ERS

COHTA.IHER YRAILER FAB CTC

GEHERAL COLSTRUCTION SUPPORT-SLUICE

GEHERAL L TECH. SERVICES-SLUICIUG
TRAIISFER LIHE

HISC. IUSTRUAENTATIOH

DACKFILL PIPIIIG

AY-FARH ELECTRICAL

IVAC SKIO PROCUREHEHT

* HEST - IHTERACTIVE ESTIHATIUG * * TAIIX 241-C-106 SLUICIXG REVISIOII H DOE RO - COST CODE ACCOUHT SUARARY

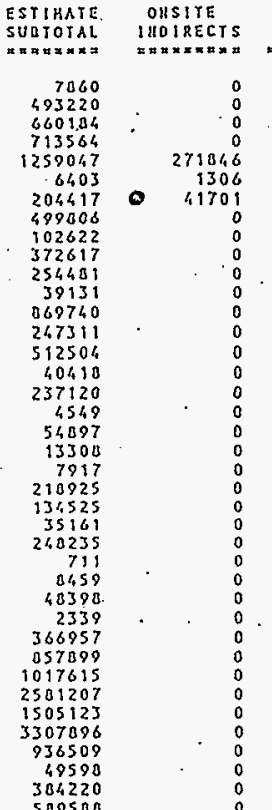

TOTAL 700 SPECIAL EOUIP/PROCESS SYSYEN $197 B 3677$
PAGE 23 OF 32

DATE 10 /

BY GDC/JPM/OXIIVCOL/XDE

\section{1}

TOTAL COHTIHGEHCY

TOTAL

ESCALATIOH

TOTAL

$\operatorname{loth}_{x \rightarrow \infty x=0}$

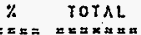

TOTAL DOLLAXS

0.00

$4,706020.0 .00$

660184

1530093

0.00
1.60

1.60

7709

246110

490006

102622

254401

30131

060740

247311

512504

40410

237120

4549
54897

13300

7917

210925

134525

35161
240235

711
8459

01,59
40398

366957

857899

25171207

1505123 .

3307096

936509

938508
1,84920

304220

.509508

1.60

3.61

3.61

3.61

3.61

$3.61 \quad 3412$

3.61 . 3920

$3.61 \quad 18501$

3.61

3.61

3.61

3.61

3.61

3.09

3.09

3.09

3.09 .

3.09

3.89

2.46

$2.46 \quad 25033$

0.17

0.14

2.17

0.00

2.17

1.77

164

1981

481
206

2516
5233

1360

9657

20
329

1083

4276

1740

4597
20322

0330

12795

7360
493220
660104
724901

660104
724901

1555307
7033

250056

517349

306326

263660

263660
40543

901137

256239

531005

41077
245600

4713

56878

13709

8203

227441

36530

257.892

730

50281

2430

301231

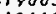

1012640

1506072

3312693

956331
49590

49590
392558

602383

356343

$20454072^{\circ} 17$
54440

299448

7127

71099

10254

204364

181605

335259

960

65365

3159

4.803

3199048

1662439

3630864

1140197

54550
471069

.722858

24039443 
HNF-2693

Revision 1

\section{4. $\quad 10.2 \mathrm{~m}^{3}\left(360 \mathrm{ft}^{3}\right)$ Vehicle Retrieval System costs}

\section{Vendor Costs}

The vendor cost estimate is based on the two vendor systems currently being designed for the retrieval of the heel in tank 241-C-106. This also assumes that the same type of service contract will be used to procure the retrieval systems for the AX farm as is being used for the procurement of the 241-C-106 vehicle retrieval system.

\section{Vendor supplied system/equipment}

Design, fabrication, testing, and delivery of a vehicle based retrieval system ready to install in the AX farm (based on discussions with HTI 241-C-106 Heel Retrieval System Engineers).

\section{Pre-operational work at $\mathbf{A X}$ farm}

$\$ 5,500,000$

ORR, training, and acceptance testing based on 6 month duration. Three person vendor crew, four shifts, and four person home office support on one shift.

$$
\begin{array}{lr}
\text { Labor (16 persons @ } \$ 75 / \mathrm{hr} \text { for } 24 \text { weeks) } & \$ 1,152,000 \\
\text { Per diem (16 persons } @ \$ 80 / \text { day for } 24 \text { weeks) } & \$ 30,700
\end{array}
$$

Warehouse and office rental in the Tri-Cities area.

Eighteen month duration based on the use of one vehicle that is moved tank to tank

$\$ 90,000$

Sub-total

$\$ 6,772,000$

\section{PHMC Bid and Award}

Based on HTI 241-C-106 Heel Retrieval System costs

$\$ 200,000$

PHMC Contract Management

Based on HTI 241-C-106 Heel Retrieval System costs

$\$ 400,000$ 
HNF-2693

Revision 1

\section{PHMC ORR/ATP}

Based on HTI 241-C-106 Heel Retrieval System costs

$\$ 400,000$

Three additional ATP/OTPs after vehicle moved

$\$ 300,000$

Sub-total

$\$ 1,300,000$

\section{Installation Costs}

The estimated cost to install a vehicle based retrieval system in 241-AX-101, 102.103, and. 104 is assumed to be the same as for tank 241-C-106. The installation costs in 241-C-106 is from sheet 17 (attached) of the HTI baseline estimate. This does not include the costs to modify the farm/tank for acceptance of the vehicle system.

Four at

Sub-total

TOTAL
$\$ 842,500$ each

$\$ 3,370,000$

$\$ 11,442,000$

DB\360.VEH 
HNF-2693

Revision 1

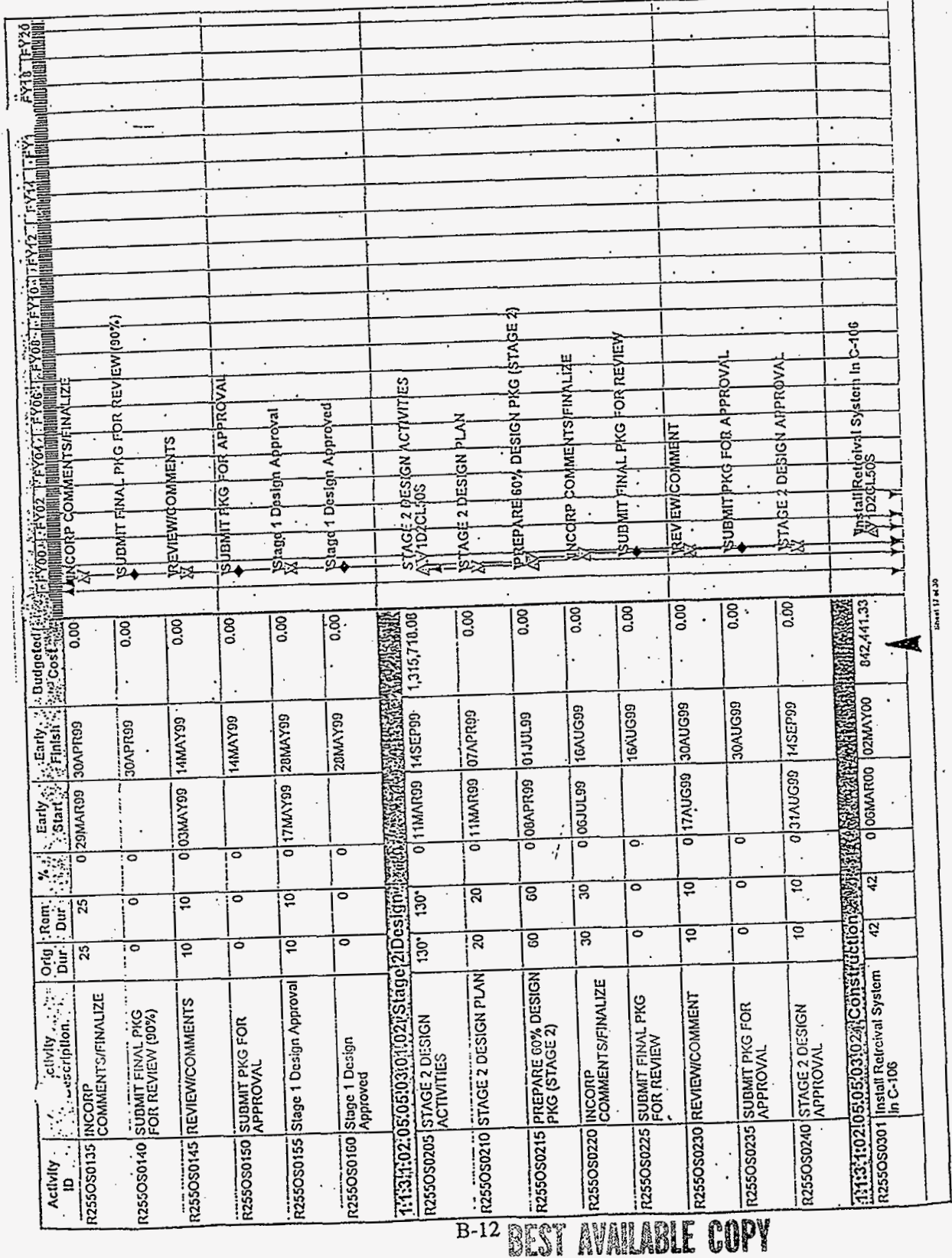


HNF-2693

Revision 1

\section{5. $\quad 10.2 \mathrm{~m}^{3}\left(360 \mathrm{ft}^{3}\right)$ HVAC System Design/Installation Costs}

The estimate for a new AX farm HVAC system is based on the FDNW W-320 HVAC skid estimate contained in file no. W320PDA4, job no. W-320/P7448M (page 14 attached). This is the same as for the $102 \mathrm{~m}^{3}\left(3,600 \mathrm{ft}^{3}\right)$ case with an additional $\$ 100,000$ to connect the system to 241-AX-104.

\begin{tabular}{|l|r|}
\hline AX Farm HVAC System for three tanks & $\$ 982,000$ \\
\hline Additional cost to connect to 241-AX-104 & $\$ 100,000$ \\
\hline TOTAL & $\$ 1,082,000$ \\
\hline
\end{tabular}

DB\360HVAC 
XAISER SUGTHERA HAHFORD

HESTINGHOUSE HAHFORD COMPAHY

SOB HO. H-320/874RAH

FILE YO. H32OROA

NDS DESCRIPTIOU

450980 process nuitoing procutruent

ISOARC CHI LESH SXID PrOCUREHEMT

SURTOTAL 1502 IVAC SXID FROCUREMEUT$$
\text { -. }
$$

4S2OAD PURCIIASE THUR

ISLOAC ELECTRICAL FOUIFHEAT PROCURFHEAT

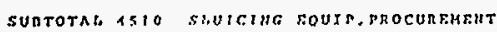

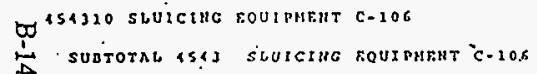

SUDTOTAL 15 EXPEHSE PROCUREMENT.

161500 TIT OFCOH. HOCK-UR

461510 PIT DECOH C-105 FARH $\quad \therefore .329216$

161530 SIT DECOH - AY-103 EARY

suntotat 4615 Mit oncos

SUETOTAL 16 TIT DECON

170000 CONSTRUCTION SERVICES - CtD

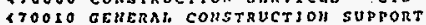

suntorst 1700 constnuction sigutces

177700 EOUTRMEHT USAGE

177710 HANAGRMEHT SUPFORT: FOR CONSTR.

$177720 \mathrm{CF}$ SUPFORT

177730 QUALITY SUPPORT

SUDTOTAL ETTJ GENERAL TECH, SERVICES.

SUATOTAL 7 CONSTRUCTzOH SERVICRS
* iEst - intBRnctive Estimatimo -

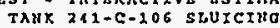

gOt PRELYHTNARY ESTINATE

DOE, RO2 - NORX DREAKDOHA STRUCTURE SUMHARY

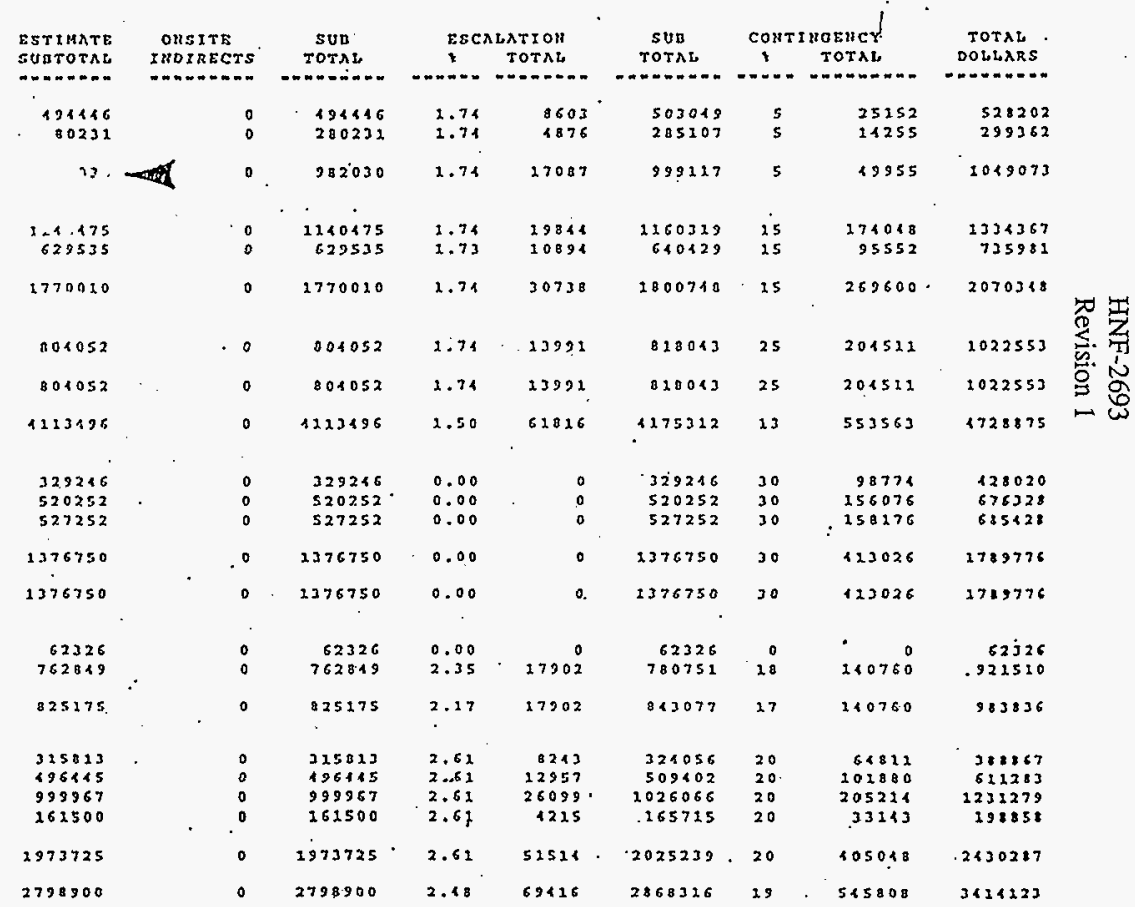

rias. is or 35

DATE O7/25/95 $15,21,06$

DY XE/DH/JM/LR/CH/RO/XR 
HNF-2693

Revision 1

\section{6. $\quad 10.2 \mathrm{~m}^{3}\left(360 \mathrm{ft}^{3}\right)$ Waste Transfer Line}

\begin{tabular}{|c|c|}
\hline Description & Length \\
\hline \multicolumn{2}{|l|}{ 241-AY-102 } \\
\hline Pit $02 \mathrm{~A}$ to new valve pit & $76 \mathrm{~m}(250 \mathrm{ft})$ \\
\hline Pit $02 E$ to new valve pit & $72 \mathrm{~m}(235 \mathrm{ft})$ \\
\hline \multicolumn{2}{|l|}{ 241-AX-101 } \\
\hline Pit 01A to new valve pit & $67 \mathrm{~m}(220 \mathrm{ft})$ \\
\hline Pit 01B to new valve pit & $61 \mathrm{~m} \mathrm{(200 \textrm {ft } )}$ \\
\hline Pit 01D to new valve pit & $56 \mathrm{~m}(185 \mathrm{ft})$ \\
\hline \multicolumn{2}{|l|}{ 241-AX-102 } \\
\hline Pit $02 \mathrm{~A}$ to new valve pit & $58 \mathrm{~m}(190 \mathrm{ft})$ \\
\hline Pit $02 B$ to new valve pit & $50 \mathrm{~m}(165 \mathrm{ft})$ \\
\hline \multicolumn{2}{|l|}{ 241-AX-103 } \\
\hline Pit 03A to new valve pit & $38 \mathrm{~m}(125 \mathrm{ft})$ \\
\hline Pit $03 C$ to new valve pit & $41 \mathrm{~m} \mathrm{(135 \textrm {ft } )}$ \\
\hline Pit $03 \mathrm{D}$ to new valve pit & $29 \mathrm{~m}(95 \mathrm{ft})$ \\
\hline \multicolumn{2}{|l|}{ 241-AX-104 } \\
\hline Pit 04A to new valve pit & _m $(90 \mathrm{ft})$ \\
\hline Pit 04D to new valve pit & $21 \mathrm{~m}(70 \mathrm{ft})$ \\
\hline TOTAL LINE LENGTHS IN FEET & $598 \mathrm{~m}(1,960 \mathrm{ft})$ \\
\hline COST & $\$ 980,000$ \\
\hline
\end{tabular}

Note 1: Fabrication and installation cost for the waste transfer line is $\$ 3,279 / \mathrm{m}(\$ 1,000 / \mathrm{ft})$ for a double line.

Note 2: Each pit above requires core drill and nozzle installation, i.e., 12 each for the $10.2 \mathrm{~m}^{3}\left(360 \mathrm{ft}^{3}\right)$ case. 
HNF-2693

Revision 1

\section{7. $10.2 \mathrm{~m}^{3}\left(360 \mathrm{ft}^{3}\right)$ Pit Design/Installation Costs}

The estimate for a new $\mathrm{AX}$ farm above grade transfer line (jumper) pit is based on the pit cover block fabrication and caisson/slab support for the manipulator arm costs contained in the Cost Normalization Unit Estimates (Manderbach 1997a). Assume same cover block costs and that the pit will cost the same as the manipulator slab.

Cover block

Pit

TOTAL
$\$ 102,000$

$\$ 232,000$

$\$ 334,000$

DB\360.PIT 
HNF-2693

Revision 1

\section{8. $\quad 10.2 \mathrm{~m}^{3}\left(360 \mathrm{ft}^{3}\right)$ Pit Decontamination Costs}

For the $10.2 \mathrm{~m}^{3}\left(360 \mathrm{ft}^{3}\right)$ case, 10 pits in $\mathrm{AX}$ farm and the pump pit at 241-AY-102 are used for the retrieval activities.

Discussed the condition and radiation levels in the pits with Dave Bragg in a Telecon $4 / 20 / 98$ as summarized below.

Dave is not aware on any record of the activities that have been carried out in the last 15 years in the pits. Dave indicated that the pits probably haven't been opened in the last 15-20 years. Dave has no information on the pits as compared to the 241-C-106 pits that were decontaminated for Project W-320. Dave stated that John W. Bailey might have some recollection of the $\mathrm{AX}$ farm retrieval sluicing activities and that he would be a good source to try. John Bailey indicated that the pits in AX farm should be in better condition that those in C Farm (the drains should work).

For the purposed of preparing this estimate, will assume that the pits are in comparable condition to the 241-C-106 pits. From the FDNW estimate for the Vehicle Based Retrieval System, Job no. E20144 (file Z437SAF2), the allocated cost for decontamination of the pits is $\$ 1,500,000$ each (page 7, item $7 \mathrm{E}-4$ attached).

TOTAL

(11 pits) $\$ 16,500,000$

DB $\backslash 360 . D C N$ 
FLUOR DAHIEL NORTIHEST, INC. HURATEC MAMFORD CORPORATIOH JOB HO. E20144

TILE $110.2137 S A Y^{2}$ $\because$ IEST - INTERACTIVE ESTIMATIHG * CONCEPT 2 - VEHTCHE BASED HASTE RETRTEVAL

$$
S T \text { T D Y T B O }
$$

PHRCROJ - ESTIIMATE BASIS SUEET.
PAGE 7 OF 26

DATE O4/15/37 O7:42:17

DY TLK, JJM, RHO, $C_{D}$

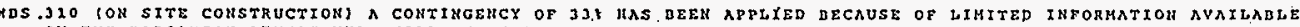
ON TUE RADIATION LEVELS TIITT HILI. DE EUCOUNTERED DURIMO PIPE INSTALLATION, PIT MODIEICATYOHS AND DECOHTAMIUATION, FIT MODIPICATIOUS, AHD UNDERGROUND ODS THE REIIARCEO SLUICER COST IS DASED UPON VERBAL ALLOH, InPUT.

6. ROUHDIHC

THE PROJECT COST SUMMARY REPOHT IS SUMMARTZED AND ADJUSTED/ROURDED AS FOLLOHS:

THE SSCALATED TOTAL COST COLUMH, COMTIHOEHCX TOTAL COLUMK AND TOTAL DOLLARS COLUMN SUR-TOTALS ARE SUMMARIZED GY COHTRACTOR.

THE COLUMH SUBTOTALS ARE ADJUSTED/ROUHDED TO THE HEAREST \$2.00O/\$10.0OO. THE PROJECT TOTA! SUMMARY LIHE TOTALS ARE

7. REHARXS

MAJOR ASSUHPTIOHS KUICI HAVE BEEM MADE IU THE PREPARATIOU OF THIS ESTIMATE ARE AS FOLLOHS:

A.) TIIE TEMPORARY CHANGE ROOH TRAILER, MOQILE DRILL RIO AND ASSOCIATED EQUIPMEUT, VACUUA TRUCK TCUZZLERJ, AND CRAHES HILL DE FURIISHED TO THE PROJECT AT HO COST EXCEPT FOR THE SET UP COSTS.

D. DUROUT COSTS ARE NOT INCLUDED UI THIS COST ESTIMATE BX DIRECTIOH OF DHMC. IE BURMOUT IS

ADDED ITS COST IS APPROXIMATELY \$2.5M AMD IS DASED UROU AH ASSUMED IOME READING AT THE UPDER SECTIOU OF

THE CASIHC AND $25 \mathrm{~mL}$ AT THE LOHER SECTION OF THE CASIHG, RREF. C.C. MATLI. OTHER CONSTRUCTION HORX. SHSIDE.

THE TARM FENCE. HAS ESTIMATED AS $10 \mathrm{mE}$. RAD LEVELS AROVE $25 \mathrm{mE}$ IS VOT MUTICIPATED.

C I TIE RARM FENCE, HAS ESTIMATED AS TOME. RAD DEVELS ADOVE

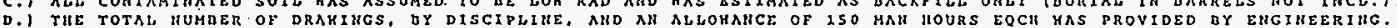

5. ITEMS THAT ARE HOT IMCLUDED IN THIS COST ESTIMATE.

1. FLAYMAULE GAS TT IS ASSUMED THAT TUS HAS COVERED IS THE H-JZO PROJECT.

1. CONTROD

2. CONTROL ROOM. THS CONTROL ROOM PROVIDED IH H-32O HILL DE USED

1. APTER OPERNT

- CLEAMIHG PAIHTXHE AHD OTHER SIMILAR MODIFICATIOHS

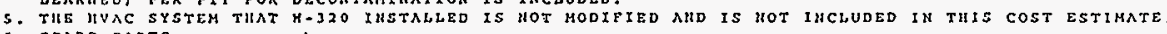

6. SPARE parts.

7. ADUITIOHAL REHOTE CAHERAS AS THS HAS THSTALLED DV H-J20.

F.1 PIPIUG ALLOKAHCES ARE POR HORMAL PIPIHC AUD ARE HOT ASME, SRCTIOH J (N-STAMPFD)

G.j K-320 RETLACEMEHT ITEMS FOR. EAILED EQUIFMENT ARE AN EHOIUEERTNO ALLOHAUCE OF $\$ 300,000$.

H.) EXISTIHG PIT COHDITIOHS ARE UHKHOHU AND THE HASH DOKN ALLOHAHCE OF $20 O M H$ IS OHLY AH ALLOKAHCE. TT SHOULO DE HOTEO

THAT PROJECT $\mathrm{H}-320$ EXPERIENCED HIGIER MAHHOURS. DUE TO FOOR PIT CONDITIONS.

I.) AN ALLOYAUCE OP APPROXYHATELY S.SM (BASED OU H-320 LESSONS LEARHEDI PER PIT FOR DECONTAMINATION IS INCLUOED.

J.) ESCALATIOU IS DASED OH A HIDSOINT OF ALL STAGES OP COHSTRUCTIOH $(4-2-99)$ 
HNF-2693

Revision 1

\section{9. $\quad 10.2 \mathrm{~m}^{3}\left(360 \mathrm{ft}^{3}\right)$ BOP Mods/Installation}

The unit costs used in this section were taken from the FDNW Cost Normalization Unit Estimates (Manderbach 1997a).

\section{Waste Transfer Line Jumpers}

Eight jumpers will be required in the new transfer pit to route the eight lines coming from the 4 tanks (241-AX-101, 241-AX-102, 241-AX-103, and 241-AX-104).

Ten jumpers will be required for the pits in $\mathrm{AX}$ farm and two required at 241-AY-102.

TOTAL JUMPERS REQUIRED

$20 @ \$ 56,000$ ea

$$
\text { TOTAL COST } \$ 1,120,000
$$

\section{Cover Block Removal}

Remove the cover blocks from the ten pits in AX farm (3 each on 241-AX-101 and 241-AX-103; 2 each on 241-AX-102 and 241-AX-104)

Remove/replace the cover blocks from the pump pit on 241-AY-102 for replacement of the pump due to radiation damage and the sluice pit for core drilling.

TOTAL COVER BLOCKS REMOVED $12 @ \$ 77,300$ ea

TOTAL COST $\$ 928,000$

\section{Cover Block Fabrication}

Fabricate and install new cover blocks for the ten pits in $\mathrm{AX}$ farm ( 3 each on 241-AX-101, 241-AX-103, and 2 each on 241-AX-102, 241-AX-104).

TOTAL COVER BLOCKS FABRICATED $10 @ \$ 102,500$ ea

$$
\text { TOTAL COST } \$ 1,025,000
$$

\section{Cover Block Disposal}

Dispose of the ten cover blocks removed from the pits in AX farm.

TOTAL COVER BLOCKS DISPOSED

TOTAL COST
$10 @ \$ 54,800$ ea

$\$ 548,000$ 
HNF-2693

Revision 1

\section{Greenhouse Setup/Teardown}

Setup and teardown of greenhouses and shield walls on the ten pits in AX farm and two pits at 241-AY-102.

TOTAL GREENHOUSE SETUP/TEARDOWN $12 @ \$ 79,400$ ea

TOTAL COST

$\$ 953,000$

Pit Core Drill

Core drill the 10 pits in $\mathrm{AX}$ farm and two pits at 241-AY-102 for the waste transfer lines.

TOTAL CORE DRILLS

$12 @ \$ 29,200$ ea

TOTAL COST

$\$ 350,000$

\section{Concrete Pads}

Install concrete mounting pads at the $4 \mathrm{AX}$ farm tanks. Assume $9.3 \mathrm{~m}^{2}\left(100 \mathrm{ft}^{2}\right)$ total at each tank.

TOTAL CONCRETE PADS $\quad 37.2 \mathrm{~m}^{2} @ \$ 850 / \mathrm{m}^{2}\left(400 \mathrm{ft}^{2} @ \$ 79 \mathrm{ft}^{2}\right)$

TOTAL COST $\$ 32,000$

\section{CCTV Installation/Removal}

Install CCTV units in the four AX farm tanks.

$\begin{array}{cc}\text { TOTAL CCTV INSTALLATIONS } & 4 @ \$ 52,000 \text { ea } \\ \text { TOTAL COST } & \$ 208,000\end{array}$


HNF-2693

Revision 1

\section{1-AY-102 Pump Replacement}

Replace the supernate pump in 241-AY-102 (due to radiation damage). The cover block removal, pump removal, and greenhouse setup/teardown are covered in the previous items. Assume pump disposal cost are comparable to cover block disposal costs from Manderbach (1997a).

241-AY-102 PUMP INSTALLATION

241-AY-102 PUMP DISPOSAL

TOTAL COST
1 each $@ \$ 125,000$

1 each@\$54,800

$\$ 179,000$

TOTAL PHMC BOP Modifications/Installations $\$ \$ 5,343,000$

1360BOP 
HNF-2693

Revision 1

10. $\quad 10.2 \mathrm{~m}^{3}\left(360 \mathrm{ft}^{3}\right)$ Safety and Permitting Costs

The estimates for the safety and permitting costs are based on the HTI heel retrieval baseline estimate (pages $9,10,11$ attached). The AX farm retrieval safety efforts are considered to be approximately double those of the baseline estimate. Additionally, $\$ 750,000$ is included for USQ amendment activities. The estimate is also based on a 3-year project duration.

Safety

Management (assuming 3-year duration) $\quad 180,000$

USQ

15,000

HI\&E

48,000

Safety Equipment Lists

52,000

BIO amendment

750,000

Sub-total

$\$ 1,045,000$

Permitting

Management

90,000

NEPA supplement analysis

N/A

Air Permits (NOC) $\$ 43 k$ ea tank

129,000

Air Permits (NOC) for the pits at each tank (\$43k ea)

129,000

Sub-total

$\$ 348,000$

TOTAL

$\$ 1,393,000$

\section{$\mathrm{DB} \backslash 360 . S A F$}




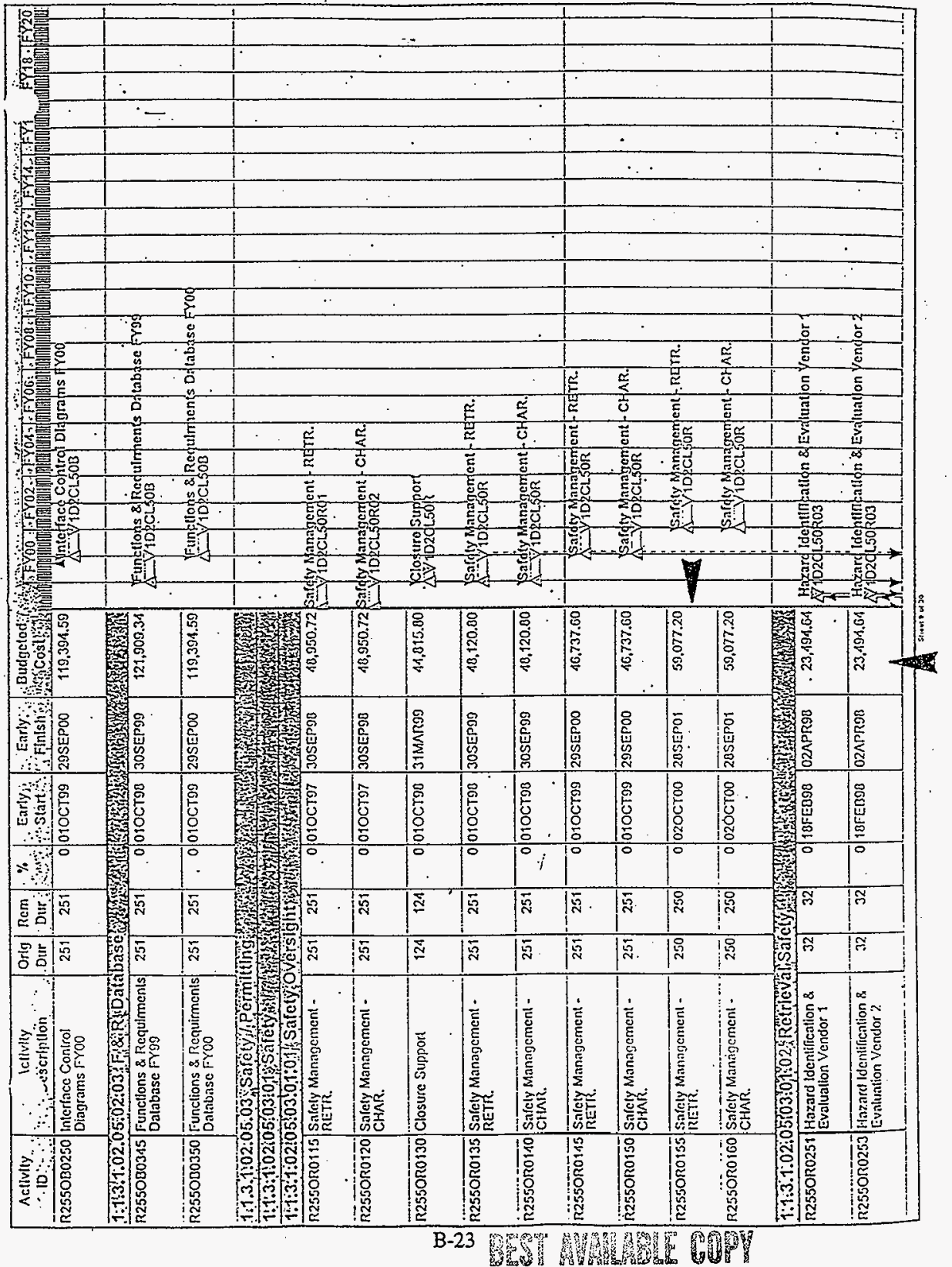




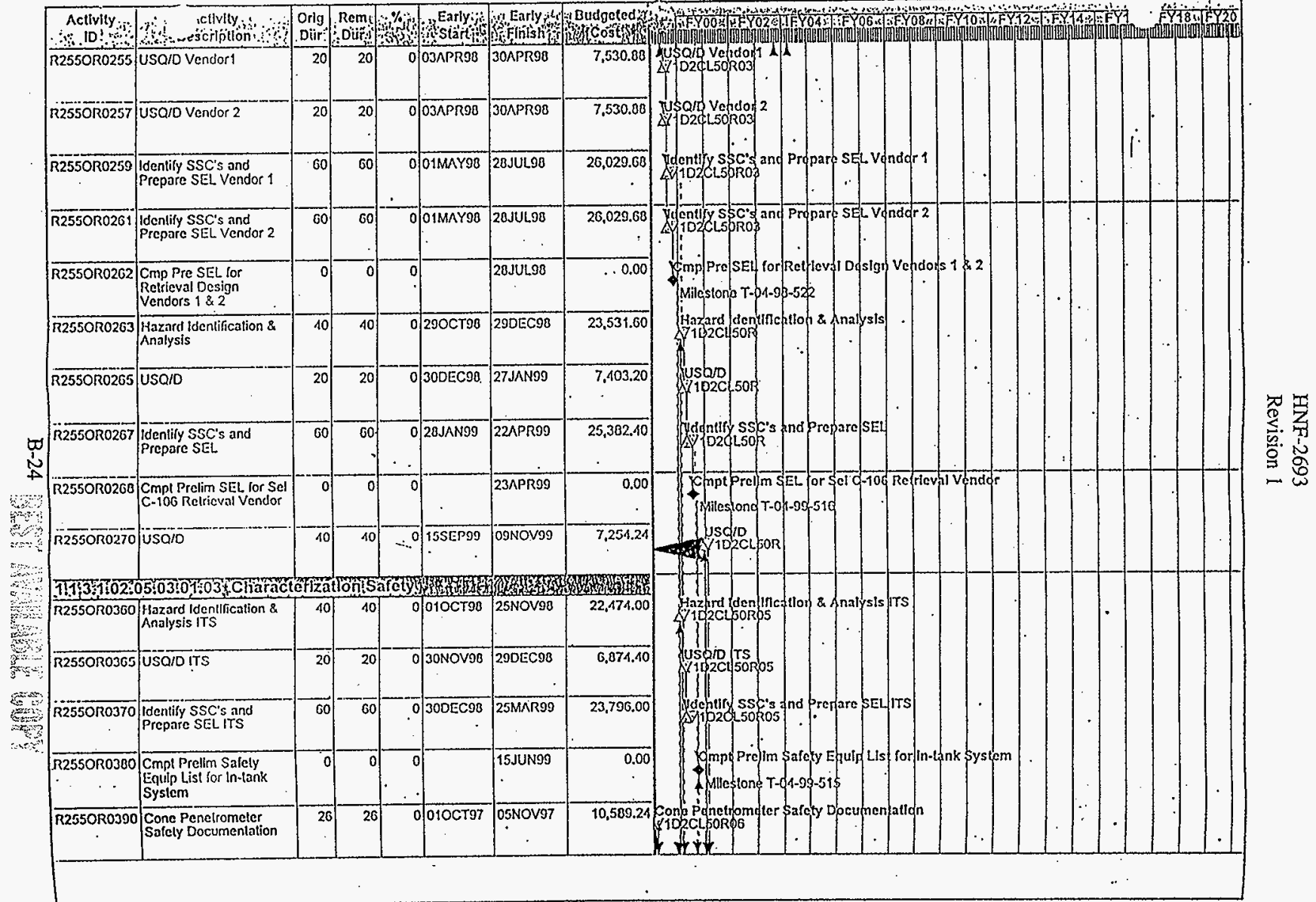

thent it 120 
HNF-2693

Revision 1

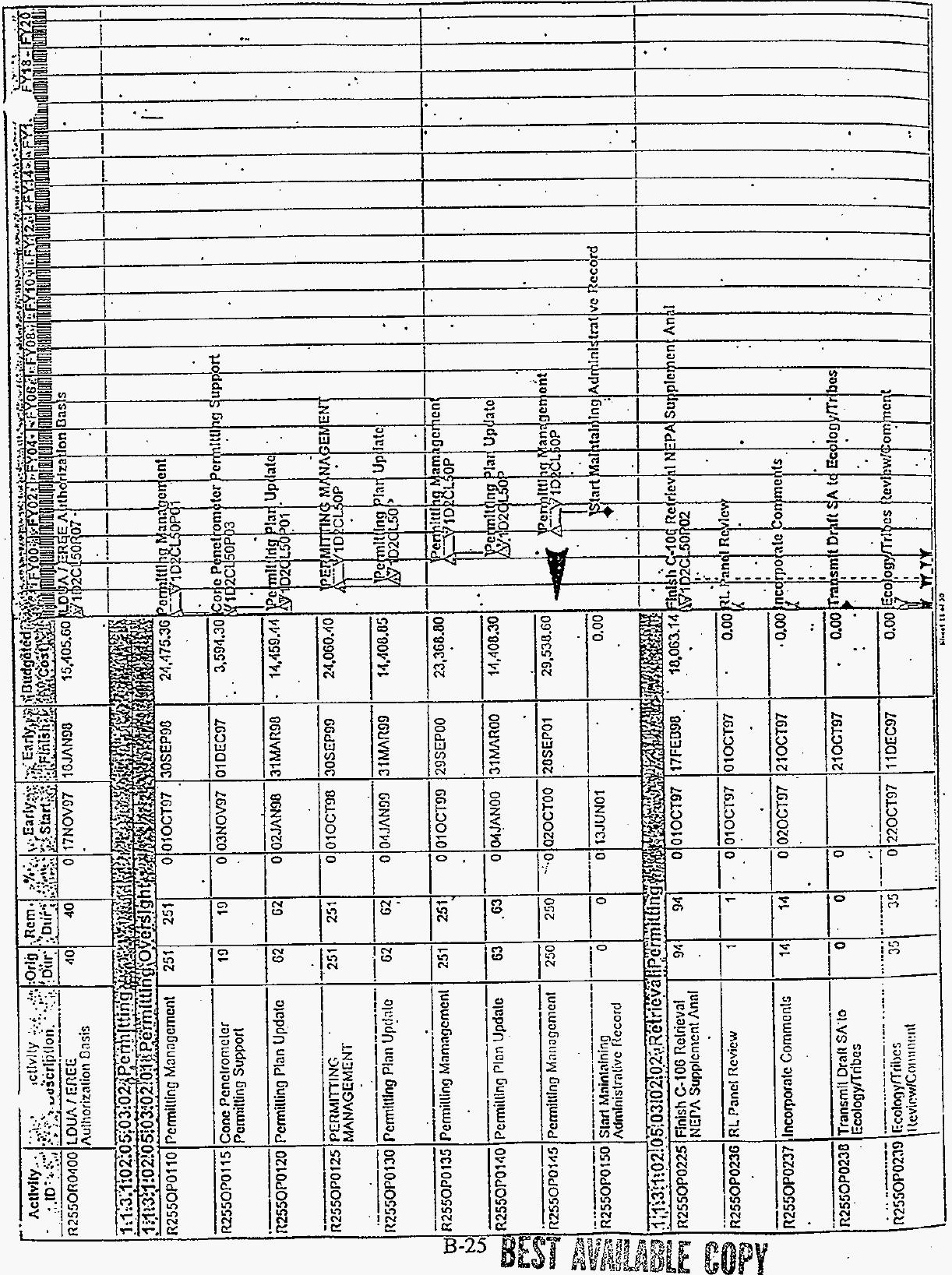


HNF-2693

Revision 1

\section{1. $\quad 10.2 \mathrm{~m}^{3}\left(360 \mathrm{ft}^{3}\right)$ Sluicer Operational Costs}

The estimate for operating the sluicer in tanks 241-AX-101 and 241-AX-103 is based on the data in tables A-1 through A-5. Estimates are based on operating 7 days per week and 24 hours per day.

AX-101 Operational time $\quad 170.2$ days (24.3 wks)

AX-103 Operational time $\quad 57.4$ days (8.2 wks)

5 person crew X 4 shifts $X 40 \mathrm{hrs} / \mathrm{wk}$ X 32.5 weeks X $\$ 95 / \mathrm{hr}$

TOTAL $\$ 2,470,000$

\section{DB $\backslash 360.0 P S$}


HNF-2693

Revision 1

\section{2. $\quad 10.2 \mathrm{~m}^{3}\left(360 \mathrm{ft}^{3}\right)$ Vehicle Operational Costs}

For the $10.2 \mathrm{~m}^{3}\left(360 \mathrm{ft}^{3}\right)$ case, the vehicle is used in all four AX farm tanks. The estimate for vehicle operating time is based on the data in tables A-1 through A-5.

$\begin{array}{lr}\text { AX-101 Operational time } & 19.9 \text { days } \\ \text { AX-102 Operational time } & 21.4 \text { days } \\ \text { AX-103 Operational time } & 19.9 \text { days } \\ \text { AX-104 Operational time } & 6.0 \text { days }\end{array}$

Total $\quad 67.2$ days $(9.6 \mathrm{wks})$

The vendor labor costs are based on a 3 man crew, 4 shifts, and a 4 man home office support for 9.6 weeks of retrieval time at each tank (the labor through the ORR is included with in the installation costs).

There are 4 weeks required to move the system from tank to tank.

There are an additional 4 weeks of time required for the dismantling and removal of the retrieval system.

The total time required is:

Retrieve four tanks

Move system 3 times

Dismantle system

TOTAL
9.6 weeks

12 weeks

4 weeks

25.6 weeks

16 persons @ $\$ 75 / \mathrm{hr}$ X $40 \mathrm{hr} / \mathrm{wk}$ for 25.6 weeks $\$ 1,229,000$

Per diem (12 persons @ $\$ 80 /$ day)

$\$ 172,000$

Sub-total

$\$ 1,401,000$

PHMC labor costs are for a 6 man crew, four shifts, for the 25.6 weeks retrieval and dismantling time.

24 persons @ $\$ 95 / \mathrm{hr}$ for 25.2 weeks

$\$ 2,298,000$

TOTAL

$\$ 3,699,000$

\section{DB\360VEH.OPS}


HNF-2693

Revision 1

This page intentionally left blank. 
HNF-2693

Revision 1

APPENDIX C

\section{COST ESTIMATE DETAILS FOR $1.0 \mathrm{~m}^{3}\left(36 \mathrm{ft}^{3}\right)$ RESIDUAL WASTE LEVEL}


HNF-2693

Revision 1

This page intentionally left blank. 
HNF-2693

Revision 1

APPENDIX C

\section{$1.0 \mathrm{~m}^{3}\left(36 \mathrm{ft}^{3}\right)$ COST DETAILS}

Retrieval to $1.0 \mathrm{~m}^{3}\left(36 \mathrm{ft}^{3}\right)$ Residual Waste--Cost Summary. (2 Sheets)

\begin{tabular}{|l|l|c|}
\hline & \multicolumn{1}{|c|}{ Task Description } & Cost \\
\hline 1 & LLCE removal of tank equipment & $2,818,000$ \\
\hline 2 & $\begin{array}{l}\text { Procurement and installation of sluicing systems and equipment for } \\
\text { tanks 241-AX-101 and 241-AX-103 }\end{array}$ & $22,446,000$ \\
\hline 3 & Design/fabricate/install control room for sluicers & 204,000 \\
\hline 4 & $\begin{array}{l}\text { Purchase and install vehicle retrieval system in } \\
241-\mathrm{AX}-104\end{array}$ & $11,442,000$ \\
\hline 5 & $\begin{array}{l}\text { Design/fabricate/install HVAC system for tanks 241-AX-101, 102, } \\
103, \text { and 104. }\end{array}$ & $1,082,000$ \\
\hline 6 & $\begin{array}{l}\text { Design/install approximately 610 m (2,000 ft) of 10-cm (4-in.) } \\
\text { diameter waste transfer lines between 241-AY-102 and }\end{array}$ & 980,000 \\
\hline 7 & $\begin{array}{l}\text { Design/install new waste transfer jumper pit on west side of AX } \\
\text { farm }\end{array}$ & 334,000 \\
\hline 8 & $\begin{array}{l}\text { Decontaminate and clean out 11 pits in AX and AY farms based on } \\
\text { W-320 experience. }\end{array}$ & $16,500,000$ \\
\hline 9 & PHMC BOP modifications/installations & $5,343,000$ \\
\hline 10 & Safety and Permitting & $1,393,00$ \\
\hline 11 & Sluicing Operational Costs & $2,470,000$ \\
\hline 12 & Vehicle Operational Costs & $10,871,000$ \\
\hline & & $75,883,000$ \\
\hline
\end{tabular}

BOP $=$ Balance of Plant

CCTV $=$ Closed-circuit television

HVAC $=$ Heating, ventilating, and air conditioning

LLCE $=$ Long-length contaminated equipment

PHMC $=$ Project Hanford Management Contractor. 
HNF-2693

Revision 1

Contingency and escalation are assumed to be the same as used by FDNW in the preparation of the Project Design Concepts (May 1997). These are as follows:

Escalation is 5.3 percent for FY 1999 through FY 2006 ( 8 years) for a total escalation of 51.2 percent

32 percent contingency

TOTAL RETRIEVAL COST $75,883,000 \times 1.512 \times 1.32$

$$
=\$ 151,450,000
$$

DB\36-TBL 
HNF-2693

Revision 1

\section{1. $\quad 1.0 \mathrm{~m}^{3}\left(36 \mathrm{ft}^{3}\right)$ Long-Length Contaminated Equipment Removal}

There are 6 pieces of Long-Length Contaminated Equipment (LLCE) that will be removed from the tank pits in AX farm. These will be removed with the existing LLCE system and packaged for burial or disposal as required. damage.

The slurry pump in 241-AY-102 requires removal for replacement, due to radiation

In addition, one of the sluicers in 241-AX-101 and 241-AX-103 will need to be removed to provide access for the vehicle.

The estimated cost for the setup of the LLCE, removal of the item from the waste tank, packaging, and burial/storage is $\$ 418,000$ for the initial item based on Manderbach (1997a). Costs for subsequent items are $\$ 300,000$ each.

\begin{tabular}{|l|r|}
\hline Tank 241-AY-102 slurry pump removal & $\$ 418.000$ \\
\hline Tank 241-AX-101 pit 01A steam coil & $\$ 300,000$ \\
\hline Tank 241-AX-101 pit 01B Sluicer & $\$ 300,000$ \\
\hline Tank 241-AX-102 pit 02A Sluicer & $\$ 300,000$ \\
\hline Tank 241-AX-102 pit 02B Pump & $\$ 300,000$ \\
\hline Tank 241-AX-103 pit 03A Sluicer & $\$ 300,000$ \\
\hline Tank 241-AX-104 pit 04A Sluicer & $\$ 300,000$ \\
\hline Remove 241-AX-101 new sluicer for vehicle access & $\$ 300,000$ \\
\hline Remove 241-AX-103 new sluicer for vehicle access & $\$ 300,000$ \\
\hline \multicolumn{2}{|c|}{ TOTAL (for $1.0 \mathrm{~m}^{3}\left[36 \mathrm{ft}^{3}\right]$ case) } \\
\hline
\end{tabular}

DB\36LLCE 


\section{Revision 1}

\section{2. $\quad 1.0 \mathrm{~m}^{3}\left(36 \mathrm{ft}^{3}\right)$ Sluicing Equipment Fabricate/Installation Costs}

The cost estimate for the design/fabrication and installation of sluicing systems on tanks 241-AX-101 and 241-AX-102 is based on the enhanced sluicing cost estimate for 241-C-106 prepared by FDNW for Job no. E20144 (file no. Z437SAE2) (summary sheet attached). The estimate was modified as detailed below to more accurately reflect the AX farm conditions.

The Total projected cost estimate without escalation or contingency is $\$ 34,140,000$ including site allocations. The following items were removed from the estimate as redundant or not applicable:

\begin{tabular}{|l|r|}
\hline Regulatory compliance & $1,281,000$ \\
\hline Accident analysis & 650,000 \\
\hline Pump pit 241-C-06A & $2,303,000$ \\
\hline Heel pit 241-C-06B & $1,967,000$ \\
\hline Sluice pit 241-C-06C & $1,922,000$ \\
\hline Enc'd pipe pump to heel pit & 298,000 \\
\hline Enc'd pipe heel to sluice pit & 223,000 \\
\hline Heel jet removal & 618,000 \\
\hline Sluicer removal & 594,000 \\
\hline Vendor perform retrieval & $2,000,000$ \\
\hline Vendor Demobilization & 500,000 \\
\hline Ready tank for closure & $2,500,000$ \\
\hline \multicolumn{1}{|c|}{ SUB-TOTAL } & $14,856,000$ \\
\hline
\end{tabular}

The following items were added to the estimate to account for operation in two tanks:

\begin{tabular}{|l|r|}
\hline Vendor equipment & $2,000,000$ \\
\hline Vendor equipment installation & $1,162,000$ \\
\hline SUB-TOTAL & $3,162,000$ \\
\hline
\end{tabular}

\section{$\mathrm{DB} \backslash 36 . \mathrm{SLU}$}

TOTAL $(34,140,000+3,162,000-14,856,000)=\$ 22,446,000$ 
YLUOR DAHIEL HORTHWEST, IHC. NUMATEC HAHFORD CORPORATION JOB HO. EZO144 JOI HO. E20141
- IEST - XuTERACTIVE ESTTMATIHG * concept - EnItance sturcino ORDER OF MAGNITUDE

PHMCROL PROJECT COST SUMMARY
PAGE 1 OF 20

DATE 01/07/97 17:51:36

DY TLH, JJM, BHO, CDL

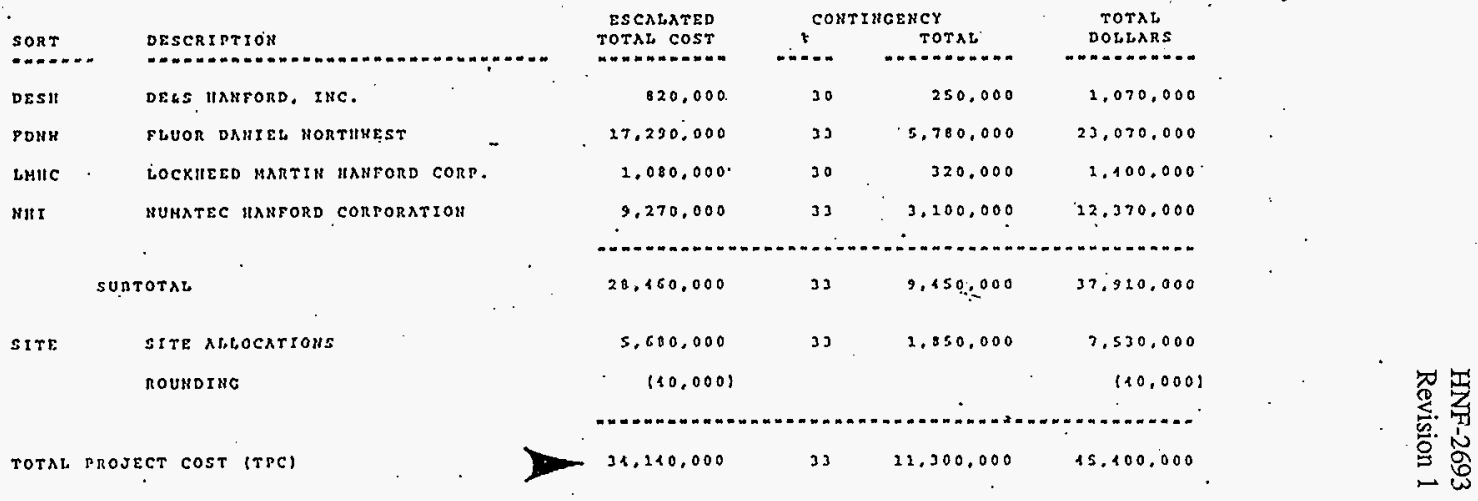

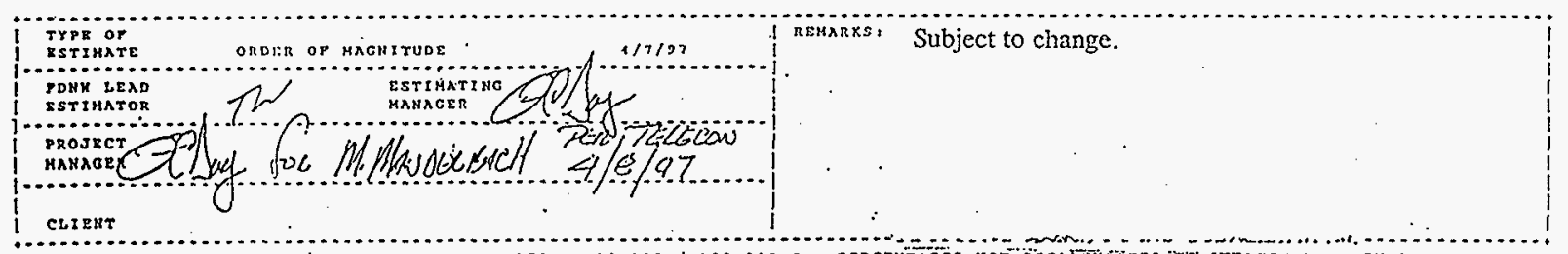

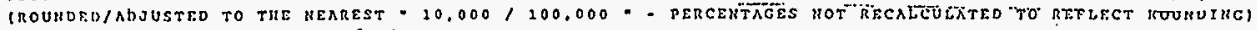


HNF-2693

Revision 1

\section{3. $\quad 1.0 \mathrm{~m}^{3}\left(36 \mathrm{ft}^{3}\right)$ Sluicer Control Room}

The estimated cost for the control room/lunch room is taken from the $1994 \mathrm{~W}-320$ estimate (Job no. W-320/ER4319 page 23 attached). One control room for the systems used in tanks $241-\mathrm{AX}-101$ and $241-\mathrm{AX}-103$ is adequate. This control room would be located outside the tank farm boundaries.

The W-320 control room was not installed (a mobile office was modified) so the costs for the control room are not included in the later estimates.

From page 23 of the estimate (rounded) $\$ 204,000$

$\mathrm{DB} \backslash 36 . \mathrm{CNT}$ 
KAISER EHGINEERS IIAHFORD WESTIHGHOUSE HAHFORO COHPAIU JOQ NO. H-320/ERG319

\section{$\cos \pi$}

CODE/HOS

3490. AY TOUIPHEHT

$3510^{\circ}$ WYORAULIC TARILER/SIROLGOACK

3580 CEIIRTIC FABRICATIOI

6212 CIITRL RH IIISTR. IHSTALLATIOH

4221 TRAHSFER LIHE

4222

6223

4314

6315

4322

4322

4324

4341

4343

4351
4352

( 4353

356

Fin 357

202411

3413

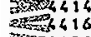

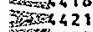

$20 x+422$

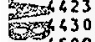

04508

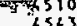

$\$ 604$

4605

$\operatorname{tin}_{4} 610$.

3,700
4777

COHTROL RH/LUHCH RH

CORE DRILLS

SUPERS PIPING THSTALLATIO

C. FARH IIISIRUAEHT AIR \& VEUI

C-IARH ELECTRICAL

HASF HOCK.UB

SLUICIIIG EOUIP.

CHILLER SXID

POCESS SKIO

EXIIAUST SYSTEH

EOG SUPRESSTOH SYS

EXISTIIIG AIR IILET HOD'S

isc BADS

HISC. THSTRUMEUTATIOU

PIT SLEEVE / CHOEDS

JUHPERS

Exchystion. tibing

EICASED PISING IIISTALLATIOH

DACXEILL PIPIILE

AY-FARU ELECTRICAL

SLUICIHG FOUIP, PROCUREHEH

SLUICIHG EOUIPHEMT C. 106

COLD TESTIHC

FABRICATIOH/IUSTALLATIOH

CEHERAL COUSYRUCTIOH SUPPORT - ERS

COITATUER TRAILER FAB CTC

GEHERAL COHSTRUCTIOH SUPPORT-SLUICE

GEHERAL \& TECHI. SERVICES-SLUICIIIG
* TEST - IUTERACIIVE ESTIHATILE * * TAllK $241-6-106$ SLUICING REVISIOH \#1 DOE_RO4 . COST CODE ACCOUHT SUHAARY ESTIHATE
SUDTOTAL

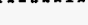

ONSITE

7060

493220

660184

1259047

259047
6403

204417.

499006
102622

372617

254401

39131
869740

247311

512504

40410

237120

54897

13304

10925

134525

35169
240235

731

0458

48398

6695

057090

017615

2501207

1505123

936509

49590

304220

580500

10703677

TOYAL

\begin{tabular}{|c|c|c|}
\hline \multirow{2}{*}{\multicolumn{3}{|c|}{7060}} \\
\hline & & \\
\hline & 0 & 660184 \\
\hline & 0 & 713564 \\
\hline 2718 & & $1530 B 93$ \\
\hline 13 & & 7709 \\
\hline 4,17 & & 246110 \\
\hline & 0 & 489006 \\
\hline & 0 & 102622 \\
\hline & 0 & 372617. \\
\hline & 0 & 254481 \\
\hline & 0 & $3013 i$ \\
\hline & 0 & 069740 \\
\hline & 0 & 247311 \\
\hline & 0 & 512504 \\
\hline . & 0 & 40410 \\
\hline & 0 & 237920 \\
\hline & 0 & 4549 \\
\hline & 0 & 540.97 \\
\hline & 0 & 13300 \\
\hline & 0 & 7917 \\
\hline & 0 & 210925 \\
\hline - & 0 & 134525 \\
\hline & 0 & 35161 \\
\hline & $\begin{array}{l}0 \\
0\end{array}$ & $\begin{array}{r}210235 \\
711\end{array}$ \\
\hline & 0 & 0459 \\
\hline & 0 & 40398 \\
\hline & 0 & 2339 \\
\hline & 0 & 366957 \\
\hline & 0 & 857899 \\
\hline & 0 & 1017615 \\
\hline & 0 & 2581207 \\
\hline & 0 & 1505123 \\
\hline . & 0 & 3307096 \\
\hline & $\begin{array}{l}0 \\
0\end{array}$ & $\begin{array}{r}938509 \\
48598\end{array}$ \\
\hline & 0 & 304.220 \\
\hline & 0 & 539500 \\
\hline
\end{tabular}

311,053

20090530
ONSITE
IHDIRECTS TUB TOYAL ESCALATION

Trotsi

sub TOIAL \% TOTAL 0.00

.0 .00

1.60

1.61

1.60

3.61

3.61

3.61

3.01

3.01

3.61

3.61

3.61

3.61

3.61

3.61

3.61

3.09

3.09

3.09

3.09

3.94

3.09
3.09

3.08

3.09

2.46
2.46

2. 1.6

0.12

0.14

2.17
0.00

2.17

2.17

0

7060

493220

460184

11417

24495

72400

1555387

250056

517049

3938

18043

13451

106326

197.263680

1412

31397

0928

10501

3560 .

164
1981

1981
481

285

3516

5233

0657

20
329

1033

14274

21104

25033

63190
1749

4597
20322

263680
40543

901137

256239

531005

41077

245600
-4713

56078

13780

0203

22744

36529

257002

5700

2430

231

042640

1042640

2644705

3312693

956031

49598

602303

1.77 356343

201,54072
COMTIUGEHCY $\ldots$ TOTAL

PREE 23 OF 32

GY GOC/JPH/DXU/CDL/XDE

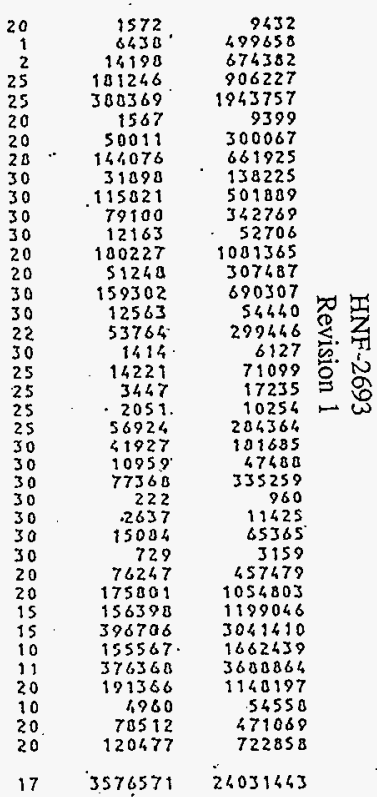


HNF-2693

Revision 1

\section{4. $\quad 1.0 \mathrm{~m}^{3}\left(36 \mathrm{ft}^{3}\right)$ Vehicle Retrieval System costs}

\section{Vendor Costs}

The vendor cost estimate is based on the two vendor systems currently being designed for the retrieval of the heel in tank 241-C-106. This also assumes that the same type of service contract will be used to procure the retrieval systems for the AX farm as is being used for the procurement of the 241-C-106 vehicle retrieval system.

\section{Vendor supplied system/equipment}

Design, fabrication, testing, and delivery of a vehicle based retrieval system ready to install in the AX farm (based on discussions with HTI 241-C-106 Heel Retrieval System Engineers).

$$
\$ 5,500,000
$$

\section{Pre-operational work at $\mathrm{AX}$ farm}

ORR, training, and acceptance testing based on 6 month duration. Three person vendor crew, four shifts, and four person home office support on one shift.

$$
\text { Labor (16 persons @ \$75/hr for } 24 \text { weeks) } \quad \$ 1,152,000
$$

Per diem (16 persons @ \$80/day for 24 weeks) $\$ 30,700$

Warehouse and office rental in the Tri-Cities area.

Eighteen month duration based on the use of one vehicle that is moved tank to tank

$\$ 90,000$

Sub-total

$\$ 6,772,000$

\section{PHMC Bid and Award}

Based on HTI 241-C-106 Heel Retrieval System costs

$\$ 200,000$

PHMC Contract Management

Based on HTI 241-C-106 Heel Retrieval System costs

$\$ 400,000$ 
HNF-2693

Revision 1

PHMC ORR/ATP

Based on HTI 241-C-106 Heel Retrieval System costs

$\$ 400,000$

Three additional ATP/OTPs after vehicle moved

$\$ 300,000$

Sub-total

$\$ 1,300,000$

\section{Installation Costs}

The estimated cost to install a vehicle based retrieval system in 241-AX-101, 102, 103, and 104 is assumed to be the same as for tank 241-C-106. The installation costs in 241-C-106 is from sheet 17 (attached) of the baseline estimate. This does not include the costs to modify the farm/tank for acceptance of the vehicle system.

Four at

Sub-total

TOTAL
$\$ 842,500$ each

$\$ 3,370,000$

$\$ 11,442,000$

DB\36.VEH 
HNF-2693

Revision 1

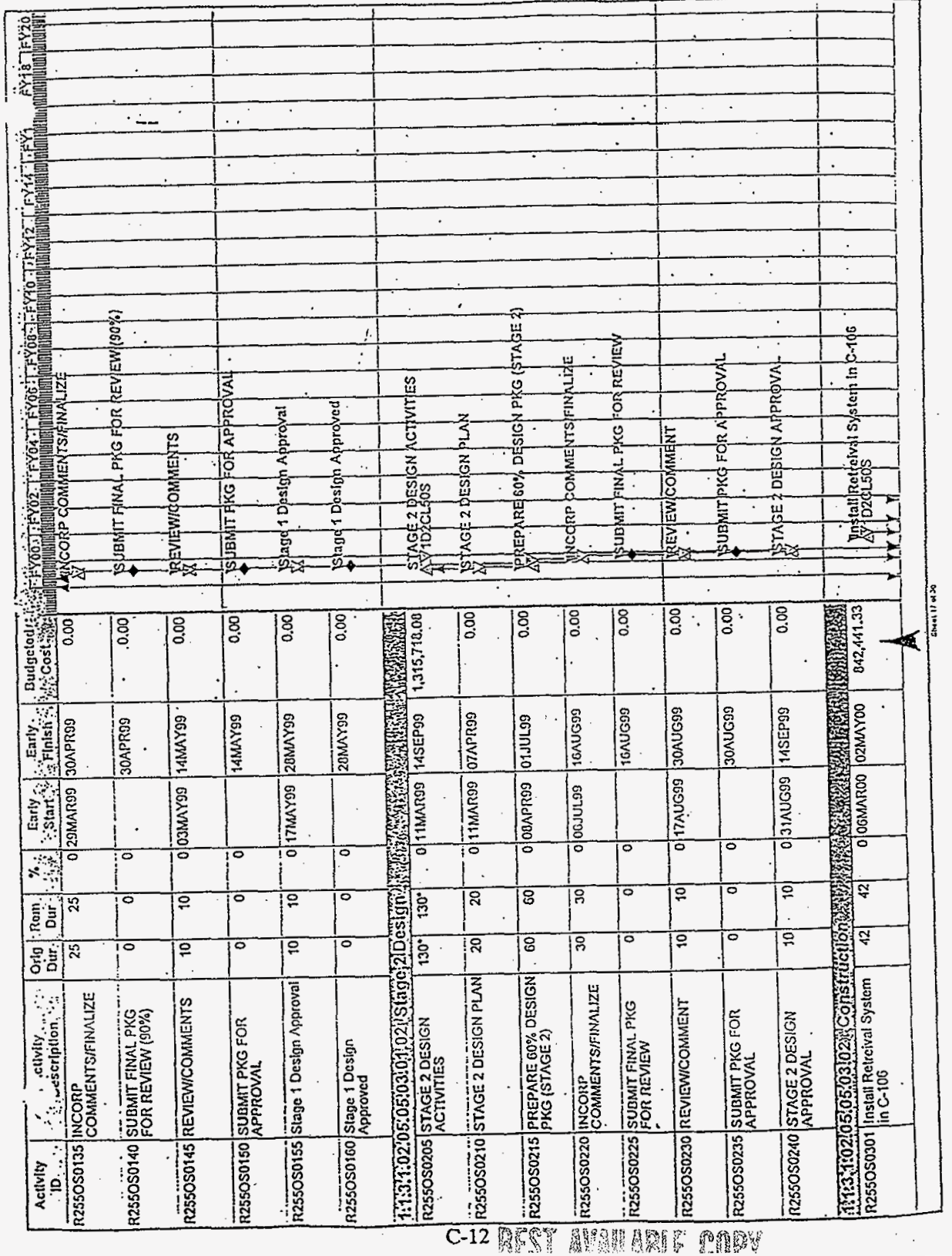


HNF-2693

Revision 1

\section{5. $\quad 1.0 \mathrm{~m}^{3}\left(36 \mathrm{ft}^{3}\right)$ HVAC System Design/Installation Costs}

The estimate for a new AX farm HVAC system is based on the FDNW W-320 HVAC skid estimate contained in file no. W320PDA4, job no. W-320/P7448M (page 14 attached). This is the same as for the $162 \mathrm{~m}^{3}\left(3,600 \mathrm{ft}^{3}\right)$ case with an additional $\$ 100,000$ to connect the system to 241-AX-104.

AX Farm HVAC System for three tanks

Additional cost to connect to 241-AX-104

TOTAL
$\$ 982,000$

$\$ 100,000$

$\$ 1,082,000$

DB\36HVAC 
XAISER EIIGTNEERS MAMTORD HESTIMGHOUSE HAMPORO COMPAHY sos NO. $4-320 / 87438$

PILE NO. H32ORDA4

YAS DESCRIPTIOU

1509AD process duILDIUG crocurnuENT

ISOMAD PROCESS DUILDING OROCUREMENG
ISOSAC CHILAER SXID PROCUREMEHT

SUBTOTAL 4509 IVAC SKID RROCUREMETT

4520AB pURCHASE ruMr

ISIOAC ETECTRICAE ROUITMENT PROCUREMENT

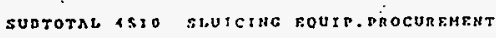

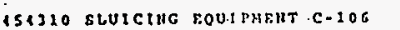

' suatotal $1583^{\circ}$ sutcing foutrmsut c-206

$?$

SUatotal is EXPENSE PROCUREMENT

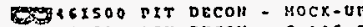

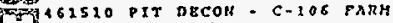
00162520 PIT DEcion. AY-102 FARH

suntotA 1615 rtT nRcon

SUBTOTAL 16 PIT DECON

170000 construct ton sERvtCEs - cto

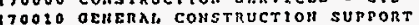

SUBTOTAL 4700 COHSTRUCTIOH STRUTCES.

TTEF) $47790 \cdot$ EOUTPHENT USACE

$9177720 \mathrm{CF}$ SUPFORT

$\$ 177720$ OUALTTY SUPROR

- SURtotal 4777 GEHERAL TECIT. SERVICES

SUBTOTAL 47 CONSTRUCTIOH SERVICPS

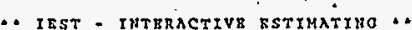

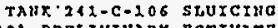

,OF PRELTHIMARY ESTIKATB

DOE ROZ - KORK IREAXDOH STRUCTURE SUMMARY
PAGE. 11 of 35

DATE $07 / 25 / 3515121106$

BY KE/DH/JK/LR/CL/RO/KR

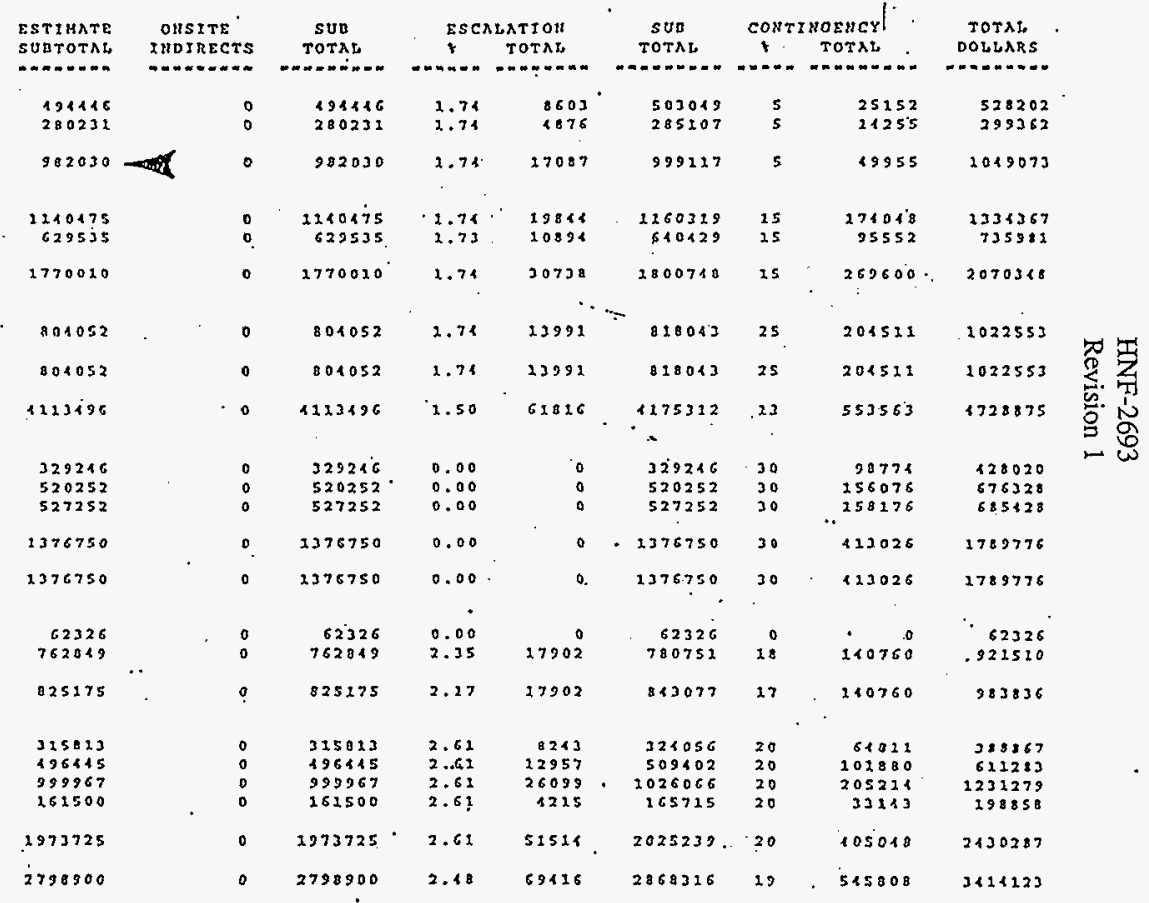


HNF-2693

Revision 1

\section{6. $\quad 1.0 \mathrm{~m}^{3}\left(36 \mathrm{ft}^{3}\right)$ Waste Transfer Line}

\begin{tabular}{|c|c|}
\hline Description & Length \\
\hline \multicolumn{2}{|l|}{ 241-AY-102 } \\
\hline Pit $02 \mathrm{~A}$ to new valve pit & $76 \mathrm{~m}(250 \mathrm{ft})$ \\
\hline Pit $02 E$ to new valve pit & $72 \mathrm{~m}(235 \mathrm{ft})$ \\
\hline \multicolumn{2}{|l|}{ 241-AX-101 } \\
\hline Pit 01A to new valve pit & $67 \mathrm{~m}(220 \mathrm{ft})$ \\
\hline Pit $01 B$ to new valve pit & $61 \mathrm{~m}(200 \mathrm{ft})$ \\
\hline Pit 01D to new valve pit & $56 \mathrm{~m}(185 \mathrm{ft})$ \\
\hline \multicolumn{2}{|l|}{ 241-AX-102 } \\
\hline Pit $02 A$ to new valve pit & $58 \mathrm{~m}(190 \mathrm{ft})$ \\
\hline Pit $02 B$ to new valve pit & $50 \mathrm{~m}(165 \mathrm{ft})$ \\
\hline \multicolumn{2}{|l|}{ 241-AX-103 } \\
\hline Pit $03 \mathrm{~A}$ to new valve pit & $38 \mathrm{~m}(125 \mathrm{ft})$ \\
\hline Pit $03 C$ to new valve pit & $41 \mathrm{~m}(135 \mathrm{ft})$ \\
\hline Pit $03 \mathrm{D}$ to new valve pit & $29 \mathrm{~m}(95 \mathrm{ft})$ \\
\hline \multicolumn{2}{|l|}{ 241-AX-104 } \\
\hline Pit 04A to new valve pit & $28 \mathrm{~m}(90 \mathrm{ft})$ \\
\hline Pit 04D to new valve pit & $22(70 \mathrm{ft})$ \\
\hline TOTAL LINE LENGTHS & $598 \mathrm{~m}(1,960 \mathrm{ft})$ \\
\hline $\operatorname{cosT}$ & $\$ 980,000$ \\
\hline
\end{tabular}

Note 1: Fabrication and installation cost for the waste transfer line is $\$ 3,279 / \mathrm{m}(\$ 1,000 / \mathrm{ft})$ for a double line.

Note 2: Each pit above requires core drill and nozzle installation i.e. 12 each for the $1.0 \mathrm{~m}\left(36 \mathrm{ft}^{3}\right)$ case. 
HNF-2693

Revision 1

\section{7. $1.0 \mathrm{~m}^{3}\left(36 \mathrm{ft}^{3}\right)$ Pit Design/Installation Costs}

The estimate for a new AX farm above grade transfer line (jumper) pit is based on the pit cover block fabrication and caisson/slab support for the manipulator arm costs contained in the Cost Normalization Unit Estimates (Manderbach 1997a). Assume same cover block costs and that the pit will cost the same as the manipulator slab.

Cover block $\$ 102,000$

Pit

$\$ 232,000$

TOTAL

$\$ 334,000$

DB\36.PIT 
HNF-2693

Revision 1

\title{
8. $1.0 \mathrm{~m}^{3}\left(36 \mathrm{ft}^{3}\right)$ Pit Decontamination Costs
}

For the $1.0 \mathrm{~m}^{3}\left(36 \mathrm{ft}^{3}\right)$ case, 10 pits in $\mathrm{AX}$ farm and the pump pit at 241-AY-102 are used for the retrieval activities.

Discussed the condition and radiation levels in the pits with Dave Bragg in a Telecon $4 / 20 / 98$ as summarized below.

Dave is not aware on any record of the activities that have been carried out in the last 15 years in the pits. Dave indicated that the pits probably haven't been opened in the last 15-20 years. Dave has no information on the pits as compared to the 241-C-106 pits that were decontaminated for Project W-320. Dave stated that John W. Bailey might have some recollection of the AX farm retrieval sluicing activities and that he would be a good source to try. John Bailey indicated that the pits in AX Farm should be in better condition than those in C Farm (the drains should work).

For the purposed of preparing this estimate, will assume that the pits are in comparable condition to the 241-C-106 pits. From the FDNW estimate for the Vehicle Based Retrieval System, Job no. E20144 (file ZA37SAF2), the allocated cost for decontamination of the pits is $\$ 1,500,000$ each (page 7, item $7 \mathrm{E}-4$ attached).

TOTAL

(11 pits) $\$ 16,500,000$

\author{
$\mathrm{DB} \backslash 36 . \mathrm{DCN}$
}


FLUOR DAUIEL NORTHEST, ZHC. NUUATEC HANFORD CORPORATION JOB NO. E20141

FILE NO. Z437SAP2
- IEST - IUTERACTIVE ESTIMRTING - CONCEPT 2 - VEITICEE DASTE HASTE RETRIEYSE $S$ T D Y - RO $M$

PHACROJ * ESTIMATE DASIS SHEET.
PAG 7 OF 16

OATE 01/15/97 07:12:17

DY TLH, JJM, Rूo, COL

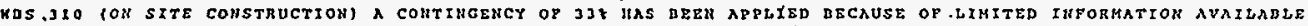
ON TIE RADIATION LEVELS THAT KILL DE EHCOUNTERED DURINO PIPE INSTALLATIOH, PIT MODIFICATIONS AHD DECOH-

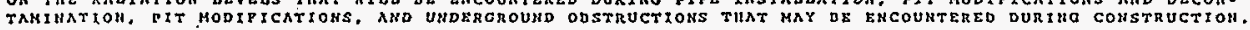
TARE

IHPUT.

\section{ROUNDERG}

THE PROJECT COST SUMHARY RETORT IS SUMHARIZED AND ADJUSTED/ROUHDED AS FOLLOHS

THE ESCALATED TOTAL COST COLUMN, CONTHGEHCY TOTAL COLUMN AHD TOTAL DOLLARS COLUMH SUD-TOTALS ARE SUMHARTZED BY COHTRACTOR, THE COLUHA SUDTOTALS ARE ADJUSTED/ROUNDED TO TIE HEAREST \$2.0OO/\$20.000. THE PROJECT TOTAL SUMMARY LIHE. TOTALS ARE

ADJUSTED/ROUHDED TO TIE MEAREST $\$ 20,000 / \$ 100,000$

7. REMARXS

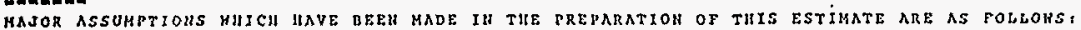

A.) THE TEMPORARY CIAHGE ROOH TRATLER, MOBTLE DRYLL RIO AHD ASSOCTATED EQUTPMENT, VACUUM TRUCK (GUZZLER), AMD CRAHES . HILL IE FURUISHED TO THE PROJECT $A T$ NO COST EXCEPT YOR THE SET UP COSTS.

D.) BURHOUT COSTS ARE HOT IMCLUDED IH THIS COST ESTIMATE DY DIRECTION OP PHAC. IP DURHOUT IS

AODED ITS COST IS APRROXIMATELY \$2.5M AMD IS DASED UPOH AN ASSUMED 1OME READIUG AT THE UPPER SECTION, OP

THE CASIHG AHD $25 \mathrm{mr}$ AT THE LOHER SECTIOH OP THE CASING, (REP. C. C. MAIL). OTHER CONSTRUCTIOH HORK. INSIDE.

THE FARH FRHCE, HAS ESTIKATED AS $10 \mathrm{~m} X$. RAD LEVELS ADOVE $25 \mathrm{mI}$ IS NOT, ABTICIBATED.

C.) ALL CONTAMXUATED SOIL HAS ASSUHED TO BE LOR RAD AND YAS ESTTMATED AS BACXFILE OHLY IDURIAL TH BARRELS HOT INCL.

D.) THE TOTAL HUMDER OF DRAHINGS, DY OISCIPLIHE, AHD AH ALLOHAHCE OF 150 MAM WOURS EQCH HAS SROVIDED DY ENGIHEERIMG.

E.J ITEHS THAT ARE NOT THCLUDED IN THIS COST ESTRHATE:

1. FLAKHAULE GAS. TT IS ASSUKED TILTT THIS HAS COVERED IH THE K-320 PROJECT.

2. CONTROL MOOH. THE COUTROL ROOM PROVIDED TH H-32O KILL DE USED.

3. APTER OSERATYOHS IS COMPLETE. THE EOUTPMENT HILE DE ABANDONED IN. JLACE (EXCEPT ENILAMCED SLUICERI.

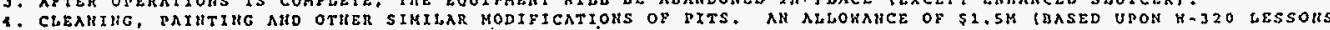
LEARHED PER PIT FOR DECOKTAMIMATION IS IUCLUDED.

5. THE HVAC SYSTEM THAT W-320 IUSTALLED IS HOT MOOKFIED AMD XS HOT IHCHUDED IM THIS COST ESTIMATE.

6. SPARE PARTS.

7. AODITXOHAT RBMOTE CAMERAS AS THIS HAS THSTALLE BX H-320.

F.I PIRIUG ALHOHAHCES ARE YOR HORMAL PIPIUG AHD ARE HOT ASME, SECTIOU 3 (H-ETAMPED).

C.) H-J2O REPLACEMEHT ITEHS ROR FAILED FQUTPMEHT ARE AH EHOTHEERYHG ALLOHARCE OF

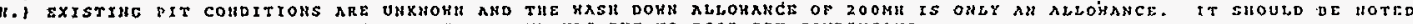

TIIAT PROJECT H-320 EXPERIEHCED HIGUER MAMHOURS DUE TO POOR FIT CONDITIOUS.

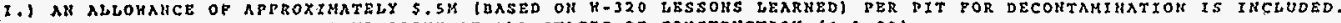

J.I ESCALATIOH IS OASED OH A MIDPOIHT OF ALL STAGES OP CONSTRUCTROH $(A-1-93)$. 
HNF-2693

Revision 1

\section{9. $\quad 1.0 \mathrm{~m}^{3}\left(36 \mathrm{ft}^{3}\right)$ BOP Mods/Installation}

The unit costs used in this section were taken from the FDNW. Cost Normalization Unit Estimates (Manderbach 1997a).

\section{Waste Transfer Line Jumpers}

Eight jumpers will be required in the new transfer pit to route the eight lines coming from the 4 tanks (241-AX-101, 241-AX-102, 241-AX-103, and 241-AX-104).

Ten jumpers will be required for the pits in AX farm and two required at 241-AY-102.

TOTAL JUMPERS REQUIRED $20 @ \$ 56,000$ ea

$$
\text { TOTAL COST } \$ 1,120,000
$$

\section{Cover Block Removal}

Remove the cover blocks from the ten pits in AX farm (3 each on 241-AX-101 and 241-AX-103; 2 each on 241-AX-102 and 241-AX-104)

Remove/replace the cover blocks from the pump pit on 241-AY-102 for replacement of the pump due to radiation damage and the sluice pit for core drilling.

TOTAL COVER BLOCKS REMOVED $12 @ \$ 77,300$ ea

TOTAL COST $\$ 928,000$

\section{Cover Block Fabrication}

Fabricate and install new cover blocks for the ten pits in $\mathrm{AX}$ farm ( 3 each on 241-AX-101, 241-AX-103, and 2 each on 241-AX-102, 241-AX-104).

TOTAL COVER BLOCKS FABRICATED $10 @ \$ 102,500$ ea

$$
\text { TOTAL COST } \$ 1,025,000
$$

\section{Cover Block Disposal}

Dispose of the ten cover blocks removed from the pits in $\mathrm{AX}$ farm.

TOTAL COVER BLOCKS DISPOSED

TOTAL COST
$10 @ \$ 54,800$ ea

$\$ 548,000$ 
HNF-2693

Revision 1

\section{Greenhouse Setup/Teardown}

Setup and teardown of greenhouses and shield walls on the ten pits in $A X$ farm and two pits at 241-AY-102.

TOTAL GREENHOUSE SETUP/TEARDOWN $12 @ \$ 79,400$ ea

$$
\text { TOTAL COST } \$ 953,000
$$

\section{Pit Core Drill}

Core drill the 10 pits in $\mathrm{AX}$ farm and two pits at 241-AY-102 for the waste transfer lines.

TOTAL CORE DRILLS $\quad 12 @ \$ 29,200$ ea

$$
\text { TOTAL COST } \$ 350,000
$$

\section{Concrete Pads}

Install concrete mounting pads at the $4 \mathrm{AX}$ farm tanks. Assume $9.3 \mathrm{~m}^{2}\left(100 \mathrm{ft}^{2}\right)$ total at each tank.

TOTAL CONCRETE PADS $\quad 37.2 \mathrm{~m}^{2} @ \$ 850 / \mathrm{m}^{2}\left(400 \mathrm{ft}^{2} @ \$ 79 \mathrm{ft}^{2}\right)$

$$
\text { TOTAL COST } \$ 32,000
$$

\section{CCTV Installation/Removal}

Install CCTV units in the four AX farm tanks.

$\begin{array}{cc}\text { TOTAL CCTV INSTALLATIONS } & 4 @ \$ 52,000 \text { ea } \\ \text { TOTAL COST } & \$ 208,000\end{array}$




\section{1-AY-102 Pump Replacement}

Replace the supernate pump in 241-AY-102 (due to radiation damage). The cover block removal, pump removal, and greenhouse setup/teardown are covered in the previous items. Assume pump disposal cost are comparable to cover block disposal costs from Manderbach (1997a).

241-AY-102 PUMP INSTALLATION

241-AY-102 PUMP DISPOSAL

TOTAL COST
1 each @ $\$ 125,000$

1 each@ $\$ 54,800$

$\$ 179,000$

TOTAL PHMC BOP MODIFICATIONS/INSTALLATIONS $\$ 5,343,000$

136BOP 
H̀NF-2693

Revision 1

\section{0. $\quad 1.0 \mathrm{~m}^{3}\left(36 \mathrm{ft}^{3}\right)$ Safety and Permitting Costs}

The estimates for the safety and permitting costs are based on the HTI heel retrieval baseline estimate (pages $9,10,11$ attached). The AX farm retrieval safety efforts are considered to be approximately double those of the baseline estimate. Additionally, $\$ 750,000$ is included for BIO amendment activities. The estimate is also based on a 3-year project duration.

Safety

Management (assuming 3-year duration)

180,000

USQ

15,000

HI\&E

48,000

Safety Equipment Lists

52,000

BIO amendment

750,000

Sub-total

$\$ 1,045,000$

\section{Permitting}

Management

90,000

NEPA supplement analysis

N/A

Air Permits (NOC) \$43k ea tank

129,000

Air Permits (NOC) for the pits at each tank (\$43k ea)

129,000

Sub-total

$\$ 348,000$

TOTAL

$\$ 1,393,000$

DB\36.SAF 
HNF-2693

Revision 1

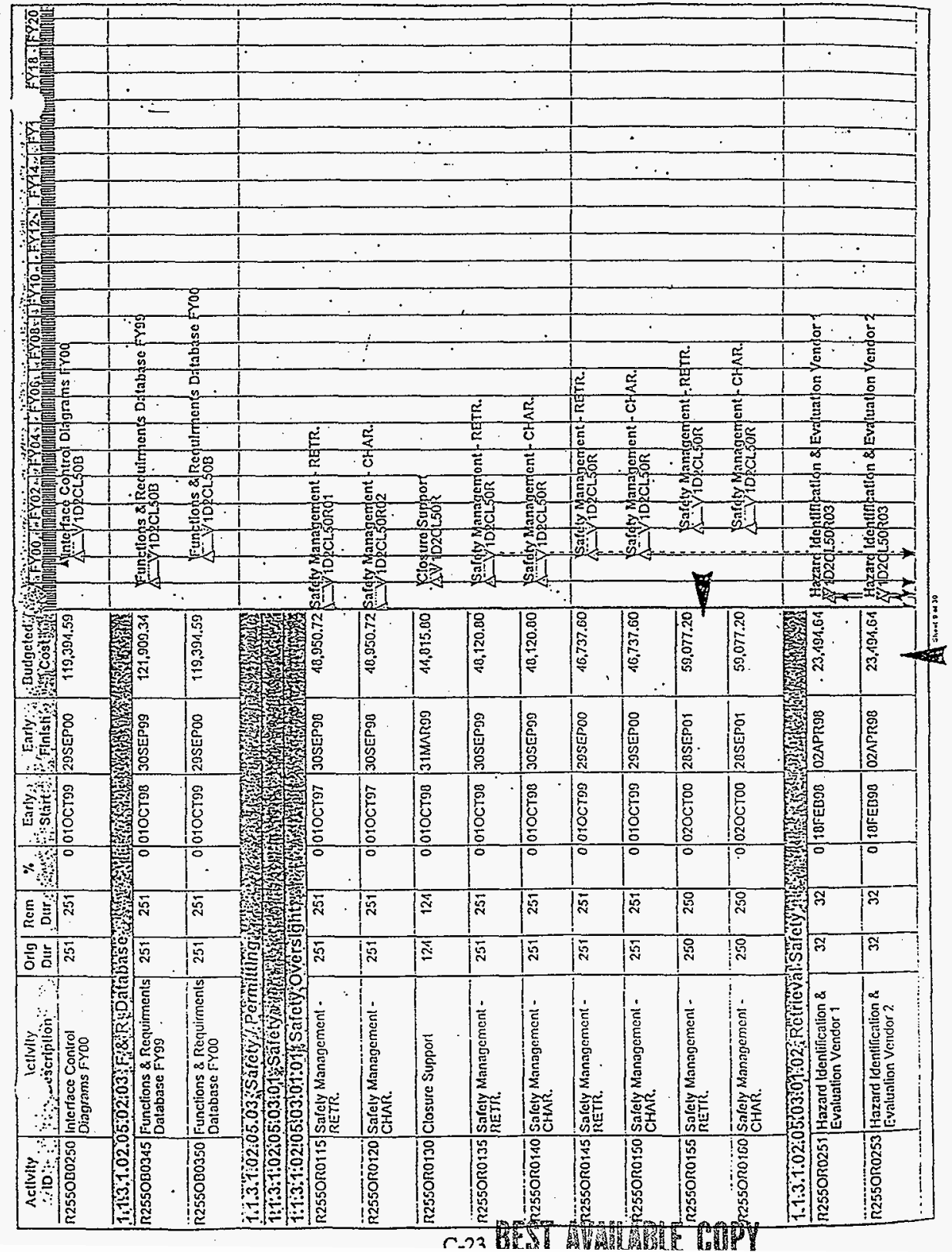


HNF-2693

Revision 1

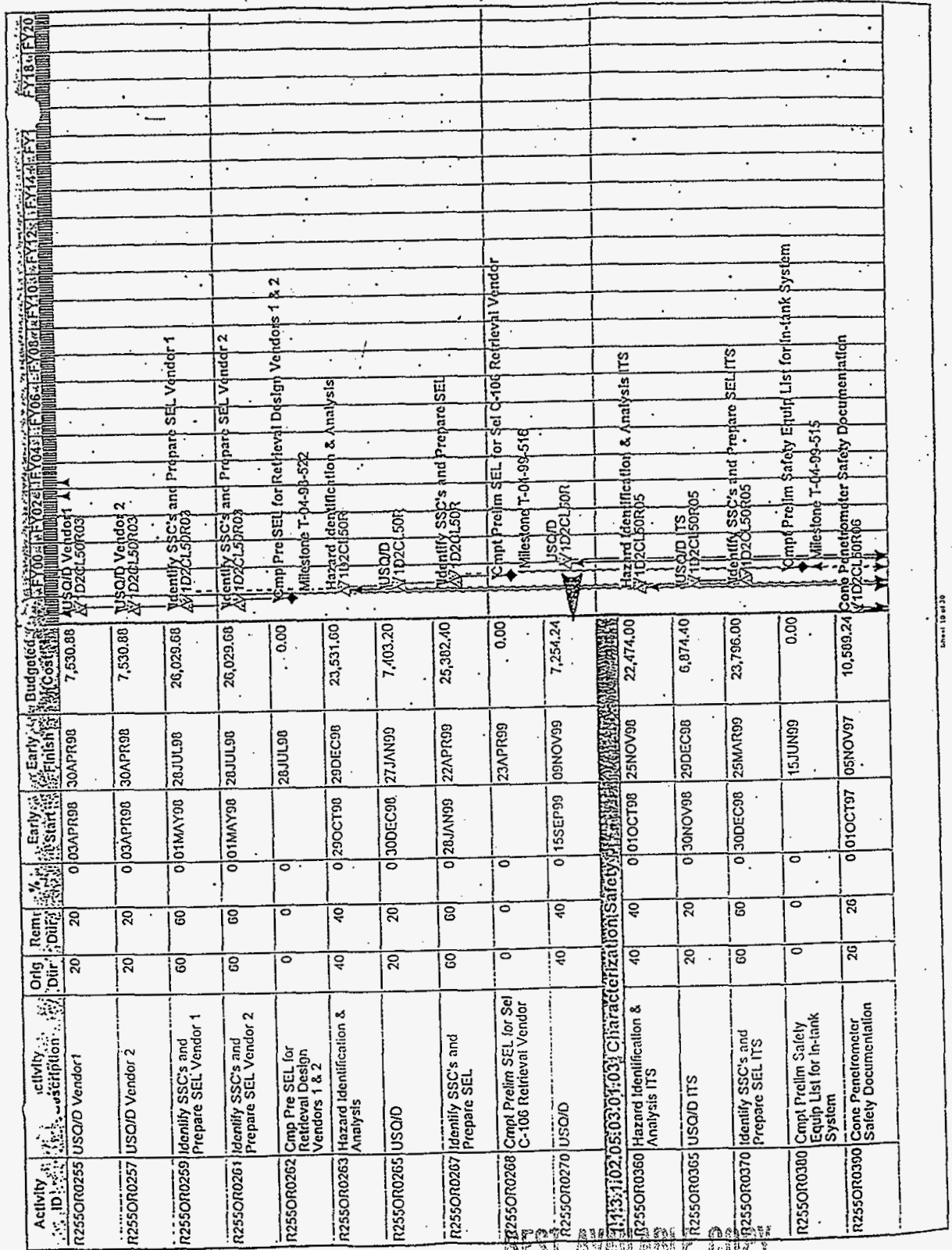

$\mathrm{C}-24 \mathrm{br}$ ? 
HNF-2693

Revision 1

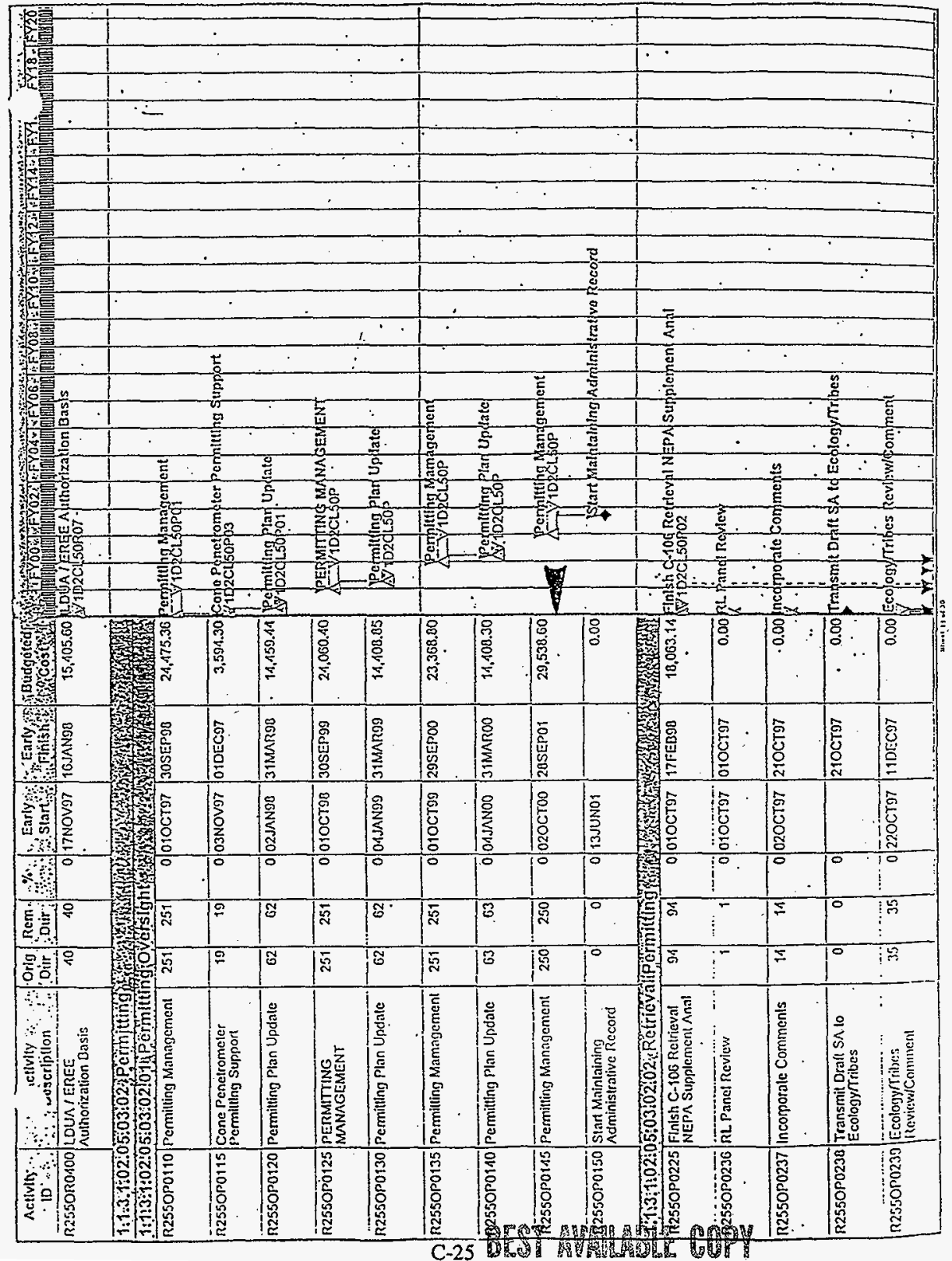


HNF-2693

Revision 1

\section{1. $\quad 1.0 \mathrm{~m}^{3}\left(36 \mathrm{ft}^{3}\right)$ Sluicer Operational Costs}

The estimate for operating the sluicer in tanks $241-\mathrm{AX}-101$ and $241-\mathrm{AX}-103$ is based on the data in tables A-1 through A-5. Estimates are based on operating 7 days per week and 24 hours per day.

AX-101 Operational time $\quad 170.2$ days (24.3 wks)

AX-103 Operational time $\quad 57.4$ days (8.2 wks)

5 person crew X 4 shifts X 40 hrs/wk X 32.5 weeks X $\$ 95 / \mathrm{hr}$

TOTAL

$\$ 2,470,000$

\section{DB\36.OPS}


HNF-2693

Revision 1

\section{2. $\quad 1.0 \mathrm{~m}^{3}\left(36 \mathrm{ft}^{3}\right)$ Vehicle Operational Costs}

For the $1.2 \mathrm{~m}^{3}\left(36 \mathrm{ft}^{3}\right)$ case, the vehicle is used in all four AX farm tanks. The estimate for vehicle operating time is based on the data in tables A-1 through A-5.

$\begin{array}{lc}\text { AX-101 Operational time } & 105.4 \text { days } \\ \text { AX-102 Operational time } & 106.9 \text { days } \\ \text { AX-103 Operational time } & 105.4 \text { days } \\ \text { AX-104 Operational time } & 91.5 \text { days }\end{array}$

Total $\quad 409.2$ days $(58.5 \mathrm{wks})$

The vendor labor costs are based on a 3 man crew, 4 shifts, and a 4 man home office support for 58.5 weeks of retrieval time at each tank (the labor through the ORR is included with in the installation costs).

There are 4 weeks required to move the system from tank to tank.

There are an additional 4 weeks of time required for the dismantling and removal of the retrieval system.

The total time required is:

Retrieve four tanks

Move system 3 times

Dismantle system

TOTAL
58.5 weeks

12 weeks

4 weeks

74.5 weeks

16 persons @ $\$ 75 / \mathrm{hr} X 40 \mathrm{hr} / \mathrm{wk}$ for 74.5 weeks $\$ 3,576,000$

Per diem (12 persons @\$80/day)

$\$ 501,000$

Sub-total $\$ 4,077,000$

PHMC labor costs are for a 6 man crew, four shifts, for the 74.5 weeks retrieval and dismantling time.

24 persons @ $\$ 95 / \mathrm{hr}$ for 74.5 weeks

$\$ 6,794,, 000$

TOTAL

$\$ 10,871,000$

DBI36VEH.OPS 
HNF-2693

Revision 1

This page intentionally left blank. 
HNF-2693

Revision 1

\section{APPENDIX D}

\section{COST AND WORKER-HOUR BREAKDOWN}


HNF-2693

Revision 1

This page intentionally left blank.

D-2 
HNF-2693

Revision 1

\section{APPENDIX D}

\section{COST AND WORKER-HOUR BREAKDOWN}

The summary of the breakdown of the costs and worker-hours for the three levels of residual waste volumes is shown below. The details of the breakdowns are show in the remainder of the appendix. The breakdowns are for the estimates contained in Appendix A. Refer to Appendix A for the estimate basis.

\begin{tabular}{|l|l|l|l|}
\hline & $\begin{array}{l}102 \mathrm{~m}^{3}(3,600 \\
\left.\mathrm{ft}^{3}\right)\end{array}$ & $10.2 \mathrm{~m}^{3}\left(360 \mathrm{ft}^{3}\right)$ & $\begin{array}{l}1.0 \mathrm{~m}^{3}(36 \\
\left.\mathrm{ft}^{3}\right)\end{array}$ \\
\hline Capital Cost & $\$ 29,680,000$ & $\$ 31,157,000$ & $\$ 31,157,000$ \\
\hline PHMC operating cost & $\$ 5,546,000$ & $\$ 9,590,000$ & $\$ 18,489,000$ \\
\hline PHMC operating worker-hours & 38,619 & 66,760 & 128,726 \\
\hline $\begin{array}{l}\text { PHMC installation worker- } \\
\text { hours }\end{array}$ & 241,970 & 325,528 & 325,528 \\
\hline D\&D cost & $\$ 1,008,000$ & $\$ 1,184,000$ & $\$ 1,184,000$ \\
\hline
\end{tabular}

$D \& D=$ Decontamination and decommissioning PHMC = Project Hanford Management Contractor. 
HNF-2693

Revision 1

\section{$102 \mathrm{~m}^{3}\left(3,600 \mathrm{ft}^{3}\right)$ CAPITAL COSTS}

The estimates in this appendix are a breakdown of the costs in Appendix A. Refer to Appendix A for the cost basis.

1. LLCE Removal

From Manderbach (1997a), "Slurry Pump Removal" the cost of a flexible receiver is $\$ 212,000$ and the cost of a metal burial box is $\$ 5,000$. Applying an 8 percent sales tax, the cost of the first unit is $\$ 245,000$. Subsequent units are estimated at 72 percent of the first unit or $\$ 176,000$. Cost for 6 units is $245+$ $.72 \times 5 \times 245$

TOTAL $=\$ 1,075,000$.

2. Sluicing Equipment Fabrication

From FDNW Enhanced Sluicing Estimate E20144, page 2, WBS 15140, the vendor cost is $\$ 2,000,000$ for each tank.

TOTAL $=\$ 4,000,000 . \quad$ (for 2 tanks)

3. Sluicer Control Room

Per Appendix A, the sluicer control room costs $\$ 204,000$. Assume $\$ 95,000$ for the purchase of a Mobile Office.

TOTAL $=\$ 95,000$.

4. Vehicle Retrieval System

Per Appendix A, the vendor procurement cost is $\$ 5.5 \mathrm{M}$. Assume 100 percent capital cost.

TOTAL $=\$ 5,500,000$.

5. HVAC System

From Appendix A, the cost of the HVAC is $\$ 982 \mathrm{k}$ with $\$ 700 \mathrm{k}$ assumed capital costs.

TOTAL $=\$ 700,000$. 
HNF-2693

Revision 1

6. Waste Transfer Line

Per Appendix A, the cost of the waste transfer line is $\$ 910 \mathrm{k}$ based on a vendor fabricate and install contract. Assume 50 percent is capital.

TOTAL $=\$ 455,000$.

7. New Valve Pit

The new pit and cover block design, fabrication, and installation are assumed to be PHMC tasks. Of the total cost, $\$ 50 \mathrm{k}$ is assumed to be capital.

TOTAL $=\$ 50,000$.

8. Pit Decontamination

Assume $\$ 2,000 \mathrm{k}$ for a vendor to design, fabricate, and deliver a pit decontamination system per PHMC specifications.

TOTAL $=\$ 2,000,000$.

9. Balance of Plant

The Jumper fabrication costs are capital expenditures. Per Appendix A, 16 jumpers at $\$ 56 \mathrm{~K}$ each.

TOTAL $=\$ 896,000$.

TOTAL CAPITAL COST $=\$ 14,871,000+$ CONTINGENCY AND ESCALATION $=\$ 29,680,000$.

13600CAP 
HNF-2693

Revision 1

\section{$10.2 \mathrm{~m}^{3}\left(360 \mathrm{ft}^{3}\right)$ CAPITAL COSTS}

The estimates in this appendix are a breakdown of the costs in Appendix A. Refer to Appendix A for the cost basis.

\section{LLCE Removal}

From Manderbach (1997a), "Slurry Pump Removal" the cost of a flexible receiver is $\$ 212,000$ and the cost of a metal burial box is $\$ 5,000$. Applying an 8 percent sales tax, the cost of the first unit is $\$ 245,000$. Subsequent units are estimated at 72 percent of the first unit or $\$ 176,000$. Cost for 9 units is $245+$ $.72 \times 8 \times 245$

TOTAL $=\$ 1,656,000$.

2. Sluicing Equipment Fabrication

From FDNW Enhanced Sluicing Estimate E20144, page 2, WBS 15140, the vendor cost is $\$ 2,000,000$ for each tank.

TOTAL $=\$ 4,000,000$. (for 2 tanks)

3. Sluicer Control Room

Per Appendix A, the sluicer control room costs $\$ 204,000$. Assume $\$ 95,000$ for the purchase of a Mobile Office.

TOTAL $=\$ 95,000$.

4. Vehicle Retrieval System

Per Appendix A, the vendor procurement cost is $\$ 5.5 \mathrm{M}$. Assume 100 percent capital cost.

TOTAL $=\$ 5,500,000$.

5. HVAC System

From Appendix A, the cost of the HVAC is $\$ 982 \mathrm{k}$ with $\$ 700 \mathrm{k}$ assumed capital costs.

TOTAL $=\$ 700,000$. 
HNF-2693

Revision 1

6. Waste Transfer Line

Per Appendix A, the cost of the waste transfer line is $\$ 980 \mathrm{k}$ based on a vendor fabricate and install contract. Assume 50 percent is capital.

TOTAL $=\$ 490,000$.

7. New Valve Pit

The new pit and cover block design, fabrication, and installation are assumed to be PHMC tasks. Of the total cost, $\$ 50 \mathrm{k}$ is assumed to be capital.

TOTAL $=\$ 50,000$.

8. Pit Decontamination

Assume $\$ 2,000 \mathrm{k}$ for a vendor to design, fabricate, and deliver a pit decontamination system per PHMC specifications.

TOTAL $=\$ 2,000,000$.

9. Balance of Plant

The Jumper fabrication costs are capital expenditures. Per Appendix A, 20 jumpers at $\$ 56 \mathrm{~K}$ each.

TOTAL $=\$ 1,120,000$.

TOTAL CAPITAL COST $=\$ 15,611,000+$ CONTINGENCY AND ESCALATION

$=\$ 31,157,000$.

1360CAP 
HNF-2693

Revision 1

\section{$1.0 \mathrm{~m}^{3}\left(36 \mathrm{ft}^{3}\right)$ CAPITAL COSTS}

The estimates in this appendix are a breakdown of the costs in Appendix A. Refer to Appendix A for the cost basis.

\section{LLCE Removal}

From Manderbach (1997a), "Slurry Pump Removal" the cost of a flexible receiver is $\$ 212,000$ and the cost of a metal burial box is $\$ 5,000$. Applying an 8 percent sales tax, the cost of the first unit is $\$ 245,000$. Subsequent units are estimated at 72 percent of the first unit or $\$ 176,000$. Cost for 9 units is $245+$ $.72 \times 8 \times 245$

TOTAL $=\$ 1,656,000$.

2. Sluicing Equipment Fabrication

From FDNW Enhanced Sluicing Estimate E20144, page 2, WBS 15140, the vendor cost is $\$ 2,000,000$ for each tank.

TOTAL $=\$ 4,000,000$. (for 2 tanks)

3. Sluicer Control Room

Per Appendix A, the sluicer control room costs $\$ 204,000$. Assume $\$ 95,000$ for the purchase of a Mobile Office.

TOTAL $=\$ 95,000$.

4. Vehicle Retrieval System

Per Appendix A, the vendor procurement cost is $\$ 5.5 \mathrm{M}$. Assume 100 percent capital cost.

TOTAL $=\$ 5,500,000$.

5. HVAC System

From Appendix A, the cost of the HVAC is $\$ 982 \mathrm{k}$ with $\$ 700 \mathrm{k}$ assumed capital costs.

TOTAL $=\$ 700,000$. 
HNF-2693

Revision 1

6. Waste Transfer Line

Per Appendix A, the cost of the waste transfer line is $\$ 980 \mathrm{k}$ based on a vendor fabricate and install contract. Assume 50 percent is capital.

TOTAL $=\$ 490,000$.

7. New Valve Pit

The new pit and cover block design, fabrication, and installation are assumed to be PHMC tasks. Of the total cost, $\$ 50 \mathrm{k}$ is assumed to be capital.

TOTAL $=\$ 50,000$.

8. Pit Decontamination

Assume $\$ 2,000 \mathrm{k}$ for a vendor to design, fabricate, and deliver a pit decontamination system per PHMC specifications.

TOTAL $=\$ 2,000,000$.

9. Balance of Plant

The Jumper fabrication costs are capital expenditures. Per Appendix A, 20 jumpers at $\$ 56 \mathrm{~K}$ each.

TOTAL $=\$ 1,120,000$.

TOTAL CAPITAL COST $=\$ 15,611,000+$ CONTINGENCY AND ESCALATION $=\$ 31,157,000$.

136CAP 
HNF-2693

Revision 1

\section{PHMC OPERATING COSTS}

Estimates in this appendix are a breakdown of the costs in Appendices A, B, and C. Refer to Appendix A for the cost basis.

$102 \mathrm{~m}^{3}\left(3,600 \mathrm{ft}^{3}\right)$ Residual Waste

Sluicer - 5 person crew X 4 shifts X 31.7 weeks X $40 \mathrm{hr} / \mathrm{wk}$ X $\$ 95 / \mathrm{hr}=\$ 2,409,000$

Vehicle - 6 person crew X 4 shifts X 4.06 weeks X $40 \mathrm{hr} / \mathrm{wk}$ X $\$ 95 / \mathrm{hr}=\$ 370,000$

TOTAL $=\$ 2,779,000+$ contingency (32 percent) and escalation (51.2 percent)

$=\$ 5,546,000$

\section{$10.2 \mathrm{~m}^{3}\left(360 \mathrm{ft}^{3}\right)$ Residual Waste}

Sluicer - 5 person crew X 4 shifts X 32.5 weeks X $40 \mathrm{hr} /$ wk X $\$ 95 / \mathrm{hr}=\$ 2,470,000$

Vehicle - 6 person crew X 4 shifts X 25.6 weeks X 40 hr/wk X $\$ 95 / \mathrm{hr}=\$ 2,335,000$

TOTAL $=\$ 4,805,000+$ contingency and escalation $\quad=\$ 9,540,000$

\section{$1.0 \mathrm{~m}^{3}\left(36 \mathrm{ft}^{3}\right)$ Residual Waste}

Sluicer - 5 person crew X 4 shifts X 32.5 weeks X $40 \mathrm{hr} / \mathrm{wk}$ X $\$ 95 / \mathrm{hr}=\$ 2,470,000$

Vehicle - 6 person crew X 4 shifts X 74.5 weeks X $40 \mathrm{hr} / \mathrm{wk}$ X $\$ 95 / \mathrm{hr}=\$ 6,974,000$

TOTAL $=\$ 9,264,000+$ contingency and escalation $\quad=\$ 18,489,000$

PHMC-OPS 
HNF-2693

Revision 1

\section{PHMC OPERATING WORKER-HOURS}

The estimates in this appendix are a breakdown of the costs in Appendix A. Refer to Appendix A for the cost basis.

$102 \mathrm{~m}^{3}\left(3,600 \mathrm{ft}^{3}\right)$ Residual Waste

Sluicer - 5 person crew X 4 shifts X 31.7 weeks X 40 hr/wk $=25,360$

Vehicle - 6 person crew X 4 shifts X 4.06 weeks X $40 \mathrm{hr} / \mathrm{wk}=.3,897$

TOTAL $=29,257+$ contingency $(32$ percent $) \quad=38,619$

$10.2 \mathrm{~m}^{3}\left(360 \mathrm{ft}^{3}\right)$ Residual Waste

Sluicer - 5 person crew X 4 shifts X 32.5 weeks X $40 \mathrm{hr} / \mathrm{wk} \quad=26,000$

Vehicle - 6 person crew X 4 shifts X 25.6 weeks X 40 hr/wk $=24,576$

TOTAL $=50,576+$ contingency $(32$ percent $) \quad=66,760$

\section{$1.0 \mathrm{~m}^{3}\left(36 \mathrm{ft}^{3}\right)$ Residual Waste}

Sluicer - 5 person crew X 4 shifts $X 32.5$ weeks $X 40 \mathrm{hr} /$ wk $\quad=26,000$

Vehicle - 6 person crew X 4 shifts X 74.5 weeks X 40 hr/wk $=71,520$

TOTAL $=97,520+$ contingency $(32$ percent $) \quad=128,726$

PHMC-MH 
HNF-2693

Revision 1

\section{$102 \mathrm{~m}^{3}\left(3,600 \mathrm{ft}^{3}\right)$ PHMC INSTALLATION WORKER-HOURS}

The estimates in this appendix are a breakdown of the costs in Appendix A. Refer to Appendix A for the basis.

1. LLCE Removal

From Manderbach (1997a), "Slurry Pump Removal" the worker-hours are 3318 for the first unit. Assume subsequent units are 72 percent of the first unit. Worker-hours for 6 units are $(3318+.72 \times 3318 \times 5)$.

TOTAL $=15,262$

2. Sluicing Equipment Fabrication

From FDNW Enhanced Sluicing Estimate E20144, page 2, WBS 152300, the installation cost is $\$ 1,162,000$. Assume 75 percent labor and 25 percent material/other for each of the 2 tanks. Worker-hours are $2 \times .75 \times \$ 1,162,000$ $\div \$ 95 / \mathrm{hr}$

TOTAL $=18,347$ worker-hours (for 2 tanks)

3. Sluicer Control Room

Per Appendix A, the sluicer control room costs $\$ 204,000$. Assume $\$ 90,000$ for installation labor at $\$ 95 / \mathrm{hr}$. Worker-hours are $\$ 90,000 \div \$ 95 / \mathrm{hr}$.

TOTAL $=947$ worker-hours

4. Vehicle Retrieval System

Per Appendix A, the vehicle installation cost is $\$ 842,000$. Assume $\$ 700,000$ installation labor. Worker-hours are $\$ 700,000 \div \$ 95 / \mathrm{hr}$.

TOTAL $=7,368$ worker-hours

5. HVAC System

From Appendix A, the cost of the HVAC is $\$ 982,000$ with $\$ 125,000$ assumed installation labor costs. Worker-hours are $\$ 125,000 \div \$ 95 / \mathrm{hr}$.

TOTAL $=1,315$ worker-hours. 
HNF-2693

Revision 1

6. Waste Transfer Line

Per Appendix A, the fabrication and installation of the waste transfer line is a vendor cost based on a vendor fabricate and install contract.

TOTAL $=$ NA

7. New Valve Pit

The new pit and cover block design, fabrication, and installation are assumed to be PHMC tasks. Of the total $\$ 334,000$ cost, $\$ 220,000$ is assumed to be installation labor cost. Worker-hours are $\$ 220,000 \div \$ 95 / \mathrm{hr}$.

TOTAL $=2,316$ worker-hours

8. Pit Decontamination

Assume 80 percent of the $\$ 13,500,000$ for the pit decontamination task is PHMC labor. Worker-hours are $.8 \times \$ 13,500,000 \div \$ 95 / \mathrm{hr}$.

TOTAL $=113,684$ worker-hours

9. Balance of Plant

Per Appendix A, assume 80 percent of the cover block removal, cover block fabrication, green house set-up, core drill, concrete pads, and CCTV installation are PHMC labor costs. Worker-hours are $.8 \times(\$ 773,000+\$ 820,000+$ $\$ 794,000+\$ 292,000+\$ 24,000+\$ 156,000) \div \$ 95 / \mathrm{hr}$.

TOTAL $=24,073$ worker-hours

TOTAL PHMC INSTALLATION WORKER-HOURS $=183,311+$ CONTINGENCY $(32$ percent)

$$
=241,970
$$

I3600INST 
HNF-2693

Revision 1

\section{$10.2 \mathrm{~m}^{3}\left(360 \mathrm{ft}^{3}\right)$ PHMC INSTALLATION WORKER-HOURS}

The estimates in this appendix are a breakdown of the costs in Appendix A. Refer to Appendix A for the basis.

1. LLCE Removal

From Manderbach (1997a), "Slurry Pump Removal" the worker-hours are 3318 for the first unit. Assume subsequent units are 72 percent of the first unit. Worker-hours for 9 units are $(3318+.72 \times 3318 \times 8)$.

TOTAL $=22,429$

2. Sluicing Equipment Fabrication

From FDNW Enhanced Sluicing Estimate E20144, page 2, WBS 152300, the installation cost is $\$ 1,162,000$. Assume 75 percent labor and 25 percent material/other for each of the 2 tanks. Worker-hours are $2 \times .75 \times \$ 1,162,000$ $\div \$ 95 / \mathrm{hr}$

TOTAL $=18,347$ worker-hours (for 2 tanks)

3. Sluicer Control Room

Per Appendix A, the sluicer control room costs $\$ 204,000$. Assume $\$ 90,000$ for installation labor at $\$ 95 / \mathrm{hr}$. Worker-hours are $\$ 90,000 \div \$ 95 / \mathrm{hr}$.

TOTAL $=947$ worker-hours

4. Vehicle Retrieval System

Per Appendix A, the vehicle installation cost is $\$ 842,000$. Assume $\$ 700,000$ installation labor. The vehicle retrieval system is installed in all four AX farm tanks. Worker-hours are $\$ 700,000 \times 4 \div \$ 95 / \mathrm{hr}$.

TOTAL $=29,474$ worker-hours

5. HVAC System

From Appendix A, the cost of the HVAC is $\$ 982,000$ with $\$ 125,000$ assumed installation labor costs for three tanks. There is an additional $\$ 100,00$ to connect the system to $241-\mathrm{AX}-104$. Worker-hours are $\$ 225,000 \div \$ 95 / \mathrm{hr}$.

TOTAL $=2,368$ worker-hours 
HNF-2693

Revision 1

6. Waste Transfer Line

Per Appendix A, the fabrication and installation of the waste transfer line is a vendor cost based on a vendor fabricate and install contract.

TOTAL $=$ NA

7. New Valve Pit

The new pit and cover block design, fabrication, and installation are assumed to be PHMC tasks. Of the total $\$ 334,000$ cost, $\$ 220,000$ is assumed to be installation labor cost. Worker-hours are $\$ 220,000 \div \$ 95 / \mathrm{hr}$.

TOTAL $=2,316$ worker-hours

8. Pit Decontamination

Assume 80 percent of the $\$ 16,500,000$ for the pit decontamination task is PHMC labor. Worker-hours are $.8 \times \$ 16,500,000 \div \$ 95 / \mathrm{hr}$.

TOTAL $=138,947$ worker-hours

9. Balance of Plant

Per Appendix A, assume 80 percent of the cover block removal, cover block fabrication, green house set-up, core drill, concrete pads, and CCTV installation are PHMC labor costs. Worker-hours are $.8 \times(\$ 928,000+\$ 1,025,000+$ $\$ 953,000+\$ 350,000+\$ 32,000+\$ 208,000) \div \$ 95 / \mathrm{hr}$.

TOTAL $=31,874$ worker-hours

TOTAL PHMC INSTALLATION WORKER-HOURS $=246,612+$ CONTINGENCY (32 percent)

$$
=325,528
$$


HNF-2693

Revision 1

\section{$1.0 \mathrm{~m}^{3}\left(36 \mathrm{ft}^{3}\right)$ PHMC INSTALLATION WORKER-HOURS}

The estimates in this appendix are a breakdown of the costs in Appendix A. Refer to Appendix A for the basis.

1. LLCE Removal

From Manderbach (1997a), "Slurry Pump Removal" the worker-hours are 3318 for the first unit. Assume subsequent units are 72 percent of the first unit. Worker-hours for 9 units are $(3318+.72 \times 3318 \times 8)$.

TOTAL $=22,429$

2. Sluicing Equipment Fabrication

From FDNW Enhanced Sluicing Estimate E20144, page 2, WBS 152300, the installation cost is $\$ 1,162,000$. Assume 75 percent labor and 25 percent material/other for each of the 2 tanks. Worker-hours are $2 \times .75 \times \$ 1,162,000$ $\div \$ 95 / \mathrm{hr}$

TOTAL $=18,347$ worker-hours (for 2 tanks)

3. Sluicer Control Room

Per Appendix A, the sluicer control room costs $\$ 204,000$. Assume $\$ 90,000$ for installation.labor at $\$ 95 / \mathrm{hr}$. Worker-hours are $\$ 90,000 \div \$ 95 / \mathrm{hr}$.

TOTAL $=947$ worker-hours

4. Vehicle Retrieval System

Per Appendix A, the vehicle installation cost is $\$ 842,000$. Assume $\$ 700,000$ installation labor. The vehicle retrieval system is installed in all four $\mathrm{AX}$ farm tanks. Worker-hours are $\$ 700,000 \times 4 \div \$ 95 / \mathrm{hr}$.

TOTAL $=29,474$ worker-hours

\section{HVAC System}

From Appendix A, the cost of the HVAC is $\$ 982,000$ with $\$ 125,000$ assumed installation labor costs for three tanks. There is an additional $\$ 100,00$ to connect the system to $241-\mathrm{AX}-104$. Worker-hours are $\$ 225,000 \div \$ 95 / \mathrm{hr}$.

TOTAL $=2,368$ worker-hours 
HNF-2693

Revision 1

6. Waste Transfer Line

Per Appendix A, the fabrication and installation of the waste transfer line is a vendor cost based on a vendor fabricate and install contract.

TOTAL $=$ NA

7. New Valve Pit

The new pit and cover block design, fabrication, and installation are assumed to be PHMC tasks. Of the total $\$ 334,000$ cost, $\$ 220,000$ is assumed to be installation labor cost. Worker-hours are $\$ 220,000 \div \$ 95 / \mathrm{hr}$.

TOTAL $=2,316$ worker-hours

8. Pit Decontamination

Assume 80 percent of the $\$ 16,500,000$ for the pit decontamination task is PHMC labor. Worker-hours are $.8 \times \$ 16,500,000 \div \$ 95 / \mathrm{hr}$.

TOTAL $=138,947$ worker-hours

9. Balance of Plant

Per Appendix A, assume 80 percent of the cover block removal, cover block fabrication, green house set-up, core drill, concrete pads, and CCTV installation are PHMC labor costs. Worker-hours are $.8 \times(\$ 928,000+\$ 1,025,000+$ $\$ 953,000+\$ 350,000+\$ 32,000+\$ 208,000) \div \$ 95 / \mathrm{hr}$.

TOTAL $=31,874$ worker-hours

TOTAL PHMC INSTALLATION WORKER-HOURS $=246,612$

+ CONTINGENCY (32 PERCENT) $\quad=325,528$

I36INST 
HNF-2693

Revision 1

\section{DECONTAMINATION AND DECOMMISSIONING COSTS}

The estimates in this appendix are a breakdown of the costs in Appendix A. Refer to Appendix A for the cost basis.

$102 \mathrm{~m}^{3}\left(3,600 \mathrm{ft}^{3}\right)$ Residual Waste

Vehicle Procurement - The $\$ 5.5 \mathrm{M}$ vendor cost for a vehicle retrieval system includes $\$ 100 \mathrm{k}$ for D\&D.

BOP Mods And Installation - The pump disposal ( $\$ 55 \mathrm{~K})$ and the cover block disposal $(\$ 350 \mathrm{k})$ are $\mathrm{D} \& \mathrm{D}$ costs.

$$
\begin{aligned}
\text { TOTAL } & =\$ 100 \mathrm{k}+\$ 55 \mathrm{k}+\$ 350 \mathrm{~K} \\
& =\$ 505,000 .+ \text { contingency }(32 \text { percent) and escalation. } \\
= & \$ 1,008,000 .
\end{aligned}
$$

$360 \mathrm{Ft}^{3}$ Residual Waste

Vehicle Procurement - The $\$ 5.5 \mathrm{M}$ vendor cost for a vehicle retrieval system includes $\$ 100 \mathrm{k}$ for D\&D.

BOP Mods And Installation - The pump disposal (\$55K) and the cover block disposal (\$438k) D\&D costs.

$$
\begin{aligned}
\text { TOTAL } & =\$ 100 \mathrm{k}+\$ 55 \mathrm{k}+\$ 438 \mathrm{~K} \\
& =\$ 593,000+\text { contingency and escalation } \\
& =\$ 1,184,000 .
\end{aligned}
$$

\section{$36 \mathrm{Ft}^{3}$ Residual Waste}

Vehicle Procurement - The $\$ 5.5 \mathrm{M}$ vendor cost for a vehicle retrieval system includes $\$ 100 \mathrm{k}$ for D\&D. 
HNF-2693

Revision 1

BOP Mods And Installation - The pump disposal (\$55K) and the cover block disposal (\$438k) D\&D costs.

$$
\begin{aligned}
\text { TOTAL } & =\$ 100 \mathrm{k}+\$ 55 \mathrm{k}+\$ 438 \mathrm{~K} \\
& =\$ 593,000+\text { contingency and escalation } \\
& =\$ 1,184,000
\end{aligned}
$$

$\backslash \mathrm{D} \& \mathrm{D}$ 
HNF-2693

Revision 1

This page intentionally left blank. 
HNF-2693

Revision 1

\section{APPENDIX E}

\section{MISCELLANEOUS INFORMATION}


HNF-2693

Revision 1

This page intentionally left blank.

E-2 
HNF-2693

Revision 1

APPENDIX E

MISCELLANEOUS AX TANK FARM INFORMATION

\begin{tabular}{|c|l|l|l|}
\hline \multicolumn{1}{|c|}{ Tank } & \multicolumn{1}{|c|}{ Current volume } & \multicolumn{1}{c|}{ Waste depth } & Condition \\
\hline $241-\mathrm{AX}-101$ & $2,838,750 \mathrm{~L}(750,000 \mathrm{gal})$ & $6.7 \mathrm{~m}(22 \mathrm{ft})$ deep & Sound \\
\hline $241-\mathrm{AX}-102$ & $124,905 \mathrm{~L}(33,000 \mathrm{gal})$ & $30 \mathrm{~cm}(12 \mathrm{in}$.$) deep$ & Leaker \\
\hline $241-\mathrm{AX}-103$ & $423,920 \mathrm{~L}(112,000 \mathrm{gal})$ & $102 \mathrm{~cm}(40 \mathrm{in}$.$) deep$ & Sound \\
\hline $241-\mathrm{AX}-104$ & $26,495 \mathrm{~L}(7,000 \mathrm{gal})$ & $6 \mathrm{~cm}(2.5$ in. $)$ deep & Leaker \\
\hline
\end{tabular}

\begin{tabular}{|c|c|c|}
\hline Tank & \multicolumn{1}{|c|}{ Sluicing heel } & Years sluiced \\
\hline $241-\mathrm{AX}-101$ & $11,355 \mathrm{~L}(3,000 \mathrm{gal})$ & $1975 / 76$ \\
\hline $241-\mathrm{AX}-102$ & $26,495 \mathrm{~L}(7,000 \mathrm{gal})$ & $1976 / 77$ \\
\hline $241-\mathrm{AX}-103$ & $62,452 \mathrm{~L}(16,500 \mathrm{gal})$ & $1976 / 77$ \\
\hline $241-\mathrm{AX}-104$ & $26,495 \mathrm{~L}(7,000 \mathrm{gal})$ & $1976 / 78$ \\
\hline
\end{tabular}

(Becker [1997] used as source of sluicing heel volumes)

Note that the residual sluicing heel achieved in the 1970 's (using 2 sluicers) exceeded $10.2 \mathrm{~m}^{3}$ $\left(360 \mathrm{ft}^{3}\right)$ in all four tanks.

\section{SHADOWS}

There are 22 ALCs in the AX farm tanks. These are full length pipes $76 \mathrm{~cm}(30-\mathrm{in}$.) in diameter. These "shadow" a significant portion of the tank volume from the sluicing jet.

\section{OTHER}

Tank liner height $9.9 \mathrm{~m}(32 \mathrm{ft}-6 \mathrm{in}$.

Flat bottom tanks

There is no active ventilation system in AX farm. 
HNF-2693

Revision 1

\section{TELECON MEMO}

DATE: $4 / 30 / 98$

TIME:

SUBJECT: Techniques for measuring waste in the SSTs

\section{BETWEEN: S. A. Krieg/F. R. Reich}

General discussion on the techniques and capabilities of the various systems for measuring the remaining waste in the SSTs are documented as follows:

- There are two technologies that are sufficiently developed to use for waste volume measurements, video and photogrammetry.

- The best waste volume measurement we can expect with video or photogrammetry is $360 \mathrm{ft}^{3} \pm 180 \mathrm{ft}^{3}$.

- A third technology, Topographic Mapping System (TMS), aka structured light, has the potential to measure $180 \mathrm{ft}^{3} \pm 90 \mathrm{ft}^{3}$ of residual waste but needs development.

- It is not feasible to measure $36 \mathrm{ft}^{3}$ of waste remaining in a SST with any of the current technologies.

- All three of the current waste measurement technologies (video, photogrammetry, TMS) are surface measurement tools - accuracies depend on locating the tank walls, floor, etc.

- $\quad$ Accuracies depend on the surface contour of the waste. Less accurate measurements are obtained on rough waste surfaces than smooth ones.

- None of the three systems are able to differentiate between waste and corrosion products i.e. waste looks like rust on the surface of the tank.

- In the AX farm tanks there is a problem with the air lift circulators (ALC). The systems are unable to "see" the back of the ALCs, inside the ALCs, or the wall area in the "shadow" of the ALCs.

Fred will send me a copy of the handouts from the "HTI Waste Volume Estimate Review" of April, 1997. These handouts have a considerable amount of information that was developed by the Waste Volume Estimate Team (Fred Reich, Mike Sumsion, Dennis Goodnough, and Don Daly).

\section{S. A. KRIEG}




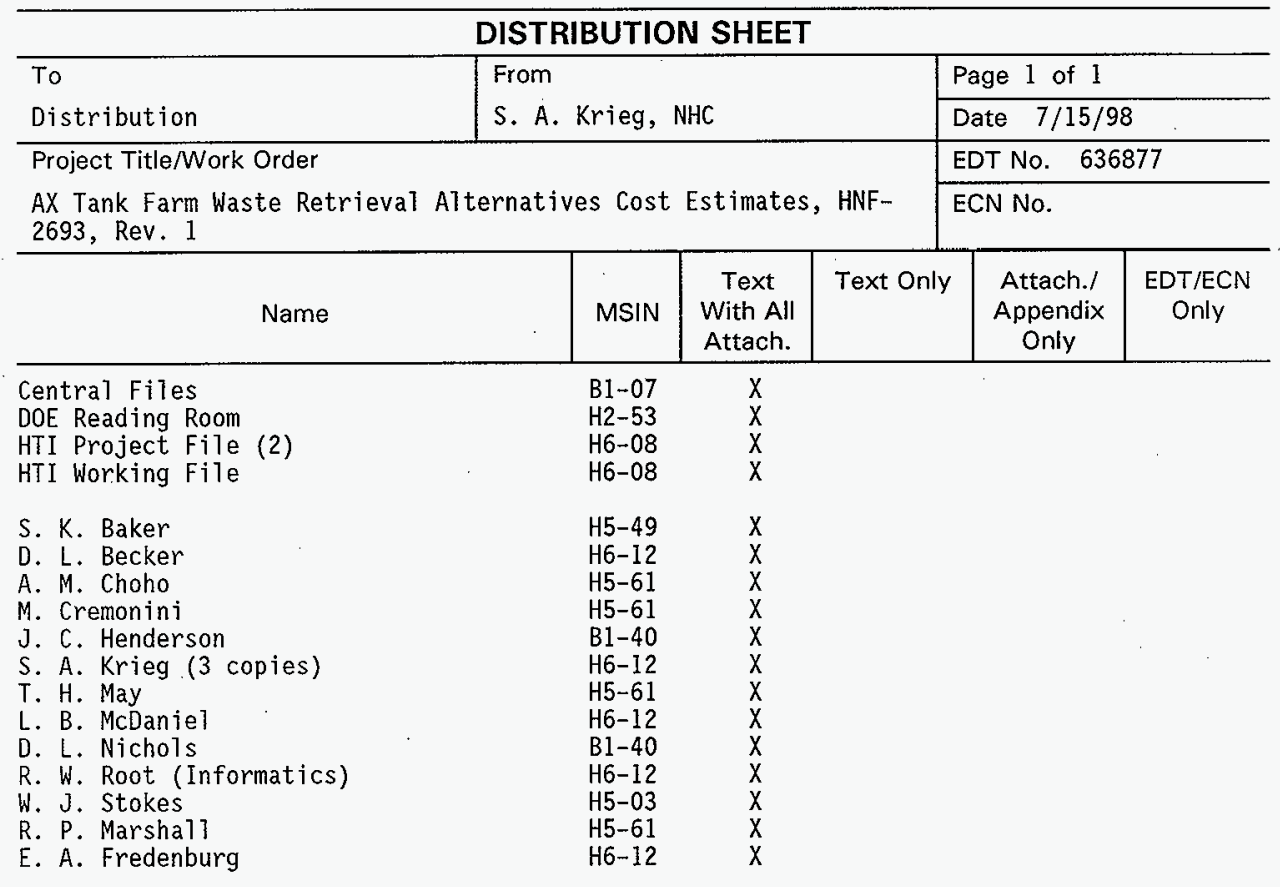

